\title{
ipen
}

INSTITUTO DE PESQUISAS ENERGÉTICAS E NUCLEARES

AUTARQUIA ASSOCIADA À UNIVERSIDADE DE SÃO PAULO

\section{AVALIAÇÃO DE TOXICIDADE AGUDA E CRÔNICA EM ÁGUAS DO RIO JUNDIAÍ E EM AFLUENTES E EFLUENTES DA ETE NOVO HORIZONTE, JUNDIAÍ, SÃO PAULO}

\author{
ANTONIO CARLOS NOGUEIRA NETO
}

Dissertação apresentada como parte dos requisitos para obtenção do Grau de Mestre em Ciências na Área de Tecnologia Nuclear - Aplicações.

Orientadora: Dra. Sueli Ivone Borrely

SÃO PAULO 


\section{AGRADECIMENTOS}

Primeiramente a minha orientadora Sueli Ivone Borrely pela oportunidade de ingressar no mestrado, pelas orientações que realmente contribuíram para o sucesso do meu trabalho, pelas broncas e pelas cobranças feitas; sem ela este trabalho não teria acontecido.

Ao Instituto de Pesquisas Energéticas e Nucleares pela oportunidade e pelo apoio na realização do trabalho.

Ao DAE Jundiaí S.A. pela parceria e oportunidade de realizar um trabalho pioneiro na cidade e também pela ajuda na coleta dos materiais.

A todos os funcionários do Centro de Tecnologia das radiações do Ipen, e a todos os alunos da Sueli (Marcela, Natalia, Renata, Vanessa, Letícia, Rebeca, Alessandro, Gabriel, Dymes).

À bióloga Maria Elisabete Mendes Lopes Botan, por todo apoio dado ao trabalho e pelos dados fornecidos.

A todos meus familiares principalmente ao meu pai ,Antonio Carlos Nogueira Junior e minha mãe, Edna de Fátima Della Guardia por todas as forças que me deram pra que eu nunca desistisse dos meus objetivos. Não posso esquecer também de citar meus falecidos avós; Antonio Carlos Nogueira, quem não tive a oportunidade de conhecer e Theresinha Morelatto Della Guardia que com certeza estariam orgulhosos. E por ultimo Elvira Marques Nogueira e Antonio João Della Guardia, meus avós presentes.

Quero prestar uma homenagem especial aos amigos do Q.G. do C.C, que muito me apoiaram durante o mestrado, ajudando a relaxar nos momentos de tensão. Existe algo inexplicável nessa amizade.

Aos meus amigos de 13 a 70 anos, pelas animadas sextas-feiras na casa do Flavio, pelas saideiras e sempre construtivas conversas, além de todo o apoio que me dedicaram.

Por final tenho muita a agradecer à minha noiva e advogada pelo apoio, compreensão, por acreditar que estou seguindo o caminho correto e também pela ajuda com as leis. Te Amo! 


\title{
Avaliação de toxicidade aguda e crônica em águas do Rio Jundiaí, e em afluentes e efluentes da ETE Novo Horizonte, Jundiaí, São Paulo
}

\section{Antonio Carlos Nogueira Neto}

\begin{abstract}
Resumo
A cidade de Jundiaí está localizada a aproximadamente $60 \mathrm{Km}$ de São Paulo e tem uma população de 342.983 mil habitantes sendo que $94,37 \%$ residem na zona urbana. A cidade está inserida na bacia hidrográfica do Rio Jundiaí, rio que é formado a partir da confluência do Rio Jundiaizinho com o Ribeirão das Taipas e possui uma extensão de 123 quilômetros e sua foz está situada em Salto, na confluência do Rio Jundiaí com o Rio Tietê. Está é menor bacia hidrográfica do estado de São Paulo e também uma das mais industrializadas. A cidade de Jundiaí conta com a Estação de Tratamento de Esgotos Novo Horizonte (ETE Jundiaí), que coleta 98\% dos esgotos da cidade, trata $100 \%$ de todo esgoto coletado, com eficiência de remoção de $92 \%$ de carga orgânica, esgoto que depois do tratamento é lançado no Rio Jundiaí. O objetivo deste trabalho foi utilizar ensaios de toxicidade com organismos aquáticos para avaliar a carga tóxica que chega à ETE, bem como a eficiência do tratamento biológico e a influência da estação no seu entorno. Foram coletadas amostras em 6 pontos distintos; à montante da ETE (P1), na entrada da ETE (P2), na calha de distribuição das lagoas de aeração (P3), nas 2 saídas da ETE (P4 e P5) e à jusante da ETE (P6). As amostras de afluente da ETE foram mais tóxicas que os efluentes da ETE; já os resultados das amostras do rio não apresentaram diferença. Para Vibrio fischeri os valores de CE(i)50 variaram entre 2,23\% e 9,39\% para a calha de entrada das lagoas de aeração, enquanto que para Daphnia similis variaram entre $15,52 \%$ e $89,95 \%$; para a entrada da ETE os valores variaram entre $4,63 \%$ e $8,31 \%$ para Vibrio fischeri , e $17,68 \%$ e não tóxico para Daphnia similis. Nas campanhas onde foram amostradas as saídas da ETE e águas do rio, os ensaios realizados com Vibrio fischeri apresentaram resultados entre $53,55 \%$ e não tóxico para águas do rio e $29,46 \%$ e não tóxico para o efluente da ETE, já para Daphnia similis, os resultados estão entre $55,92 \%$ e não tóxico para águas do rio e $70,97 \%$ e não tóxico para o efluente da ETE. Nos ensaios realizados com Ceriodaphnia dubia, a média de nascimentos para águas do rio esteve entre 4,60 e 15,00 enquanto que para o efluente da ETE esteve entre 4,50 e 10,35 para amostra bruta. Os resultados de toxicidade comprovam a eficiência da ETE na remoção de toxicidade porém outros parâmetros devem ser observados para se comprovar o impacto de seus efluentes sobre as águas do rio.
\end{abstract}




\title{
Acute and chronic toxicity evaluation at Jundiaí river, influent and effluent from Novo Horizonte Wastewater Treatment Plant (NHWWP), Jundiaí, São Paulo
}

\section{Antonio Carlos Nogueira Neto}

\begin{abstract}
Jundiaí is located approximately 60 kilometers from São Paulo and has a population of 342,983 habitants which $94.37 \%$ lives in urban areas. Jundiaí is included in the Jundiaí River basin witch is formed from the confluence of River Jundiaizinho with Ribeirão das Taipas, it has a length of 123 kilometers and its mouth is located in Salto, at the confluence of Jundiaí River with Tietê River. This is the smaller basin of the state and also one of the most industrialized. Jundiaí has the Novo Horizonte Wastewater Treatment Plant (NHWWP) which collects $98 \%$ of the city sewage, and treats $100 \%$ of it, with the removal of organic load efficiency $92 \%$, which waste is drainage in Jundiaí River. The present work used toxicity tests with aquatic organisms to assess the toxic effect that comes form the station, the efficiency of biological treatment, and the influence of the station on its surroundings. Samples were collected at 6 different points, the upstream of NHWWP (P1), the entry of NHWWP (P2), in the pipeline for distribution to the aeration lagoons (P3), in the 2 outputs (P4 and P5) and downstream of NHWWP (P6). The samples of the influents were more toxic than the effluent of NHWWP and the results from the river samples did not show difference. The effective toxic concentrations EC 50 ranged between $2.23 \%$ and $9.39 \%$ for Vibrio fischeri on the pipeline entry to and lagoons, and varied between $15.52 \%$ and $89.95 \%$ for Daphnia similis, for the NHWWP enter the values ranged between $4.63 \%$ and $8.31 \%$ for Vibrio fischeri, and $17.68 \%$ and not toxic to Daphnia similis. In campaigns where sampled the outputs of NHWWP and river waters, the tests with Vibrio fischeri performed between $53.55 \%$ and not toxic to the river water and $29.46 \%$ and not toxic to the effluent of NHWWP, for while to Daphnia similis, the results were between $55.92 \%$ and not toxic to the river water and $70.97 \%$ and not toxic to the effluent of ETE. In tests conducted with Ceriodaphnia dubia, the average of births for the river water was between 4.60 and 15.00 while for the effluent of NHWWP was between 4.50 and 10.35 for crude sample. The results show the efficiency of NHWWP in the removal of toxicity but other parameters should be observed to demonstrate the impact of their effluents on the River waters.
\end{abstract}




\section{SUMÁRIO}

1 INTRODUÇÃO

1.1Bacia Hidrográfica do Rio Jundiaí.................................................................11

2 REVISÃO BIBLIOGRÁFICA …….............................................................

2.1 Tratamento de Esgotos........................................................................... 16

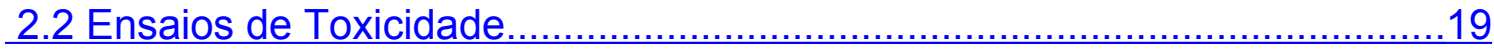

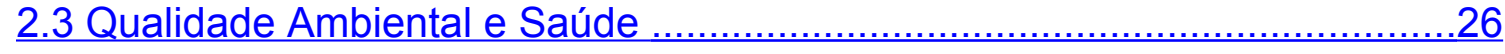

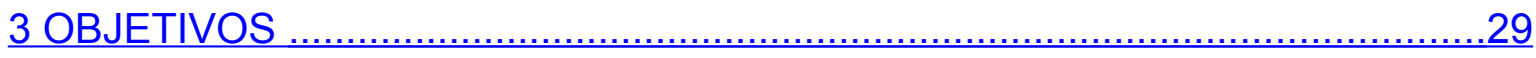

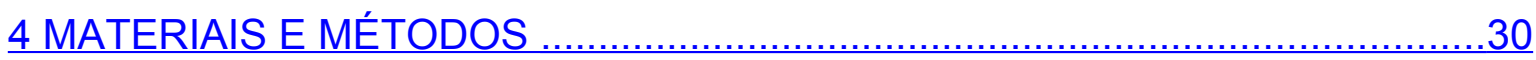

4.1 ETE Novo Horizonte, Jundiaí, São Paulo.................................................30

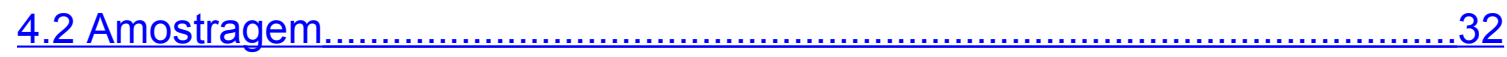

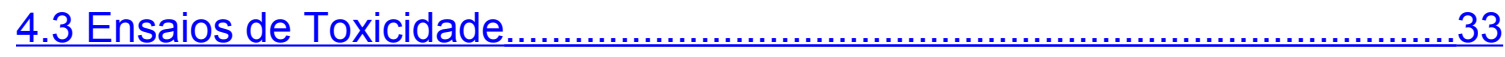

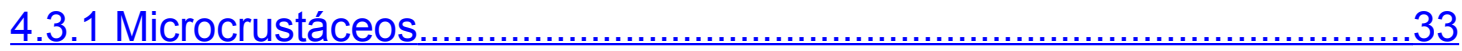

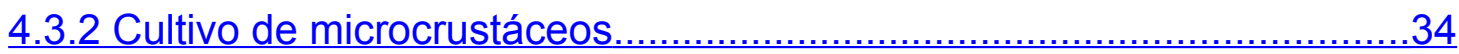

4.3.3 - Ensaios de Toxicidade crônica com Ceriodaphnia dubia.....................36

4.3.4 Ensaios de Toxicidade aguda com Daphnia similis.............................37

4.3.5 - Ensaios de toxicidade aguda com bactérias Vibrio fischeri.................39

4.3.6 Avaliação de Parâmetros Físico - químicos.............................................41

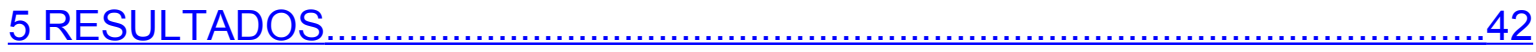

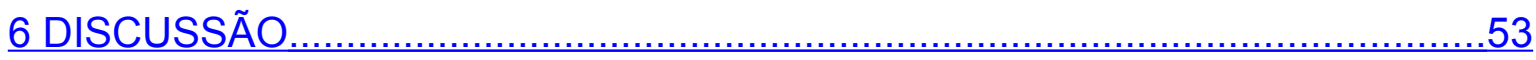

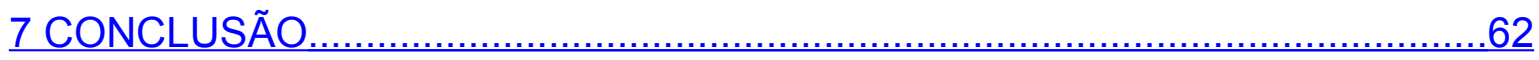

8 ANEXOS

9 REFERÊNCIAS BIBLIOGRÁFICAS …………………....................................69 


\section{LISTA DE TABELAS}

Tabela 1 - Pontos de coleta, localização e tipo de amostras coletadas............................33

Tabela 2 - Médias de nascimento para Ceriodaphnia dubia exposta ao $\mathrm{KCl}$...................37

Tabela 3 - Resultados de toxicidade aguda em afluentes da ETE e da mistura destes com os industriais.

Tabela 4 - Valores de CE(i)50 obtidos com Vibrio fischeri (exposição de 15 min.) em amostras de água do rio e efluente final.

Tabela 5 - Valores de CE(i)50 obtidos com Daphnia similis para exposição em 24 e 48 horas, em amostras de água do rio e efluente final.

Tabela 6 - Média de nascimentos de Ceriodaphnia dubia exposta a águas do Rio Jundiaí e efluentes tratados.

Tabela 7 - Nitrogênio total em águas residuárias $(\mathrm{mg} / \mathrm{l})$

Tabela 8 - Resíduos sólidos totais em águas residuárias (mg/l).

Tabela 9 - Médias mensais de DBO e DQO (ton/dia).

Tabela 10 - Volume de efluente e concentração média de DBO e DQO dos Efluentes industriais (EVCs).

Tabela 11 - Temperatura, pH e condutividade das amostras de água do rio e das saídas da ETE medidos na hora das coletas entre as campanhas 1 e 4 .

Tabela 12 - Temperatura, $\mathrm{pH}$ e condutividade das amostras (P3) aferidos na hora das coletas da campanha 5 .

Tabela 13 - Tipos de EVC e cargas descarregadas no dia 25/03/2008

Tabela 14 - Médias anuais de DBO e DQO na entrada e saída da ETE (em toneladas)......

Tabela 15 - Médias anuais de OD, DBO e DQO no rio Jundiaí, segundo a CETESB.

Tabela 16 - Médias anuais de OD, DBO, DQO em pontos a montante e jusante da ETE... 


\section{LISTA DE FIGURAS}

Figura 1 - Divisão de bacias hidrográficas do estado de São Paulo.

Figura 2 - Mapa da bacia do rio Jundiaí (nascente até foz). Fonte: CETESB, 2009.

Figura 3 - Enquadramento dos rios da bacia do Rio Jundiaí e localização dos pontos de monitoramento da CETESB

Figura 4 - Níveis de efeito biológico dos contaminantes e sua relevância ecológica.

Tabela 5 - Valores de CE(i)50 obtidos com Daphnia similis para exposição em 24 e 48 horas, em amostras de água do rio e efluente final.

Figura 6 - Croqui da Estação de Tratamento de Esgoto de Jundiaí. 32

Figura 7 - Pontos de coleta P1 e P6 (montante e jusante da ETE). .33

Figura 8 - Daphnia similis .34

Figura 9 - Ceriodaphnia dubia.

Figura 10 - Incubadoras e cristalizadores utilizados no cultivo de organismos......35

Figura 11 - Ensaio de Toxicidade crônica com Ceriodaphnia dubia 37

Figura 12 - Carta controle de sensibilidade de D. similis ao $\mathrm{KCl}$. 39

Figura 13 - Carta controle de sensibilidade de V. fischeri ao fenol .40

Figura 14 - Sistema Microtox $®$, modelo M-500 da Microbics.

Figura 15 - Valores de CE(i)50 obtidos com Vibrio fischeri e Daphnia similis em afluentes (amostra composta).

Figura 16 - Valores de CE(i)50 obtidos com Vibrio fischeri e Daphnia similis em mistura de afluentes (emissário + industrial (EVCs))

Figura 17 - média de nascimento de C. dubia em amostras de água do rio e efluente final. 


\begin{abstract}
ANEXOS
Anexo 1 - Dados brutos dos ensaios de Ceriodaphnia dubia na campanha 2....64

Anexo 2 - Dados brutos dos ensaios de Ceriodaphnia dubia na campanha 3.....65

Anexo 3 - Dados brutos dos ensaios de Ceriodaphnia dubia na campanha 4.....66
\end{abstract}




\section{INTRODUÇÃO}

É consenso que o meio ambiente está sendo explorado em demasia pelo homem e com referência às águas, a relação entre consumo e autodepuração está cada vez mais desbalanceada, trazendo graves conseqüências à própria humanidade e ao planeta.

Apesar da água ser um importante recurso para a vida, ela continua sendo degradada. No caso da poluição atmosférica, as chuvas trazem poluentes que contaminam as águas e o solo. A poluição do solo, por sua vez, pode contaminar os lençóis freáticos e as águas dos rios.

Contudo, o maior agravante da poluição da água é o lançamento de esgotos e efluentes industriais aos corpos receptores, algumas vezes após o tratamento e outras, sem o devido tratamento.

Assim como os outros seres vivos, o homem precisa de alimentos, abrigo e, para isso, depende de fontes de energia, como a luz e o calor do sol, ar, água e alimentos. O homem é o único ser capaz de transformar o meio natural para seu próprio benefício, porém essas modificações causaram desequilíbrios ecológicos (Carvalho, 2008). A poluição compromete a saúde, a segurança e o bem estar da população, criando condições adversas às atividades sociais e econômicas e causando danos relevantes à flora, à fauna e ao meio ambiente (SABESP, 2009).

A qualidade de vida dos seres humanos está diretamente ligada à disponibilidade e à qualidade da água, que é utilizada para o funcionamento adequado do organismo, preparo de alimentos, higiene de pessoas e de utensílios. A água usada para abastecimento doméstico deve apresentar características sanitárias e toxicológicas adequadas, isenta de organismos patogênicos e de substâncias tóxicas, para prevenir danos à saúde e favorecer o bem estar das pessoas. Dentre os organismos patogênicos veiculados pela águas encontram-se as bactérias, vírus, parasitas intestinais e protozoários, além das algas tóxicas, cada vez mais freqüentes nos mananciais (Uniágua, 2006).

Em seu estado natural, como se apresenta nos rios, lagos e lençóis subterrâneos, a água contém resíduos das substâncias presentes no ambiente, 
como sais dissolvidos, partículas em suspensão e microrganismos, além de muitos constituintes de matéria orgânica das mais variadas origens. As tecnologias de tratamento de águas visam à eliminação máxima dos poluentes e de agentes que ameaçam a saúde (Borrely, 1995). Por outro lado é necessário o controle de efluentes nos corpos receptores (rios, lagos, mar) e, principalmente, implementar mais tratamento com melhor tecnologia para esgotos e efluentes.

Dentre as fontes de poluição para o ambiente aquático encontram-se descargas diretas e indiretas de efluentes industriais; atividades agrícolas que utilizam indiscriminadamente fertilizantes e produtos agroquímicos, contaminando água, solo e lençóis freáticos; lixo urbano mal acondicionado e espalhado de modo que atinja os córregos e rios; os efluentes domésticos tratados nas estações de tratamento, entre outras (Borrely, 2001; Brito-Pelegrini et. al., 2005). Os esgotos, mesmo que tratados, representam um aporte importante de matéria orgânica no rio, e/ou a contaminação microbiológica (Branco, 1986). Além desses poluentes, pode ocorrer a introdução de outros contaminantes igualmente importantes, tais como metais, radionuclídeos, surfactantes, fármacos, corantes etc.

Outra conseqüência do lançamento de efluentes domésticos e industriais nos ecossistemas aquáticos é a ocorrência de acelerados processos de eutrofização, causando um enriquecimento artificial desses ecossistemas pelo aumento das concentrações de nutrientes na água, principalmente compostos nitrogenados e fosfatos, que resulta num aumento dos processos naturais da produção biológica em rios, lagos e reservatórios, e causa queda de oxigênio dissolvido (OD) na água prejudicando a vida aquática do corpo hídrico afetado pelos poluentes (FUNASA, 2003).

As estações de tratamento de esgoto não são planejadas para degradar plenamente os efluentes industriais. Visando à proteção das águas, diferentes iniciativas bem como recomendações legais têm sido propostas: a Resolução $n^{\circ} 357$, do Conselho Nacional do Meio Ambiente, prevê a melhoria da qualidade dos ambientes aquáticos e recomenda o controle ecotoxicológico, além de apresentar padrões de qualidade das águas e regulamentar o lançamento de efluentes em corpos d'água. Efeito crônico nos rios não deve ser induzido após os lançamentos de efluentes. 
A demanda bioquímica de oxigênio (DBO) ainda é um dos parâmetros principais no controle de poluição de águas por matéria orgânica, representa a quantidade de oxigênio necessária para oxidar a matéria orgânica por decomposição microbiana aeróbia. (Piveli, 2006). Em decorrência dela, pode refletir na condição de oxigenação dos rios. Hoje, outras abordagens são recomendadas, tanto para controle das emissões como no monitoramento ambiental.

O rio Jundiaí é bastante degradado desde as cidades a montante de Jundiaí e, como parte do processo de despoluição do rio, foi construída a Estação de Tratamento de Esgotos de Jundiaí (ETE Novo Horizonte). Para o controle de emissão, monitoramento das águas do rio e avaliação da eficiência da ETE, são realizados pela Companhia de Saneamento de Jundiaí (CSJ) e pelo DAE Esgotos S/A (DAE) ensaios físico-químicos.

O trabalho aqui proposto teve a intenção de complementar esse monitoramento, introduzindo estudos com ensaios ecotoxicológicos, que permitiram avaliar a eficiência da ETE, bem como seu impacto no rio Jundiaí.

\subsection{Bacia Hidrográfica do Rio Jundiaí}

Bacia hidrográfica é a unidade biogeofisiográfica que drena para o rio, lago, represa ou oceano. O conceito de bacia hidrográfica como unidade de pesquisa, gerenciamento e aplicação das informações básicas, é resultado de longa evolução iniciada praticamente com o conceito de carga por Vollenweider e consolidado com os estudos de Likens (1992) demonstrando os experimentos e o trabalho de longa duração no Hubbard-Brook, uma pequena bacia hidrográfica situada nos Estados Unidos. (Tundisi, 2008)

A CETESB iniciou em 1974 a operação da Rede de Monitoramento de Qualidade das Águas Interiores do Estado de São Paulo. As informações obtidas por meio do monitoramento tem possibilitado o conhecimento das condições reinantes nos principais rios e reservatórios situados nas 22 Unidades de Gerenciamento de Recursos Hídricos (UGRHIs) conforme apresentado na figura 1, em que se divide o Estado de São Paulo de acordo com a Lei Estadual n. ${ }^{\circ}$ 
9.034 de 27 de dezembro de 1994. A UGRHI está estruturada no conceito de bacia hidrográfica, onde os tais recursos hídricos convergem para um corpo d'água principal. (CETESB, 2009). Na figura 1, a região em destaque compreende a UGRHI 5 dos rios Piracicaba, Jundiaí e Capivari.

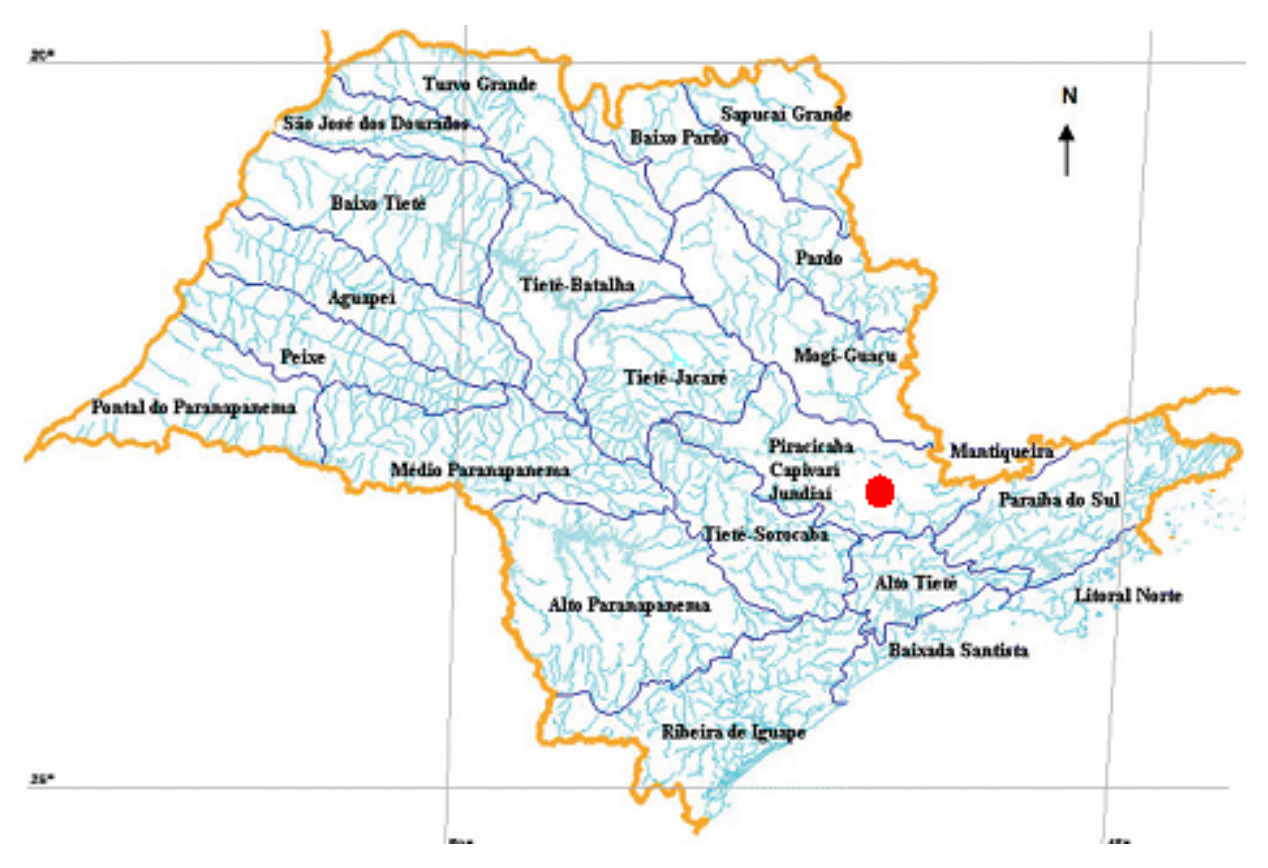

Fonte - Tundisi, 2008.

Figura 1 - Divisão de bacias hidrográficas do estado de São Paulo

A Bacia do Rio Jundiaí, está inserida na Unidade de Gerenciamento de Recursos Hídricos dos Rios Piracicaba, Capivari e Jundiaí, UGRHI - PCJ. Esta bacia compreende os municípios de Campo Limpo Paulista, Várzea Paulista, Jundiaí, Itupeva, Indaiatuba e Salto conforme figura 2 (Gramolelli et. al., 2006).

O Rio Jundiaí, formado a partir da confluência do Rio Jundiaizinho com o Ribeirão das Taipas, possui uma extensão de 123 quilômetros. Suas nascentes mais distantes estão na região serrana de Mairiporã, na Serra da Pedra Vermelha, e sua foz está situada em Salto, na confluência do Rio Jundiaí com o Rio Tietê.

Situada a $60 \mathrm{~km}$ de São Paulo, a cidade de Jundiaí tem uma população de 342.983 mil habitantes sendo que $94,37 \%$ residem na zona urbana (IBGE, 2007). A taxa de mortalidade infantil é de 11,20 por mil nascimentos. A cidade está inserida na bacia hidrográfica do Rio Jundiaí e coleta $98 \%$ dos esgotos da 
cidade, trata $100 \%$ de todo esgoto coletado, com eficiência de remoção de $92 \%$ de carga orgânica o esgoto final é lançado no Rio Jundiaí.

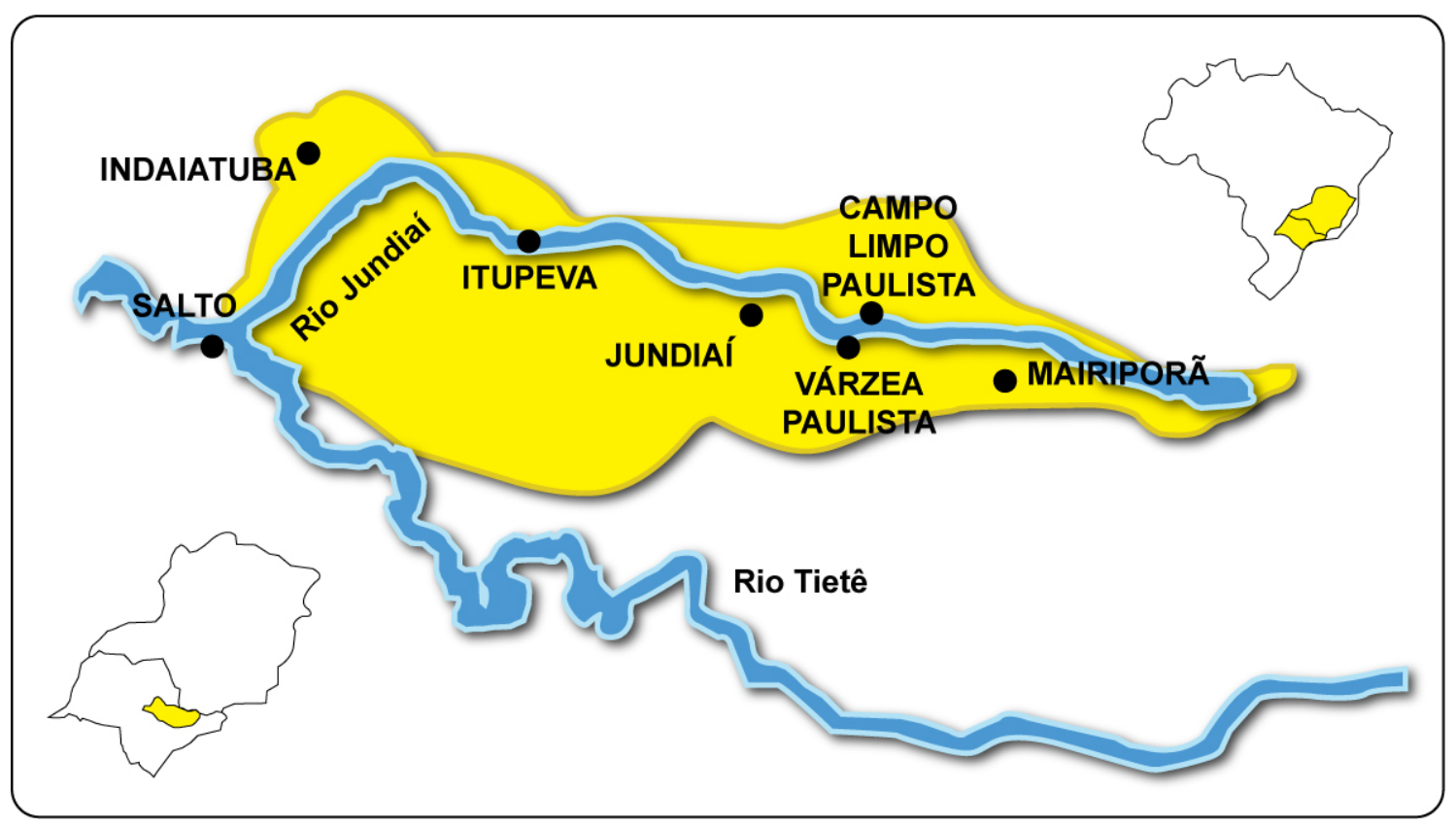

Figura 2 - Mapa da bacia do rio Jundiaí (nascente até foz). Fonte: CETESB, 2009.

A bacia do Rio Jundiaí tem aproximadamente $1.200 \mathrm{Km}^{2}$, clima úmido, temperatura média anual entre $18{ }^{\circ} \mathrm{C}$ e $20^{\circ} \mathrm{C}$, com mínimas de $6^{\circ} \mathrm{C}$ e máximas de $36^{\circ} \mathrm{C}$, e precipitação pluviométrica anual de $1.300 \mathrm{~mm}$ por ano. A cobertura vegetal é na sua maior parte de reflorestamento, com predominância de eucaliptos e pinnus, tendo porém parte de reserva florestal com vegetação nativa na Serra do Japi e Serra dos Cristais, protegida pela Legislação Municipal no Município de Jundiaí e pela Legislação Estadual no seu todo, vegetação esta que representa uma das últimas reservas da Mata Atlântica no interior do Estado de São Paulo (DAE, 2009).

Está é a menor bacia Hidrográfica do estado de São Paulo e também uma das mais industrializadas, contando com indústrias alimentícias, químicas e metalúrgicas que geram a maior parte dos recursos econômicos da região. A instalação de indústrias na região, intensificada a partir da década de 30 acelerou o desenvolvimento urbano das cidades da bacia, impondo um ritmo que não pode ser acompanhado pelo Poder Público, na execução das obras de infraestrutura. Nas cidades de Jundiaí, Itupeva e Indaiatuba, há uma razoável atividade agrícola, com cultivo de lavouras de subsistência frutífera em especial uva, morango, pêssego e café. Destacam-se ainda as atividades de extração de argila e caolim nas cidades de Jundiaí, Indaiatuba e Salto. 
A utilização da água superficial da bacia do Rio Jundiaí é feita principalmente para o abastecimento urbano (58\%). O uso rural representa $24 \%$ e o uso industrial, 17\%. A demanda total de água superficial, considerando todos os tipos de uso, é avaliada em 3,86 m³/s (São Paulo, Conselho Estadual de Recursos Hídricos, 2004).

Em conseqüência, os cursos d'água da Bacia passaram a receber volumes cada vez maiores de resíduos líquidos, industriais e domésticos, sem nenhum tratamento. Tal fato contribuiu para a degradação do Rio Jundiaí e tornou-o um canal de esgotos a céu aberto, principalmente nos períodos de estiagem, quando a vazão se reduz à cerca de 800 litros por segundo.

Desde 2004, os relatórios da CETESB vêm apresentando pioras na qualidade das águas do Rio Jundiaí, o que decorre, principalmente, dos lançamentos de esgotos domésticos sem tratamento das cidades a sua montante.

O índice de qualidade das águas teve média Boa no ponto de captação de Campo Limpo Paulista, porém, para o ponto de Itupeva, o índice foi considerado péssimo. O índice de proteção da vida aquática obteve médias de regular e péssimo, respectivamente. Em seu trecho de Classe 4, foram obtidos, inclusive, resultados positivos para mutagenicidade (CETESB 2004 e 2007). Os pontos de monitoramento realizados pela CETESB bem como sua classificação estão representados na figura 3.

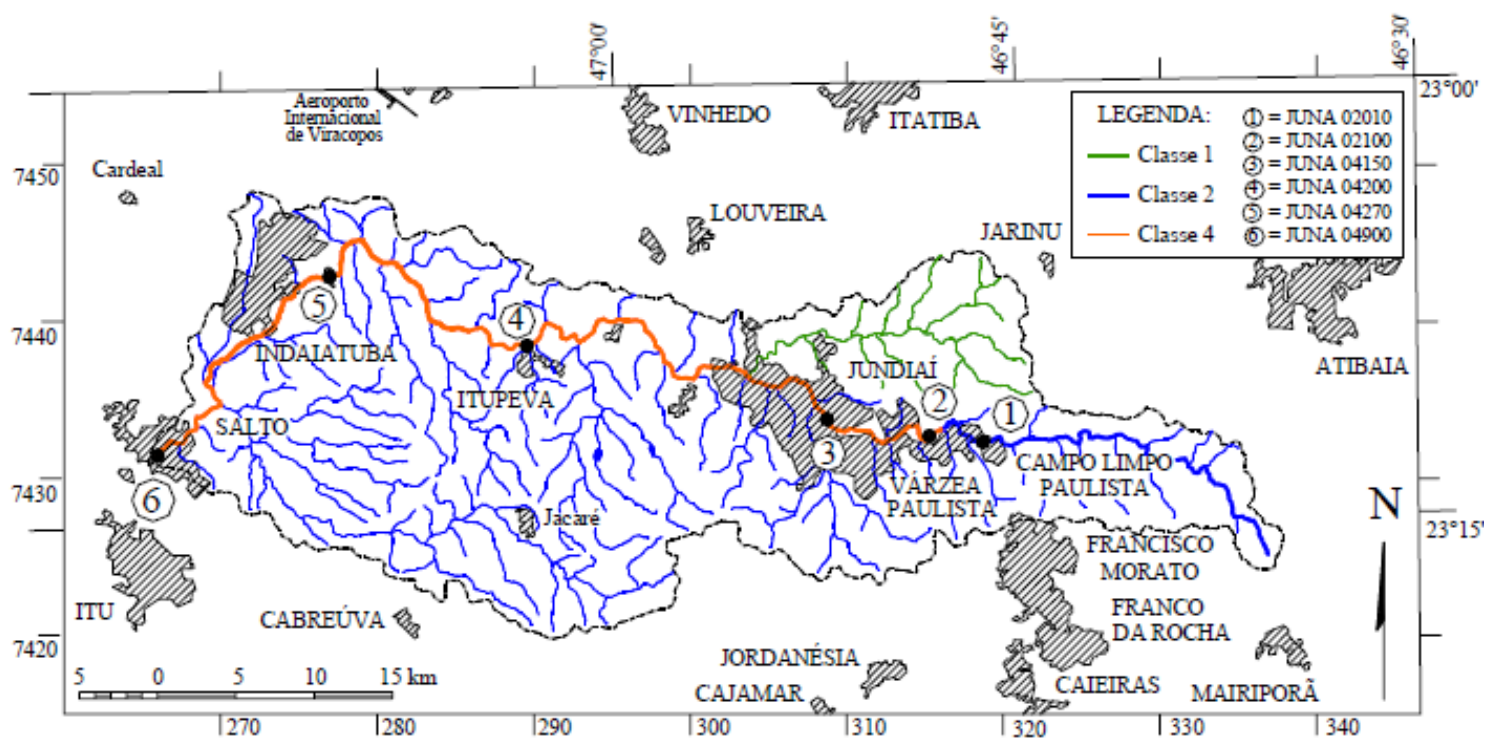

Figura 3 - Enquadramento dos rios da bacia do Rio Jundiaí e localização dos pontos de monitoramento da CETESB. 
A classificação da qualidade das águas nos pontos destacados na figura 3 é feita de acordo com os padrões da resolução $n^{\circ} 357$ do Conselho Nacional de Meio Ambiente (CONAMA), na qual a classe 4 indica a pior qualidade e a 1 , a melhor.

Atualmente, a despoluição do Rio Jundiaí e a conseqüente recuperação da qualidade das águas de sua bacia consistem, basicamente, na construção de um sistema de coleta e transporte dos esgotos domésticos e industriais gerados nas cidades e conectados aos sistemas de tratamento. Nas cidades de Jundiaí e Indaiatuba, já existem estações de tratamento de esgotos (ETEs) em funcionamento e, a da cidade de Salto, deve entrar em operação em breve. Já nas cidades de Itupeva, Campo Limpo Paulista e Várzea Paulista ainda não foram construídas ETEs. (Gramolelli et. al., 2006). 


\section{REVISÃO BIBLIOGRÁFICA}

\subsection{Tratamento de Esgotos}

No tempo em que os homens eram nômades, poucos humanos viviam sobre a terra, porém com o passar dos anos, essa população aumentou e o homem passou a utilizar o ambiente para obter benefícios. Aprendeu a plantar, a domar e criar animais, iniciando a manufatura, a urbanização e a industrialização. A urbanização altera o sistema de abastecimento e destinação de resíduos. Grandes obras de abastecimento de água e canais para receber efluentes foram construídas na antiga Roma (Rocha et.al., 2009).

No Brasil, os primeiros projetos de saneamento datam do início da década de 50, quando o Serviço Especial de Saúde Pública - SESP (vinculado ao ministério da saúde) começou a assinar convênios com os municípios para financiamento, construção e operação de Sistemas de Abastecimento de Água (SAA) e Sistemas de Esgotamento Sanitário (SES), em municípios e localidades urbanas e rurais (Brasil, 2004).

Por outro lado, a poluição generalizada de rios mais ou menos caudalosos só se iniciou com a introdução de sistemas de efluentes domésticos nas cidades. A partir do século XVIII, a situação agravou-se devido ao aumento da população e do início da era industrial. Dessa forma, surgiram mais sistemas de efluentes sanitários e industriais, cujo destino final eram os rios, que começaram a sofrer os efeitos da poluição (morte de peixes, mau cheiro e transmissão de doenças). Como o foco da revolução industrial ocorreu na Inglaterra, esse foi o país que mais sofreu com o problema de poluição dos rios e, consequentemente, onde surgiram as primeiras tentativas de medir e caracterizar a poluição, os primeiros regulamentos de proteção sanitária e os primeiros processos de tratamento de águas residuais (Branco, 1986).

Atualmente, muitas cidades no mundo possuem tratamento de efluentes, porém esse número precisa crescer, pois uma grande quantidade de rios continua recebendo efluentes sem tratamento algum, sendo que a cada dia 0 homem busca mais água. Rebouças (1994) fez um levantamento sobre condições de demanda total de água dos países da Comunidade Econômica 
Européia, demonstrando que $30 \%$ já apresentavam condições críticas de abastecimento devido à deterioração da qualidade das águas.

Os esgotos são compostos por diversas fontes de contaminação: domésticas, industriais, hospitalares, águas de infiltração, entre outras. Os sistemas de esgoto são divididos em públicos e individuais (Carvalho, 2008). Cada indivíduo gera em média 1,8 litros de excretas por dia, sendo 350 gramas de sólidos secos (Dacach, 1990).

Segundo o IBGE (2007), o Brasil atende $51,3 \%$ de sua população por redes de esgoto, enquanto que o estado de São Paulo atende 87,3\% (SEADE, 2009).

A cidade de Jundiaí conta com a Estação de Tratamento de Esgotos Novo Horizonte, inaugurada em 23 de setembro de 1998, que faz parte do projeto de recuperação do Rio Jundiaí, e construída pela iniciativa privada a partir de uma concessão de 20 anos. A empresa construiu a estação de tratamento de esgoto de Jundiaí, onde passou a tratar os esgotos residenciais, comerciais e industriais do município de Jundiaí. Hoje, a estação recebe cerca de 1.562,5 toneladas DBO/ mês (DAE, 2009).

Construída pela Companhia de Saneamento de Jundiaí (CSJ), a ETE tem quase 500 mil metros quadrados, sendo a maior do interior do estado, possui 2 lagoas de aeração e 4 de decantação, que resulta em duas saídas de efluentes tratados que são despejados no rio Jundiaí em seu trecho que está enquadrado na classe 4.

Os efluentes domésticos provêm de águas utilizadas para fins higiênicos e sanitários em residências e locais públicos, constituídos por $99 \%$ de água e $1 \%$ de material sólido suspenso, coloidal ou dissolvido. Apenas $30 \%$ do total de sólidos correspondem à fração inorgânica, composta por minerais, sais e metais; a fração orgânica (70\%) é composta de proteínas, gorduras e carboidratos (Borrely, 1995). Por outro lado quando grandes volumes de chuva atingem um determinado local as águas lavam ruas levando importante quantidade de resíduos e mesmo lixo em direção aos rios. Outro aspecto relacionado às chuvas fortes é a possibilidade de sobrecarregar volumes de afluentes nas ETEs de modo que boa parte passe para os rios sem o devido tratamento.

Os efluentes industriais são compostos por um grande número de diferentes moléculas orgânicas sintéticas, substâncias tóxicas como os fenóis, o 
benzeno, pesticidas, detergentes e surfactantes. Esses compostos tóxicos reduzem as fontes de oxigênio da água dificultando o processo de tratamento além de afetar quase todas as formas de vida aquática (Duarte, 1999).

O tratamento de esgotos pode ser dividido em sistemas individuais e sistemas públicos. Os sistemas individuais são rústicos podendo ser compostos por: Fossa séptica, que consiste em caixa de gordura, caixa de inspeção, caixa séptica, sumidouro; Fossa seca: disposição direta e exclusiva de urina e fezes humanas sem uso de água para transportá-las; Fossa Negra: escavação profunda cujo fundo pode contatar ou se aproximar de um lençol freático. Recebe dejetos humanos e outras águas residuais.

Os sistemas públicos de esgotos são operados por uma instituição chamada de "órgão operador" que no caso da cidade de Jundiaí é o DAE Água e Esgoto S/A. Esse sistema é composto por:

- Canalização: onde todo o esgoto é coletado das casas, prédios, indústrias e levado até um emissário final que destina todo esse efluente para a Estação de Tratamento de Esgoto (ETE).

- Estações elevatórias: utilizadas para o bombeamento de esgoto no caso de locais abaixo do nível da ETE.

- Estações de Tratamento de Esgoto: reduzem o conteúdo orgânico, inorgânico e microbiano do esgoto antes de lançá-lo no rio, diminuindo os riscos que ele apresenta para a saúde pública.

No país existem sistemas compostos de tratamento de esgotos sendo que, na maioria deles, o principal processo é o biológico. A biodegradação pode ser obtida por uso de lagoas de estabilização, lodos ativados, filtros biológicos, entre outros.

Lagoas aeradas: providas de equipamentos de aeração cuja principal finalidade é introduzir oxigênio à massa líquida. $O$ esgoto bruto é lançado diretamente na lagoa depois de passar por um tratamento preliminar (gradeamento e desarenação), e ocorre degradação por meio da ação das bactérias que degradam a matéria orgânica. Tem profundidade de 3,0 a 5,0m (Mendonça, 1990). No Brasil é comum sistemas de tratamento que envolvem lagoas anaeróbias e facultativas (Branco, 1986; Borrely, 1995). 
Filtro Biológico: utilizam um suporte extremamente permeável, em geral pedra ou material plástico, em que os microrganismos se fixam e através do qual o esgoto percola. Os efluentes são despejados por meio de aspersores, o que possibilita maior aeração e distribuição do esgoto. A degradação é feita a partir das bactérias facultativas predominantes nos filtros biológicos e também bactérias aeróbias e anaeróbias, fungos, algas e protozoários que integram a comunidade biológica (Philippi, 2005).

Lodo Ativado: consiste num sistema no qual uma massa biológica cresce, forma flocos e é continuamente recirculada e colocada em contato com a matéria orgânica sempre com a presença de oxigênio (aeróbio). O processo é estritamente biológico e aeróbio, sendo que o esgoto bruto e o lodo ativado são misturados intimamente, agitados e aerados em unidades conhecidas como tanques de aeração. Após este procedimento, o lodo é enviado para o decantador secundário, onde a parte sólida é separada do esgoto tratado. O lodo sedimentado retorna ao tanque de aeração ou é retirado para tratamento específico. (SABESP, 2009).

Os projetos de estações de tratamento optam por alguma combinação de processos sejam lagoas anaeróbias com facultativas, quando existem espaço e insolação disponíveis; lodos ativados com tanques de decantação prévios ao tratamento biológico, com etapas específicas para tratamento dos sólidos (lodo residual). Novas combinações surgem para as indústrias que se utilizam de processos avançados de oxidação e/ou osmose reversa, membranas de filtração, etc.

No Brasil, os esgotos são tratados até os níveis secundários para reduzir substancialmente a matéria orgânica, enquanto países desenvolvidos contam com o tratamento terciário. $\mathrm{O}$ tratamento terciário beneficia o ambiente principalmente pela remoção de nitrogênio e fósforo, que acabam atingindo os mananciais em menores proporções quando o efluente é tratado devidamente (Borrely, 2001).

\subsection{Ensaios de Toxicidade}

O termo Ecotoxicologia foi criado pelo pesquisador francês René Truhaut em 1969, englobando duas ciências, a Ecologia e a Toxicologia. A Ecologia estuda a diversidade e representatividade dos organismos e seu 
significado nos ecossistemas, e a Toxicologia estuda os efeitos adversos dos poluentes sobre o organismo, sendo o agente tóxico a substância capaz de causar danos ao sistema biológico. Portanto, podemos definir a Ecotoxicologia como a ciência que estuda e compreende os efeitos deletérios promovidos pelas substâncias químicas, principalmente as de origem antrópica, sobre as populações ou comunidades de organismos presentes nos ecossistemas. Geralmente são utilizados testes de exposição relativamente curta para avaliação dos efeitos agudos e testes de longa duração para avaliação dos efeitos crônicos (Azevedo \& Chasin).

Os primeiros testes de toxicidade foram realizados entre 1863 e 1917, porém só na década de 1930 foram implementados alguns testes de toxicidade aguda utilizando organismos aquáticos para avaliar a relação causa/efeito de substâncias químicas e despejos líquidos, além de estudos realizados na década de 1940 que recomendavam o uso de testes com peixes (Rand, 1995).

No Brasil, os estudos na área de ecotoxicologia iniciaram em 1971, a partir de um trabalho pioneiro realizado por Rocha et. al. no qual a tilápia foi empregada para avaliar o efluente de uma indústria na região do Rio Atibaia (SP) (FESB - CETESB, 1971).

Em 1975, a Companhia de Tecnologia de Saneamento Ambiental do Estado de São Paulo (CETESB), a convite da Associação Brasileira de Normas Técnicas (ABNT), participou de um programa internacional de padronização de testes de toxicidade aguda com peixes. (Zagatto \& Bertoletti - 2006).

Os ensaios de toxicidade podem ser realizados na forma estática, semi-estática, em fluxo contínuo ou em campo. Na forma estática não há renovação da solução-teste durante o ensaio. A forma semi-estática é caracterizada pela renovação periódica da solução-teste. Este sistema é utilizado quando a substância não é muito estável (Nipper, 1998; Borrely, 2001).

A renovação de soluções durante ensaios de duração mais longa, ou ainda os ensaios com fluxo contínuo, foram desenvolvidos para assegurar a eliminação dos excretas dos organismos durante o período de ensaio, a manutenção da concentração da substância tóxica e oxigênio dissolvido, além da eliminação de alimento e resíduos (Pereira el al.,1987). 
Os ensaios de toxicidade podem ser classificados segundo os efeitos que os organismos venham apresentar durante o tempo de exposição dos ensaios (Nipper, 1998; Borrely, 2001) em:

- Toxicidade Aguda - ensaios de curta duração que abrangem apenas parte do ciclo de vida do organismo-teste; normalmente avaliam a mortalidade ou a imobilidade dos organismos, influência em reações bioquímicas, metabolismo, entre outros.

- Toxicidade Crônica - ensaios com exposição prolongada, que podem abranger todo o ciclo de vida dos organismos-teste; avaliam parâmetros subletais como reprodução, deformidades e o crescimento.

- Toxicidade Crônica de curta duração - periodos de exposição mais curtos em relação aos ensaios crônicos tradicionais, que abrangem partes sensíveis do ciclo de vida dos organismos-teste, avaliando parâmentros subletais.

Os fenômenos gerais de ação de um composto tóxico a um determinado organismo-teste podem ser divididos em 3 etapas/processos toxicológicos: a fase de exposição, a fase toxicocinética e a fase toxicodinâmica. A fase de exposição avalia o tempo em que o organismo é exposto a um composto tóxico. A fase toxicocinética compreende a absorção, distribuição, metabolismo e eliminação do composto tóxico pelo organismo. A fase toxicodinâmica envolve o tempo de resposta biológica do organismo em função da ação tóxica, e sua interação com receptores do local (Rand,1995). A figura 4 ilustra os níveis de efeito biológico dos contaminantes e sua relevância ecológica. 


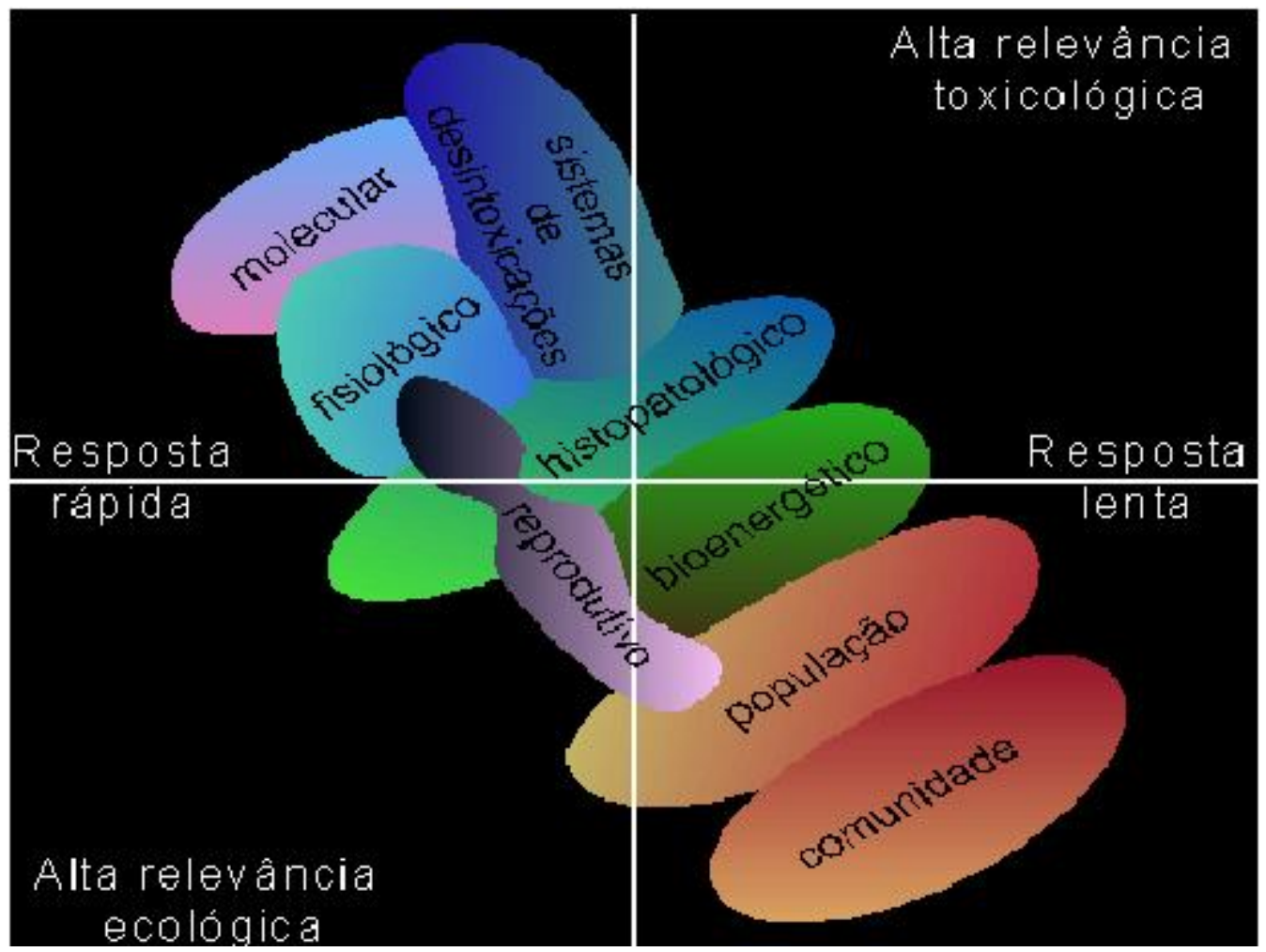

Fonte: www.esd.ornl.bioassays (março 2009)

Figura 4 - Níveis de efeito biológico dos contaminantes e sua relevância ecológica.

Os resultados dos ensaios de toxicidade são normalmente expresssos como CL (concentração letal), CE (concentração efetiva)), Cl (concentração de inibição), CENO (concentração de efeito não observado) e CEO (concentraçao de efeito observado). A CL e a CE representam, respectivamente, a Concentração Letal e a Concentração Efetiva de uma amostra a uma determinada porcentagem de organismos expostos. A CL50 e a CE(I)50, isto é, a Concentração Letal e a Concentração Efetiva a $50 \%$ dos organismos expostos, são as mais utilizadas em uma avaliação de efeito agudo. A Concentração Inibitória, $\mathrm{Cl}$, é utilizada para ensaios de efeito agudo ou crônico (Romanelli, 2004). A CENO e CEO representam a Concentração de Efeito Não Observado e a Concentraçõ de Efeito Observado, respectivamente (Nipper, 1998). Esses dois parâmetros juntos permitem a determinação de uma faixa de sensibilidade e não de um valor absoluto de concentração do agente tóxico, e são utilizados em ensaios de toxicidade crônica. 
Vários estudos vêm sendo desenvolvidos com base na ecotoxicologia. Os ensaios de toxicidade aguda foram os primeiros a serem empregados devido ao baixo custo e curta duração (Birge et. al., 1985).

A presença de agentes tóxicos em estações de tratamento de efluentes (ETEs) pode causar impacto na atividade biológica e, consequentemente, a redução da eficiência do tratamento. Alguns agentes tóxicos passam pelo sistema de tratamento sem sofrer nenhuma alteração, acabam chegando ao corpo receptor, comprometendo a biota do mesmo. A concentração elevada de substâncias no lodo, dificulta a biodegradação do esgoto e também restringe a utilização do lodo como fertilizante.

Entre março de 1984 e julho de 1985, a CETESB realizou um estudo na região de Cubatão para avaliar a qualidade das águas e sedimentos dos rios que recebiam efluentes líquidos industriais, utilizando análises físico-químicas e ecotoxicológicas. Foi também analisada a comunidade bentônica do rio Cubatão e seus afluentes. Foi verificado que as águas do rio Cubatão causavam efeito tóxico agudo a Daphnia similis, principalmente em amostras localizadas a jusante dos lançamentos industriais.

Zagatto et. al. (1992) avaliaram a toxicidade dos efluentes da ETE Suzano com Daphnia similis com o intuito de calcular a redução de toxicidade da ETE e seu impacto no rio Tietê. Trabalho semelhante foi realizado por Hamada (2008).

Buscando alternativas para o tratamento de efluentes especiais, Borrely (2001) aplicou a radiação ionizante no tratamento de efluentes industriais e domésticos da ETE Suzano, São Paulo. A eficiência da radiação na degradação de contaminantes orgânicos foi avaliada com ensaios de toxicidade aguda utilizando Daphnia similis, Vibrio fischeri e Poecilia reticulata. Foi observada a redução gradual da toxicidade, entre $75 \%$ e $95 \%$, com aumento das doses aplicadas, entre 5 kGy e 50 kGy, utilizando-se um acelerador de elétrons.

Testes de toxicidade com Daphnia similis foram realizados no CESET/ UNICAMP para avaliar a toxicidade aguda dos detergentes domésticos e dos detergentes utilizados em laboratórios em sua forma pura e diluída (1:100). Foram obtidos resultados de $\mathrm{CE}_{50}$ de $0,17 \mu \mathrm{L} / \mathrm{L}$ para o detergente de uso doméstico e $0,03 \mu \mathrm{L} / \mathrm{L}$ e $1,72 \mu \mathrm{L} / \mathrm{L}$ para o detergente de laboratório em sua forma pura e diluída respectivamente, podendo-se concluir que efluentes contendo detergentes 
tem que passar por processo de tratamento, devido ao seu potencial de causar impacto para os organismos aquáticos (Leandro-Alves et. al., 2008).

Em estudo realizado no estado do Espírito Santo, a bactéria luminescente Vibrio fischeri foi utilizada para avaliar impactos causados por derramamentos de óleo diesel e óleo combustível. Estudando sedimento, verificou-se que mesmo após 7 meses decorridos do derramamento de óleo diesel e 2 anos após o acidente com óleo combustível, os corpos d'água ainda apresentavam toxicidade para $V$. fischeri (D'lsep et. al, 2008).

Antes mesmo do início de operação da ETE Suzano, GherardiGoldstein et. al. (1983) realizaram um estudo ecotoxicológico em 20 indústrias da região de Suzano e Mogi das Cruzes (cidades atendidas pela ETE Suzano). Foi utilizando o microcrustáceo Daphnia simillis e apenas três delas não apresentaram toxicidade. Os contaminantes residuais de origem industrial foram analisados isoladamente e os que apresentaram toxicidade para 0 microcrustáceo, foram os mesmos que são conhecidamente tóxicos a tratamentos biológicos de efluentes.

Em 2000 efluentes de dezoito estações de tratamento de esgotos de Sidney, Austrália foram avaliadas em relação à toxicidade aguda e crônica. A alga Selenastrum capricornutum e o microcrustáceo Ceriodaphnia dubia foram utilizados como organismos-teste. Em quinze das dezoito estações foi encontrada toxicidade aguda ou crônica para C. dubia enquanto que para as algas somente duas estações apresentaram toxicidade (Bailey et. al., 2000).

Slaterry (1984) demonstrou que quando a toxicidade do afluente de um sistema de tratamento de esgotos estiver menor que 10\% (CE50<10\%) os organismos presentes na ETE se tornam inativos, prejudicando todo o sistema. Com este valor pode-se estimar as taxas de liberação de um afluente tóxico em um sistema de tratamentos se for determinada uma relação similar entre a inibição da bioluminescência pelo sistema Microtox e a atividade microbiana dos organismos presentes no lodo ativado.

Em estudo realizado com 35 compostos gerados pelo processo Kraft da produção de papel e celulose. Peixes foram expostos isoladamente a cada um dos contaminantes por 96 horas. Os compostos foram considerados muito tóxicos pois apresentaram CL50-96h em sua maioria em concentrações inferiores a 10\% da amostra (McKean, 1980; Gherardi-Goldstein, 1988; Borrely, 2001). 
Villegas-Navarro et. al. (1999) determinaram a toxicidade de efluentes de cinco indústrias têxteis em Puebla, Mexico. Foram utilizados ensaios de toxicidade aguda com Daphnia magna na entrada e na saída da estação de tratamento biológico, determinando sua eficiência. Foi obtida eficiênia entre $33 \%$ e $89 \%$, apesar dos efluentes ainda apresentarem toxicidade após o tratamento.

Três estações de tratamento de efluentes da Tunísia foram avaliadas em relação ao recebimento de efluentes industriais. As estações de Sfax e Mahres recebem esse tipo de efluente, enquanto que a estação de Ksour-Essaf recebe somente efluentes domésticos. Por meio de ensaios com Vibrio fischeri foi confirmada que a presença de efluentes industriais é nociva devido a toxicidade residual encontrada nas ETEs de Sfax e Mahres (Ellouse et. al., 2009).

Um projeto europeu desenvolvido a Bacia do Rio Trancão em Portugal integrou testes ecotoxicológicos e físico-químicos em efluentes e duas redes de esgoto municipais e suas respectivas estações de tratamento de esgotos. Os ensaios físico-químicos realizados foram, $\mathrm{pH}, \mathrm{OD}, \mathrm{DBO}$, sólidos totais, determinação de óleos e hidrocarbonetos; enquanto que os ensaios de toxicidade utilizaram Vibrio fischeri, Pseudokirchneriella subcapitata, Thamnocephalus platyurus, Daphnia magna, Lemna minor. Ficou demonstrado que a Vibrio fischeri Foi o organismo de maior sensibilidade (Mendonça, 2009).

A Resolução $n^{\circ} 357$, CONAMA, foi editada em razão da necessidade de criar instrumentos para avaliar a evolução da qualidade das águas e de reformular a classificação até então existente. Além disso, tem como objetivo criar meios legais para melhor distribuir o uso das águas, especificar as condições e padrões de qualidade de águas marinhas, estuarinas e continentais, bem como regulamentar o lançamento de efluentes em corpos d'água.

Assim, no que concerne especificamente à ecotoxicologia, a Resolução CONAMA estabelece a definição de ensaios ecotoxicológicos que deve ser considerada para fins de interpretação da própria norma, conforme artigo $2^{\circ}, \mathrm{XXI}$. Ademais, estabelece ensaios ecotoxicológicos como ferramentas legais para indicação da qualidade da água, conforme se verifica do disposto no artigo $8^{\circ}, \S$ $4^{\circ}$. O CAPÍTULO IV versa sobre as condições e padrões de lançamento de efluentes em corpos de água deixando claro que os efluentes devem passar por tratamentos antes de serem lançados, de forma a evitar que poluam as fontes naturais de água. 
$\mathrm{O}$ art. $34, \S 2^{\circ}$, estabelece critérios de toxicidade que devem ser baseados em resultados de ensaios ecotoxicológicos padronizados, utilizando organismos aquáticos, e realizados no efluente, destacando, mais uma vez, a importância da ecotoxicologia para a preservação das águas. Desse modo, os estudos ecotoxicológicos tornam-se ferramenta imprescindível e legal para a preservação da qualidade da água e recursos hídricos, cada vez mais escassos.

\subsection{Qualidade Ambiental e Saúde}

A exposição humana a poluentes existentes no ar, na água, no solo e nos alimentos é um contribuinte, direto e indireto, para o aumento da morbidade e da mortalidade, comprovando, assim, a estreita relação entre qualidade ambiental e saúde. Os agentes biológicos, químicos e físicos são responsáveis tanto por efeitos subclínicos até a doença e morte. Essa exposição pode ser percebida quando ocorre tanto na forma aguda, em episódios com altos níveis de concentração, como ao longo do tempo, com baixos níveis de exposição (Phillippi $\mathrm{Jr}, 2005)$.

Segundo o relatório "Situação Global de Suprimento de Água e Saneamento" de 2000, elaborado pela Organização Mundial da Saúde, 2,4 bilhões de pessoas em todo o mundo não possuem condições aceitáveis de saneamento e outras 1,1 bilhões não têm acesso a abastecimento adequado de água. Esta situação persiste em países em desenvolvimento: aproximadamente 1,3 bilhões de pessoas não dispõe de fontes de água adequadas e metade deste total não tem acesso a saneamento. A água contaminada pode transmitir doenças infecciosas, parasitas de pele ou intestinais ou por vetores com ciclo de vida na água (OPAS, 2001).

No município de Jundiaí há cerca de $3 \%$ de casos de morte causados por infecções e parasitas; $34 \%$ entre ocorrências de doenças pulmonares e neoplasias, conforme apresentado na figura 5. Em 2006 os gastos com saúde atingiram $R \$ 132.733 .383,59$ (DATASUS, 2006).

Algumas doenças como neoplasias, doenças do aparelho respiratório, e circulatório podem estar associadas a fatores ambientais como poluição das águas, do ar, do solo e sonora (Saneamento Ambiental, 2009; Nature News, 2009). 


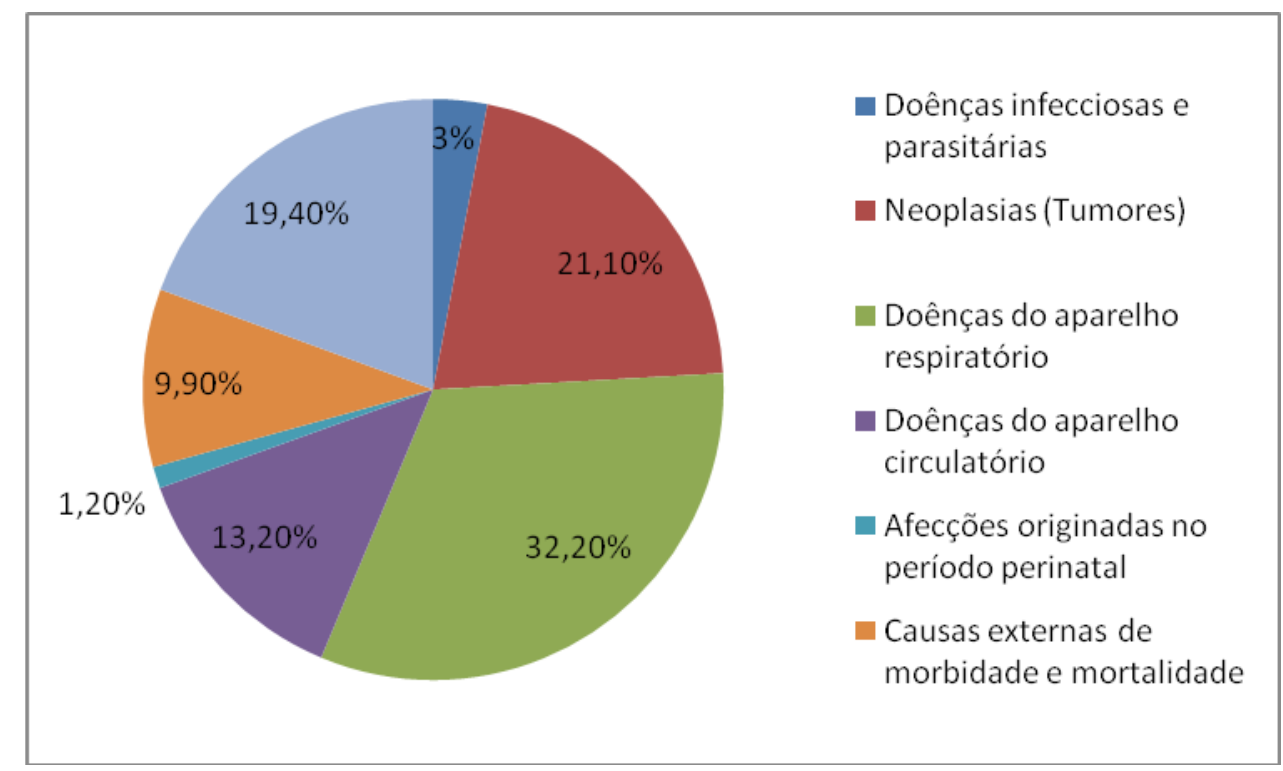

Fonte: DATASUS - 2006

Figura 5 - Relação causa-morte em Jundiaí referente a 2005

Segundo dados da secretaria de saúde, a taxa de mortalidade infantil do município de Jundiaí entre os anos de 2000 e 2004 é decrescente, podendo estar relacionada com as melhorias no saneamento, bem como melhor atendimento em saúde (Secretaria de Saúde, 2005).

De acordo com a Organização Mundial de Saúde (OMS), a cada Real gasto com saneamento, o Estado economiza cinco em saúde pública. No Brasil, cerca de 233 mil pessoas morrem todo ano por exposição a fatores de risco ambiental, como poluição, água não tratada.

Um exemplo negativo da relação entre saúde ambiental e saúde pública foi a contaminação de moradores da Vila Carioca na cidade de São Paulo por substâncias tóxicas produzidas pela Shell Brasil S/A. Na Vila Carioca, o índice de mortalidade é maior que em outros bairros do distrito do Ipiranga. $\mathrm{O}$ solo e $\mathrm{O}$ lençol freático estão contaminados pelos pesticidas organoclorados Aldrin, Dieldrin, Dicloro-Difenil-Tricloroetano (DDT) e DDE (metabólito do DDT); substâncias cancerígenas também foram encontradas no organismo de moradores do bairro. Entre 1994 e 2003, foram registradas 8.112 mortes em toda a região estudada, das quais 687 ocorreram somente na região da Vila Carioca e 7.425 no restante do distrito do Ipiranga (Saneamento Ambiental, 2009). 
Outro exemplo foi um relatório realizado nos Estados Unidos: traços de uma série de medicamentos, produtos de cuidados pessoais, pesticidas e outros contaminantes foram encontrados na água potável servida a milhões de norteamericanos. Nenhum dos compostos surgiu em níveis tidos como imediatamente prejudiciais à saúde humana, porém os pesquisadores ficaram surpresos ao encontrar traços generalizados de um pesticida (Atrazine) usado no cultivo de milho, cuja presença, em níveis mais elevados, já foi vinculada ao câncer e outros problemas de saúde.

O Atrazine poderia estar chegando à água via alimentação, já que muitos refrigerantes, por exemplo, contém xarope de milho, o que ajuda o pesticida a se difundir pelo sistema de tratamento de água. Segundo Jorg Drewes, parece existir maior contribuição vinda dos produtos químicos industriais do que dos produtos farmacêuticos. (Nature News, 2009) 


\section{OBJETIVOS}

Este estudo teve como objetivo avaliar a toxicidade aguda e crônica em afluentes e efluentes da ETE Novo Horizonte, e em águas do rio Jundiaí. As principais etapas desenvolvidas foram:

- Aplicação ensaios de toxicidade aguda e crônica nas águas do rio Jundiaí, com organismos Daphnia similis, Ceriodaphnia dubia e a bactéria luminescente Vibrio fischeri.

- Emprego de ensaios de toxicidade aguda e crônica nos afluentes e efluentes da ETE.

- Caracterizar os parâmetros físicos e químicos nos efluentes antes e após o tratamento biológico da estação.

- Revisar estudos da qualidade das águas do rio Jundiaí a partir de dados que constam no relatório de águas interiores da CETESB. 


\section{MATERIAIS E MÉTODOS}

O trabalho foi desenvolvido utilizando as amostras de efluentes misturados na Estação de Tratamento de Esgotos de Jundiaí, ETE Novo Horizonte e águas do rio Jundiaí. Os ensaios ecotoxicológicos foram realizados com organismos de dois níveis tróficos diferentes, sendo eles dois cládoceros, Daphnia similis e Ceriodaphnia dubia, e a bactéria luminescente Vibrio fischeri.

O critério para a seleção desses organismos aquáticos foi a sensibilidade do organismo a diversos agentes químicos, possibilidade de cultivo e manutenção no Laboratório, ampla distribuição geográfica, o que representa a importância da resposta biológica obtida, a forte utilização dos crustáceos na ecotoxicologia na grande maioria dos países, o que permite a comparação entre os estudos e a proteção do ambiente aquático. Por fim, devem-se buscar espécies com estabilidade genética e que possibilitem a obtenção de lotes uniformes de organismos (Zagatto \& Bertoletti, 2006).

\subsection{ETE Novo Horizonte, Jundiaí, São Paulo}

A Estação tem quase 500 mil metros quadrados, sendo a maior do interior do estado. Possui 2 lagoas de aeração e 4 de decantação, que resulta em duas saídas de efluentes tratados. O tempo de detenção dos afluentes no tratamento é de aproximadamente cinco dias. O sistema de oxigenação das lagoas utiliza ar difuso, evitando contaminação por aerossóis. Apesar da cidade ter cerca de 347 mil habitantes (IBGE, 2007), a estação foi projetada para atender uma carga de demanda bioquímica de oxigênio (DBO) equivalente a de uma população de 1 milhão de habitantes, já que também recebe efluentes industriais. Foi a primeira no Brasil a utilizar ar difuso em lagoas com difusores flutuantes de membrana que não emite aerossóis, reduzindo o prejuízo à população vizinha. Essa ETE recebe uma vazão média diária de $79 \mathrm{mil} \mathrm{m}^{3} /$ dia com uma DBO média de 1400 toneladas, apresentando eficiência de 95\% na remoção de DBO. Há ainda uma área para que ela possa ser ampliada. Mas, já de início, a estação trata $100 \%$ do esgoto coletado na cidade (DAE, 2006).

O esgoto percorre uma distância de $14 \mathrm{~km}$ pelos adutores e Interceptores com diâmetros variados desde $0,30 \mathrm{~m}$ a 2,00m de diâmetro para 
chegar até a ETE. Todo o esgoto do município de Jundiaí, seja ele de origem doméstica ou industrial, passa por cinco etapas de tratamento.

$\mathrm{Na} E T E$, o efluente passa pelo gradeamento, onde existem dois níveis de plataformas com grades de diferentes espaçamentos, que fazem a retenção de sólidos grosseiros que adentram na estação, como plásticos, garrafas, panos, maços de cigarros etc., e outra para a retenção de sólidos menores.

Após passar pelas grades, o efluente é direcionado a um tanque conhecido como Estação Elevatória de Esgoto Bruto. Nesse local, existem bombas submersas com capacidade para bombear $750 \mathrm{l} / \mathrm{s}$ cada e lançar o esgoto para a remoção de areia. Nessa fase, há caixas que estão situadas antes das lagoas de tratamento, também conhecidas como desarenadores, onde ficam retidos a areia, terra e sólidos relativamente finos. Até esta etapa, ocorre o tratamento de nível primário, que visa à redução de material sólido.

Nas lagoas aeradas (etapa mais importante do tratamento), ocorre a biodegradação pela intensa formação de flocos (floculação). Essas lagoas de aeração são responsáveis por boa parte da eficiência da remoção das cargas orgânicas. Nelas, o esgoto recebe muito oxigênio através de sopradores de ar, o que faz com que as bactérias e outros microrganismos que degradam a matéria orgânica se utilizem do oxigênio dissolvido e se mantenham vivos.

Após a formação dos flocos, o lodo já inerte pela ação das bactérias, é conduzido às lagoas de decantação para sedimentação no fundo da lagoa. Assim, somente $o$ efluente líquido é lançado no rio Jundiaí. $O$ lodo residual que permaneçe no fundo das lagoas de decantação é dragado periodicamente, homogeneizado e desidratado, podendo ser utilizado como condicionador de solos.

O tempo de retenção dos esgotos na estação é de cinco dias, aproximadamente. Em época de muita chuva, isso se altera sobremaneira. $\mathrm{O}$ funcionamento da ETE está representado na figura 6. 


\section{ESTAÇÃO DE TRATAMENTO DE ESGOTO DE JUNDIAÍ}

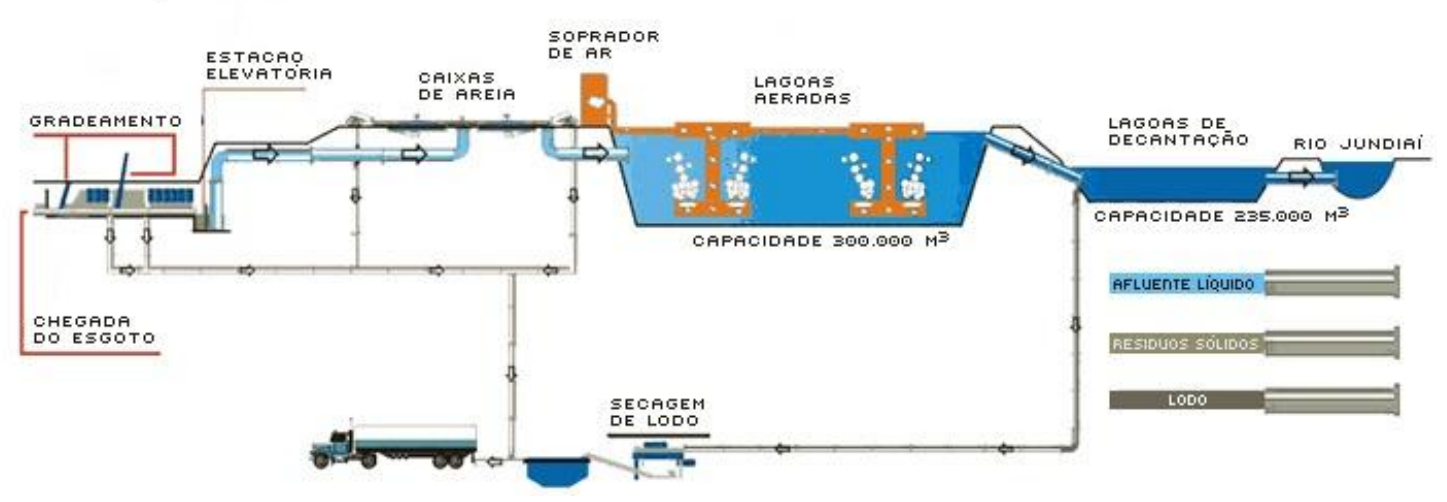

Fonte - CSJ, 2009

Figura 6 - Croqui da Estação de Tratamento de Esgoto de Jundiaí

\subsection{Amostragem}

O plano de amostragem totalizou cinco campanhas e 47 amostras, sendo desenvolvido em duas etapas. Na primeira etapa, foram avaliados os efeitos tóxicos agudos e crônicos nos efluentes finais da estação e em águas do rio onde foram amostrados os pontos P1, P4, P5 e P6. A etapa final foi dedicada aos afluentes, também levando em consideração o efluente final.

$\mathrm{Na}$ tabela 1 foram organizadas as informações sobre a identificação e data de amostragem, e na figura 7 constam fotos dos pontos de coleta P1 e P6.

$\mathrm{Na}$ última amostragem foram coletados os afluentes (P2, P3) e efluentes (P4). Para P2 e P4, foram coletadas amostras compostas com uso de coletor automático (a cada hora), representando efluentes recebidos pela estação ao longo de 24 horas. Estas amostras foram coletadas entre o dia 18 a 23 de Agosto, totalizando seis amostras, mais seis replicatas. As amostras do P3 (Emissário + EVC) foram coletadas (por nós) de hora em hora durante 6 horas (entre 9 horas e 14 horas) nos dias 19, 20 e 22 de Agosto, contendo material do emissário da Cidade e material que chega via caminhão na ETE, diariamente (EVC).

As amostras foram conservadas sob refrigeração desde o momento da coleta. Parte das amostras foi congelada para uso posterior, assim como as frações a serem utilizadas durante a troca nos ensaios de toxicidade crônica. A validade máxima das amostras é de 60 dias em congelamento (ABNT, 2004). 
Tabela 1 - Pontos de coleta, localização e tipo de amostras coletadas.

\begin{tabular}{|c|c|c|c|}
\hline Ponto & Localização & Tipo de amostra & Campanha \\
\hline P1 & Montante ETE & Água do rio (Pontual) & $1,2,3,4$ \\
\hline P2 & Emissário da & Afluente ETE (Composta) & 5 \\
\hline & Cidade & & \\
\hline P3 & Emissário + EVC & $\begin{array}{l}\text { Afluente ETE (Pontual - } \\
\text { Composta) }\end{array}$ & 5 \\
\hline P4 & & Efluente ETE (Pontual - & $1,2,3,4$, \\
\hline $\begin{array}{l}\text { P5 } \\
\text { P6 }\end{array}$ & $\begin{array}{l}\text { Saída } 2 \text { ETE } \\
\text { Jusante ETE }\end{array}$ & $\begin{array}{l}\text { Composta*) } \\
\text { Efluente ETE (Pontual) } \\
\text { Água do rio (Pontual) }\end{array}$ & $\begin{array}{l}5^{*} \\
1,2,3,4 \\
1,2,3,4 \\
\end{array}$ \\
\hline
\end{tabular}

EVC - efluentes trazidos por caminhões. Datas das Campanhas:1a) 29/06/2007; 2a)18/10/2007; $3^{\text {a) }} 25 / 03 / 2008 ; 4^{\text {a) }}$ 10/07/2008; $5^{\text {a) }}$ ) de 18 a $23 / 08 / 2008$

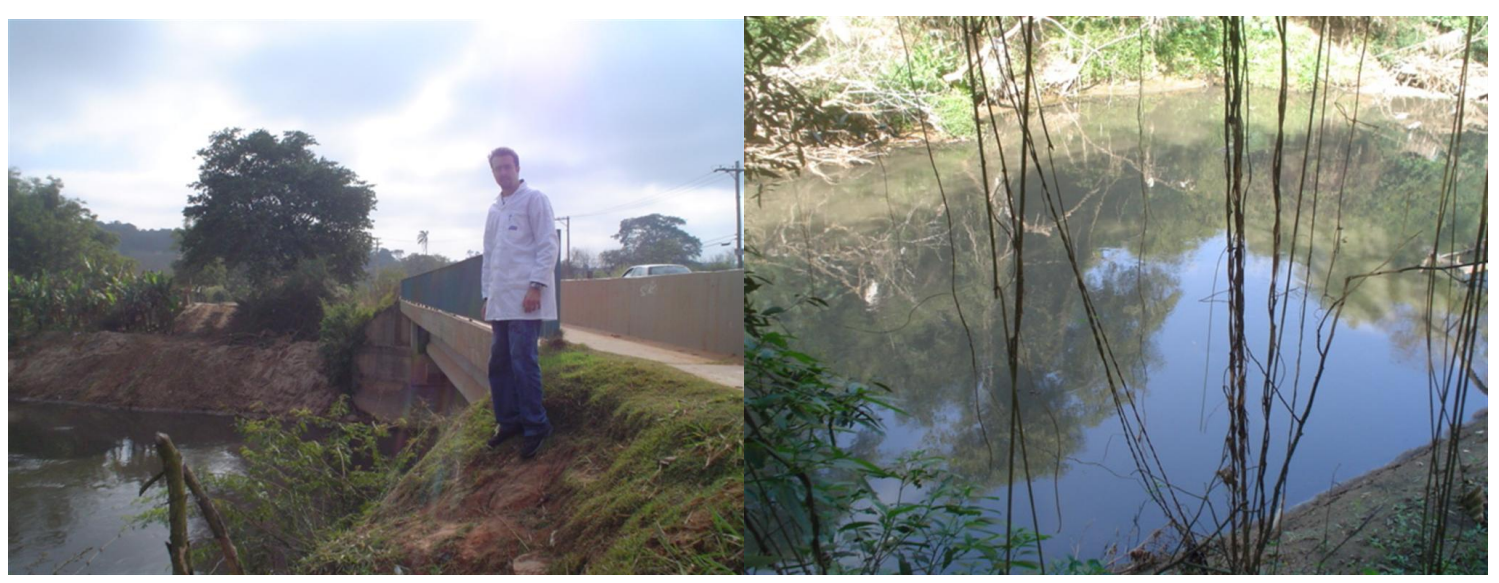

Figura 7 - Pontos de coleta P1 e P6 (montante e jusante da ETE)

\subsection{Ensaios de Toxicidade}

\subsubsection{Microcrustáceos}

Os Microcrustáceos são organismos importantes na cadeia alimentar, pois fazem parte do zooplâncton, representando uma ligação entre os produtores primários e os consumidores secundários, já que se alimentam de algas e servem de alimento para peixes e alguns invertebrados. Vê-se, portanto, que a alteração na população e no comportamento destes organismos pode interferir em outros níveis tróficos do ecossistema aquático (CETESB, 1997). 
Os Organismos Daphnia similis (figura 8) e Ceriodaphnia dubia (figura 9) são microcrustáceos de água doce facilmente encontrado em águas continentais e tem o tamanho de $0,5 \mathrm{~mm}$ a $5,0 \mathrm{~mm}$ e de $0,8 \mathrm{~mm}$ a $0,9 \mathrm{~mm}$, respectivamente. Possuem um corpo coberto por uma carapaça transparente e um olho composto evidente, sensível a variações de intensidade de luz. Possuem longas antenas que são responsáveis pelo impulso natatório para frente. São filtradores e alimentam-se de algas, bactérias e detritos orgânicos (CETESB, 1997).

Em condições ambientais adequadas, esses organismos apresentam reprodução assexuada por partenogênese, em que as fêmeas produzem células diplóides que originam outras fêmeas com o mesmo genótipo, assim apresentando homogeneidade genética, o que permite boa reprodutibilidade dos resultados dos ensaios de toxicidade (Gerardi-Goldstein, 1983).

As fotos dos organismos adultos (figura 8 e 9) foram tiradas com uma câmera Canon SD - 750, acoplada a uma lupa LEICA MZ95.

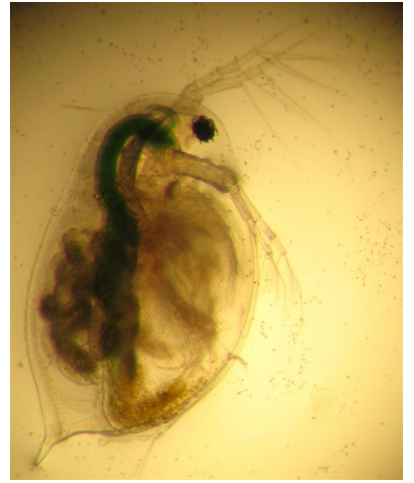

Figura 8 - Daphnia similis adulta

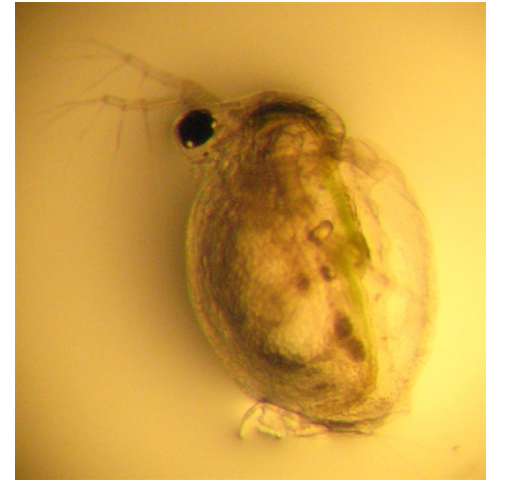

Figura 9 - Ceriodaphnia dubia adulta

\subsubsection{Cultivo de microcrustáceos}

Os microcrustáceos Daphnia similis e Ceriodaphnia dubia utilizados nos ensaios de toxicidade foram cultivados no Laboratório de Ensaios Biológicos e Ambientais do CTR - IPEN, seguindo metodologia padronizada pela ABNT. Assim, foram mantidos em incubadoras de $\mathrm{DBO}$ a $20^{\circ} \mathrm{C} \pm 0,5$ e a $25^{\circ} \mathrm{C} \pm 2 \mathrm{C}^{\circ}$ respectivamente, e fotoperíodo controlado de 14 horas conforme figura 10 . Os cultivos foram mantidos em recipientes separados de acordo com a idade (cristalizadores de vidro com tampa). Para obter os jovens utilizados nos ensaios, 
os neonatos foram retirados todos os dias e no final da semana há troca da água de cultivo.

A água de cultivo utilizada na manutenção e também nas diluições procede do Reservatório Paiva Castro, Mairiporã, São Paulo, sendo coletada mensalmente. A cada lote de água de cultivo foi feito o ajuste de dureza (45 $\mathrm{mg} / \mathrm{L}$ de $\mathrm{CaCO}_{3}$ ), controle de $\mathrm{pH}$. Antes do uso essa água de cultivo e diluição é submetida a aeração e filtração.

Após cada uma das coletas de água de manutenção, foram realizados ensaios de viabilidade com a exposição de pelo menos 10 organismos-teste durante 48 horas, sem alimentação e mantidos na incubadora sob as mesmas condições das culturas. A imobilidade dos organismos não deve exceder $10 \%$ do total de organismos expostos para que a água possa ser utilizada (CETESB, 1997). O alimento utilizado para a manutenção da Daphnia similis e da Ceriodaphnia dubia foi a alga Pseudokirchneriella subcaptata, na concentração de 2,0 $010^{6}$ células por organismo para Daphnia similis e de 1 a $5 \times 10^{5}$ células por organismo para Ceriodaphnia dubia, aproximadamente, complementado com ração de peixe e leveduras $(R L)$.

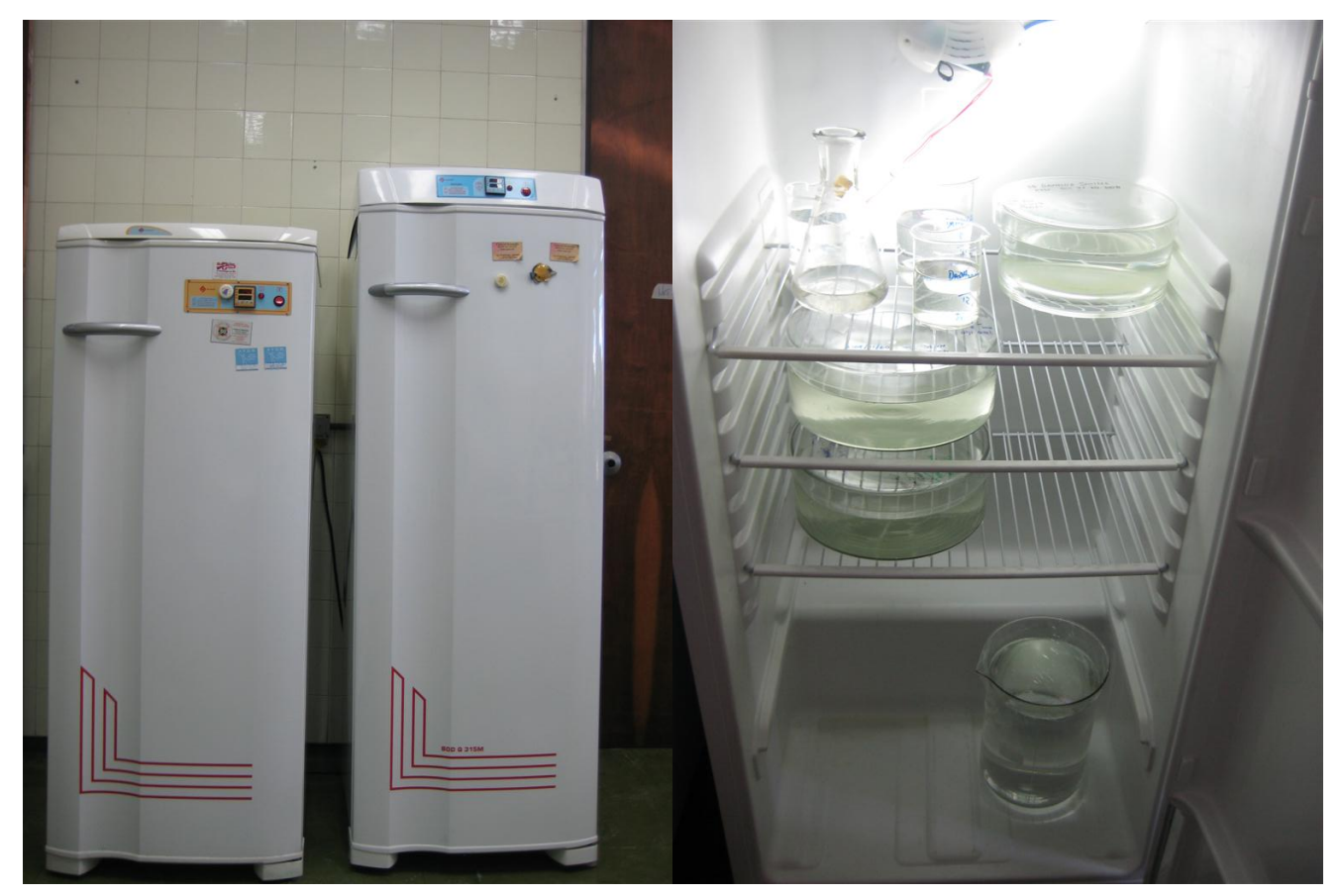

Figura 10 - Incubadoras e cristalizadores utilizados no cultivo de organismos 


\subsection{3 - Ensaios de Toxicidade crônica com Ceriodaphnia dubia}

Foram empregados ensaios com Ceriodaphnia dubia para as amostras de água do rio e do efluente da ETE, com exposição de organismos jovens a $25 \%, 50 \%, 75 \%$ e $100 \%$ de amostra e por período suficiente para quantificar a reprodução durante três crias, totalizando 7 a 8 dias de duração do ensaio.

De acordo com a Norma ABNT- NBR 13373 (2005), as soluções-teste devem ser preparadas no momento da realização do ensaio, utilizando as devidas proporções de amostra.

Antes da transferência dos organismos para as soluções-teste as mesmas foram colocadas na incubadora para adquirir a temperatura do ensaio no momento da transferência dos organismos. Essas soluções-teste consistiram na amostra não diluída e em uma série de diluições.

$\mathrm{O}$ ensaio foi mantido a $25^{\circ} \mathrm{C} \pm 2^{\circ} \mathrm{C}$, por aproximadamente sete dias, em copos de $40 \mathrm{~mL}$ de poliestireno cristal e cobertos conforme figura 3. A alimentação foi realizada diariamente com a alga Pseudokirchneriella subcaptata (antigamente conhecida como Selenastrum capricornutum) na quantidade de aproximadamente $2,0 \times 10^{6}$ células/mL por organismo, acrescido de um complemento alimentar à base de ração fermentada. As soluções-teste foram renovadas três vezes durante o ensaio, de dois em dois dias. O ensaio foi encerrado quando $60 \%$ ou mais das fêmeas adultas sobreviventes no controle (água de cultivo) produziram no mínimo 15 organismos jovens, não ultrapassando o oitavo dia.

Durante o ensaio, foi realizada a leitura, observando-se a sobrevivência e a reprodução dos organismos adultos, quando houve o nascimento, os neonatos foram retirados e registrados em formulários padronizados.

Os ensaios foram realizados com todas as amostras das quatro primeiras campanhas e em duas amostras da saída da ETE (P4 e P5) da quinta campanha.

Mensalmente, a sensibilidade do organismo-teste foi avaliada por meio de carta controle de ensaios com a substância referência cloreto de potássio $(\mathrm{KCl})$ em concentrações de 70, 125, 250 e 300 ppm, cujos resultados constam na tabela 2. 
Tabela 2 - Médias de nascimento para Ceriodaphnia dubia exposta ao $\mathrm{KCl}$

\begin{tabular}{c|ccccc}
\hline Ensaio & Controle & 75 & 125 & 250 & 300 \\
\hline E1 & 22,6 & 22,7 & 12,6 & 6,71 & 7,5 \\
E2 & 21,1 & 22,4 & 20,5 & 11,5 & 10,3 \\
\hline
\end{tabular}

Na figura 11 pode se visualizar a realização de um ensaio de toxicidade crônica com Ceriodaphnia dúbia, utilizando-se de copos de polyestireno cristal.

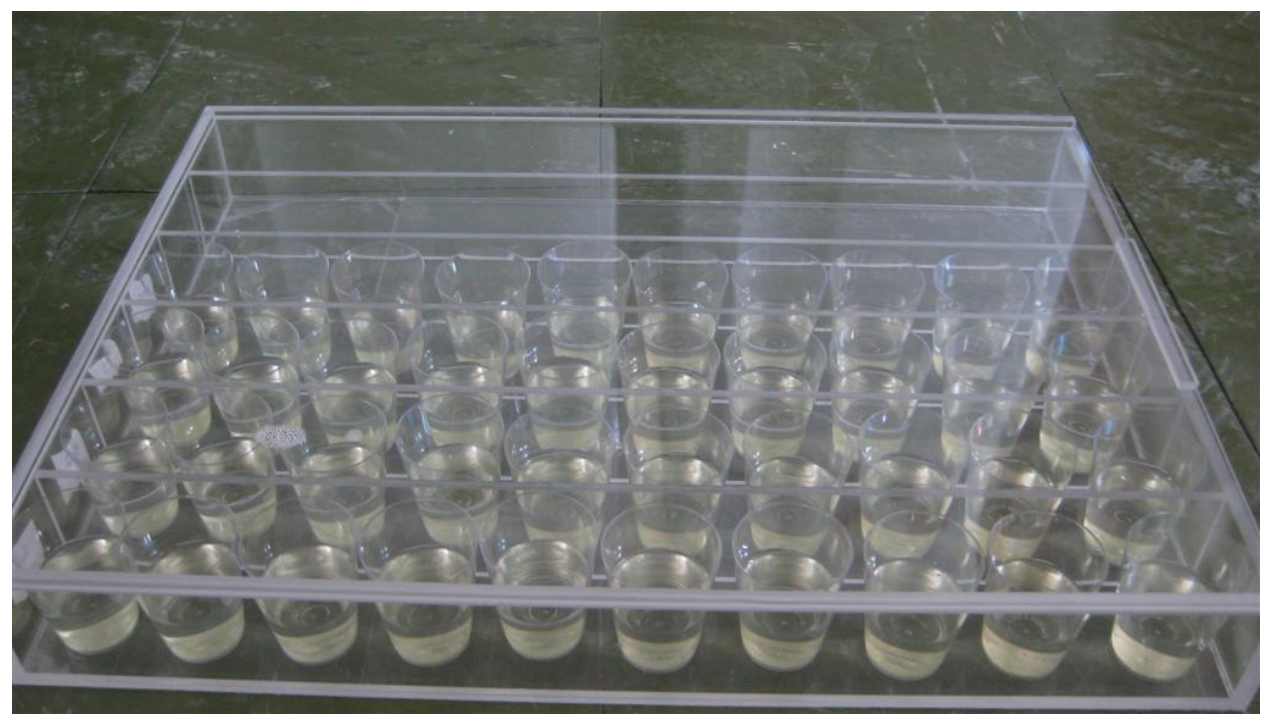

Figura 11 - Ensaio de Toxicidade crônica com Ceriodaphnia dubia

\subsubsection{Ensaios de Toxicidade aguda com Daphnia similis}

Neonatos de $D$. similis com idade entre 6 e 24 horas foram expostos às amostras de águas, sendo que a imobilidade ou morte resultantes da exposição dos organismos à amostra foram tratados para a obtenção do parâmetro final, em períodos de exposição de 24 horas e de 48 horas em condições padronizadas de ensaio. Cada um dos ensaios foi realizado juntamente com um controle, no qual vinte organismos foram expostos somente à água do cultivo, sem alimentação e permaneceram nas mesmas condições do ensaio. Esse controle não permite a perda (imobilidade ou morte) de $10 \%$ do total e foi útil para validar os ensaios com as amostras ambientais.

Esses ensaios foram realizados com amostras de todos os pontos de coleta, e amostras contidas em tubos de ensaio calibrados de $10 \mathrm{~mL}$, em 4 
replicatas por concentração. Cada tubo continha 5 organismos-teste, totalizando 20 organismos em cada concentração.

As soluções-teste foram preparadas no momento do ensaio, homogeneizadas e colocadas na incubadora para atingir a temperatura de $20^{\circ} \mathrm{C}$ antes de se colocar os organismos, como forma de evitar que esses sofressem choque térmico. Em seguida, os organismos foram adicionados e as estantes com tubos cobertas com plástico preto, evitando interferência da luz.

A leitura dos ensaios foi feita por meio da observação da impossibilidade do organismo se movimentar na coluna d'água (imobilidade). São considerados imóveis os organismos que não forem capazes de nadar em um intervalo de 15 segundos. Os resultados obtidos foram registrados em formulários padronizados.

A partir dos dados obtidos, o número de organismos imóveis nas várias concentrações de amostras que fizeram parte do teste, foi calculado o valor da CE (I) 50, 24 e 48 horas e o respectivo intervalo de confiança, utilizando-se o programa estatístico Trimmed Spearman Karber (Hamilton et al., 1977).

Mensalmente, os organismos foram avaliados em relação à sua sensibilidade a substância referência $(\mathrm{KCl})$ em concentrações de 250, 500, 750 e $1000 \mathrm{mg} / \mathrm{L}$ mais um grupo controle. Tubos de ensaio calibrados receberam $10 \mathrm{~mL}$ de amostra e os organismos-teste. Ao final de 48 horas da exposição a imobilidade foi registrada e a CE50 foi calculada com o programa estatístico Trimed Sperman Karber. Os resultados da CE50 localizam-se em média a 540 $\mathrm{mg} / \mathrm{L}$ conforme a figura 12. 


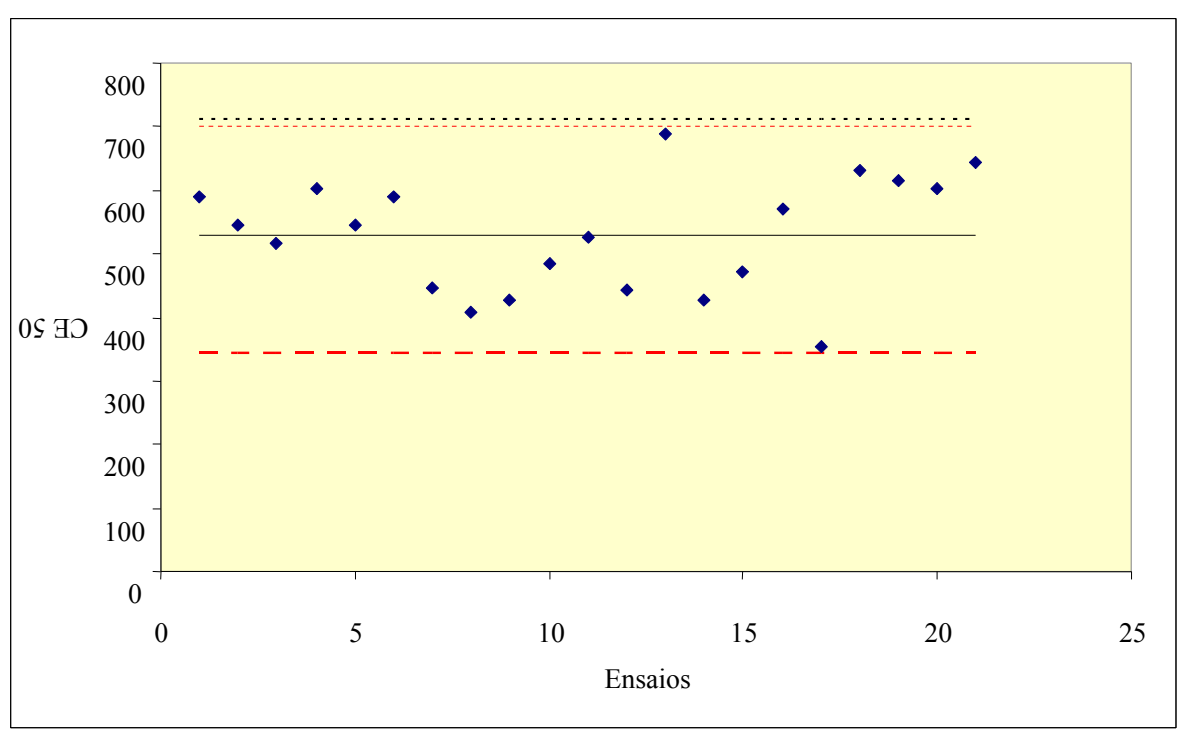

Figura 12 - Carta controle de sensibilidade de D. similis ao $\mathrm{KCl}$

\subsection{5 - Ensaios de toxicidade aguda com bactérias Vibrio fischeri}

O ensaio que utiliza a bactéria Vibrio fischeri é amplamente aplicado no monitoramento de substâncias tóxicas ambientais em muitos países e no Brasil. Vibrio fischeri são bactérias marinhas luminescentes que vivem no intestino e em órgãos luminosos de lulas (Euprymna scolopes), peixes e outros animais marinhos, estabelecendo uma relação de simbiose importante para ambas as espécies (Caetano \& Antunes, 2003).

O ensaio foi realizado com o sistema Microtox ${ }^{\circledR}$, modelo M-500 da Microbics (figura 14). O equipamento é composto por um fotômetro de precisão, câmaras de incubação e reação, que permanecem a $15^{\circ} \mathrm{C}$ e uma câmara de préresfriamento, a $3^{\circ} \mathrm{C}$. Em todos estes compartimentos, são utilizadas cubetas de borossilicato, permitindo a leitura da luminescência. Esse ensaio é normatizado pela ABNT NBR 15411-2, 2006.

As bactérias utilizadas nos ensaios são desidratadas, da marca Biolux®, UMWLT Ltda., e foram armazenadas em um freezer a $-80^{\circ} \mathrm{C}$. Antes da realização do ensaio, as bactérias foram retiradas de $-80^{\circ} \mathrm{C}$ e colocadas a $-20^{\circ} \mathrm{C}$ por 30 minutos. Para a realização do ensaio, as bactérias foram reidratadas com $350 \mu \mathrm{L}$ de uma solução de reconstituição e mantidas na câmara de préresfriamento. Após a reidratação, foram passados $100 \mu \mathrm{L}$ para outra cubeta, que

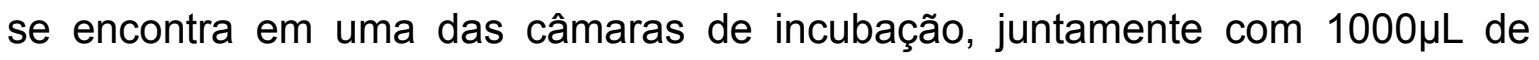


solução de reconstituição e, assim, ficando pronta para o uso. A temperatura da sala onde foram realizados os testes foi mantida entre 18 e $20^{\circ} \mathrm{C}$.

Para as amostras procedentes da ETE Novo Horizonte e das águas do Rio Jundiaí, foi feito ajuste osmótico com $0,2 \mathrm{~mL}$ de solução salina de $\mathrm{NaCl} 20 \%$, para a primeira concentração da amostra a ser utilizada no ensaio.

Os ensaios foram realizados com um controle e com as amostras nas concentrações de 10,23\%, 20,47\%, 40,95\% e 81,90\%, primeira série de cubetas. Numa segunda série de cubetas foram colocadas as soluções reagentes, que continham $100 \mu \mathrm{L}$ de bactéria. Foi realizada a leitura inicial da luminescência $\left(I_{0}\right)$, das soluções que continham somente a bactéria. Em seguida foram transferidos $900 \mu \mathrm{L}$ de cada concentração para as cubetas contendo bactéria. Transcorridos os 15 minutos de exposição da bactéria a amostra foi realizada a leitura final $\left(I_{15}\right)$.

Com base nos dados brutos das concentrações da amostra expostas e da e da perda da luminescência em função da concentração da amostra, foram calculados os valores da $\mathrm{CE}(\mathrm{I})$ 50, com auxílio de curva de regressão linear.

No final de cada conjunto de testes utilizando a bactéria, foi feita a avaliação da sensibilidade da bactéria $V$. fischeri ao fenol. Essa substância é utilizada como referência para validar os ensaios realizados. A faixa de sensibilidade do organismo ao fenol esteve entre 10,2 e 19,8 (figura 13).

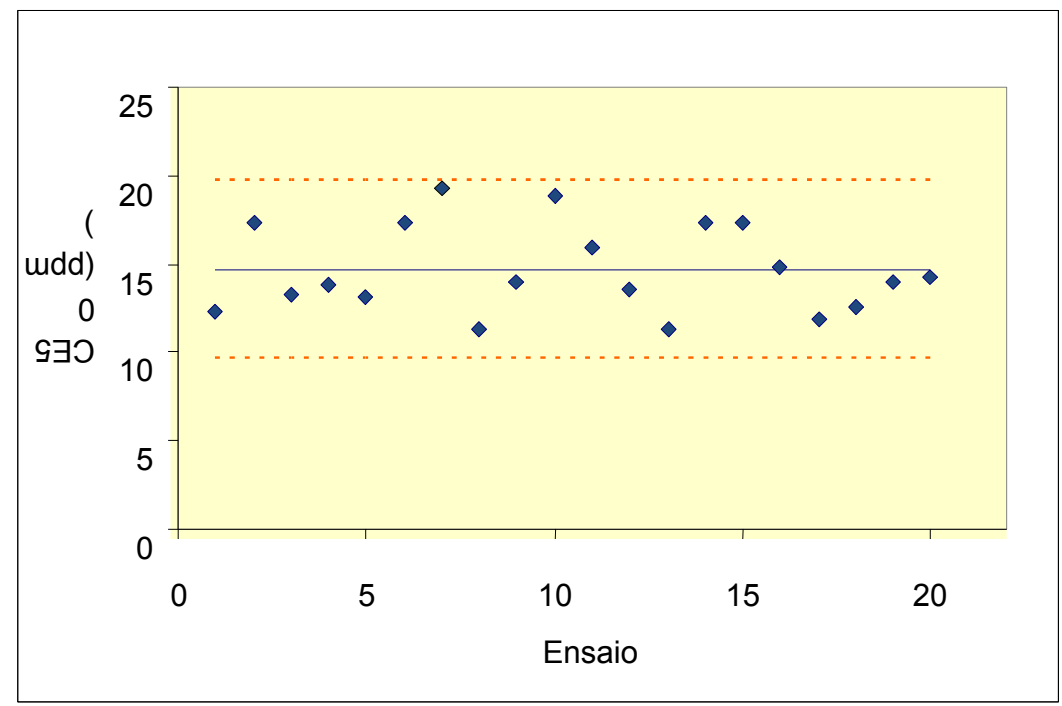

Figura 13 - Carta controle de sensibilidade de V. fischeri ao fenol 


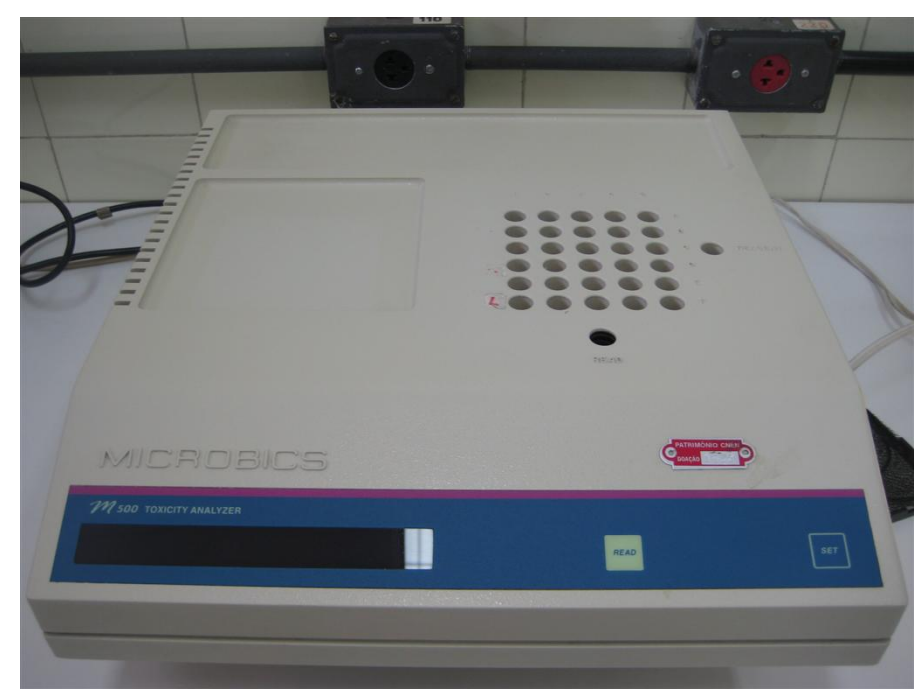

Figura 14 - Sistema Microtox®, modelo M-500 da Microbics

\subsubsection{Avaliação de Parâmetros Físico - químicos}

Os parâmetros físico-químicos da água estão diretamente relacionados à presença de matéria orgânica e inorgânica na água e influenciam a toxicidade. Os parâmetros que mais interferem na toxicidade são $\circ \mathrm{pH}$, a presença de resíduos sólidos, íons e de contaminantes propriamente ditos.

Os parâmetros $\mathrm{pH}$, temperatura e condutividade foram avaliados no momento da coleta com equipamentos do DAE.

Outros parâmetros como nitrogênio total, resíduos sólidos totais, demanda bioquímica de oxigênio (DBO) e demanda química de oxigênio (DQO) foram realizados pelo DAE S.A. e enviados em forma de relatórios mensais. 


\section{RESULTADOS}

Neste capítulo estão organizados os resultados dos ensaios de toxicidade realizados durante o estudo que compreendeu o período de junho de 2007 a agosto de 2008. Outros dados comparativos de parâmetros físicos e químicos, fornecidos pelo DAE e relatórios CETESB, também foram utilizados.

Durante o desenvolvimento do trabalho experimental, foram realizadas cinco campanhas de amostragem na ETE Novo Horizonte, Jundiaí, São Paulo. As quatro primeiras campanhas compreenderam coletas na montante da ETE (rio), duas saídas da ETE (efluente final) e jusante da ETE (rio). Na quinta campanha, foram coletadas amostras da entrada da ETE (afluentes) na chegada do emissário da cidade e na calha que leva o efluente para as lagoas de aeração, setor de mistura do efluente da cidade com efluentes recebidos por bateladas (em caminhões).

Ainda na quinta campanha, foram coletadas amostras do efluente tratado na saída da ETE e amostras pontuais, coletadas na calha de entrada das lagoas de aeração, tendo como finalidade avaliar a influência dos Efluentes Via Caminhão (EVC) nos efluentes da estação, além dos afluentes já especificados.

Embora a etapa inicial do trabalho tenha sido dedicada aos efluentes tratados e águas do rio (campanhas de 1 a 4), por motivos de ordem logística e didática, os dados da quinta campanha foram apresentados primeiro, uma vez que representam a entrada da estação.

Os resultados de toxicidade aguda dos afluentes da ETE e da mistura destes com os industriais foram apresentados na tabela 3 e nas figuras 15 e 16 . 
Tabela 3 - Resultados de toxicidade aguda em afluentes da ETE e da mistura destes com os industriais.

\begin{tabular}{|c|c|c|}
\hline $\begin{array}{c}\text { Amostra } \\
\text { Efluente do emissário } \\
\text { em agosto de 2008: }\end{array}$ & $\begin{array}{l}\text { V. fischeri } \\
\text { CE50 (\%) }\end{array}$ & $\begin{array}{l}\text { D. similis } \\
\text { CE50 (\%) }\end{array}$ \\
\hline $18 / 08$ & $6,67(5,84-7,62)$ & N.T. \\
\hline $19 / 08$ & $4,63(4,33-4,94)$ & $17,68(15,47-21,39)$ \\
\hline $20 / 08$ & $6,04(5,61-6,51)$ & $38,56(34,48-43,12)$ \\
\hline $21 / 08$ & $6,04(5,92-6,17)$ & $60,76(51,07-72,28)$ \\
\hline $22 / 08$ & $5,08(2,24-11,49)$ & $37,87(33,89-41,51)$ \\
\hline 23/08 & $8,31(4,46-15,48)$ & $31,93(27,21-37,46)$ \\
\hline $01-19 / 08^{(* *)}$ & $3,71(2,24-6,13)$ & N.T. \\
\hline $\left.02-19 / 08^{(\star \star}\right)$ & $1,26(0,24-6,44)$ & N.T. \\
\hline $03-19 / 08^{(* *)}$ & $4,42(3,98-4,91)$ & $22,42(15,13-33,23)$ \\
\hline $04-19 / 08^{(* *)}$ & $9,39(8,41-10,49)$ & $72,50(62,42-84,21)$ \\
\hline $05-19 / 08^{(* *}$ & $9,32(8,52-10,17)$ & $41,10(32,05-52,71)$ \\
\hline $\left.06-19 / 08^{(\star \star}\right)$ & $2,23(2,08-2,39)$ & $61,24(55,48-67,59)$ \\
\hline $01-20 / 08^{(* *)}$ & $3,48(3,06-3,95)$ & $18,55(14,83-23,21)$ \\
\hline $02-20 / 08^{(* *)}$ & $3,51(3,16-3,89)$ & $39,46(39,23-44,20)$ \\
\hline $\left.03-20 / 08^{(* \star}\right)$ & $7,73(7,10-8,42)$ & $43,91(32,66-59,02)$ \\
\hline $04-20 / 08^{(* *}$ & $5,62(4,87-4,48)$ & $56,15(45,43-69,39)$ \\
\hline $\left.05-20 / 08^{(* \star}\right)$ & $5,01(4,15-6,05)$ & $61,83(53,82-71,03)$ \\
\hline $06-20 / 08^{(* \star)}$ & $5,35(5,09-5,61)$ & $44,22(36,50-53,57)$ \\
\hline $01-22 / 08^{(* *)}$ & $4,40(4,01-4,82)$ & $84,35(65,15-94,21)$ \\
\hline $02-22 / 08^{(* *)}$ & $6,79(6,04-7,64)$ & $84,95(74,77-96,53)$ \\
\hline $\left.03-22 / 08^{(* *}\right)$ & $6,06(4,99-7,35)$ & $38,04(34,55-41,89)$ \\
\hline $\left.04-22 / 08^{(* \star}\right)$ & $3,13(2,88-3,39)$ & $15,52(12,35-19,52)$ \\
\hline $\left.05-22 / 08^{(\star \star}\right)$ & $4,98(4,76-5,21)$ & $33,12(27,87-39,36)$ \\
\hline $06-22 / 08^{(* *}$ & $3,49(3,40-3,57)$ & $35,36(32,87-38,03)$ \\
\hline
\end{tabular}

Vale lembrar que dentre esses resultados, encontram-se dados de seis dias de monitoramento da toxicidade do emissário (figura15), enquanto que, para o monitoramento nas calhas de condução da mistura até as lagoas, a rotina de amostragem representou três dias com seis coletas diárias, uma a cada hora, totalizando 18, cujos dados foram representados na figura 16. 


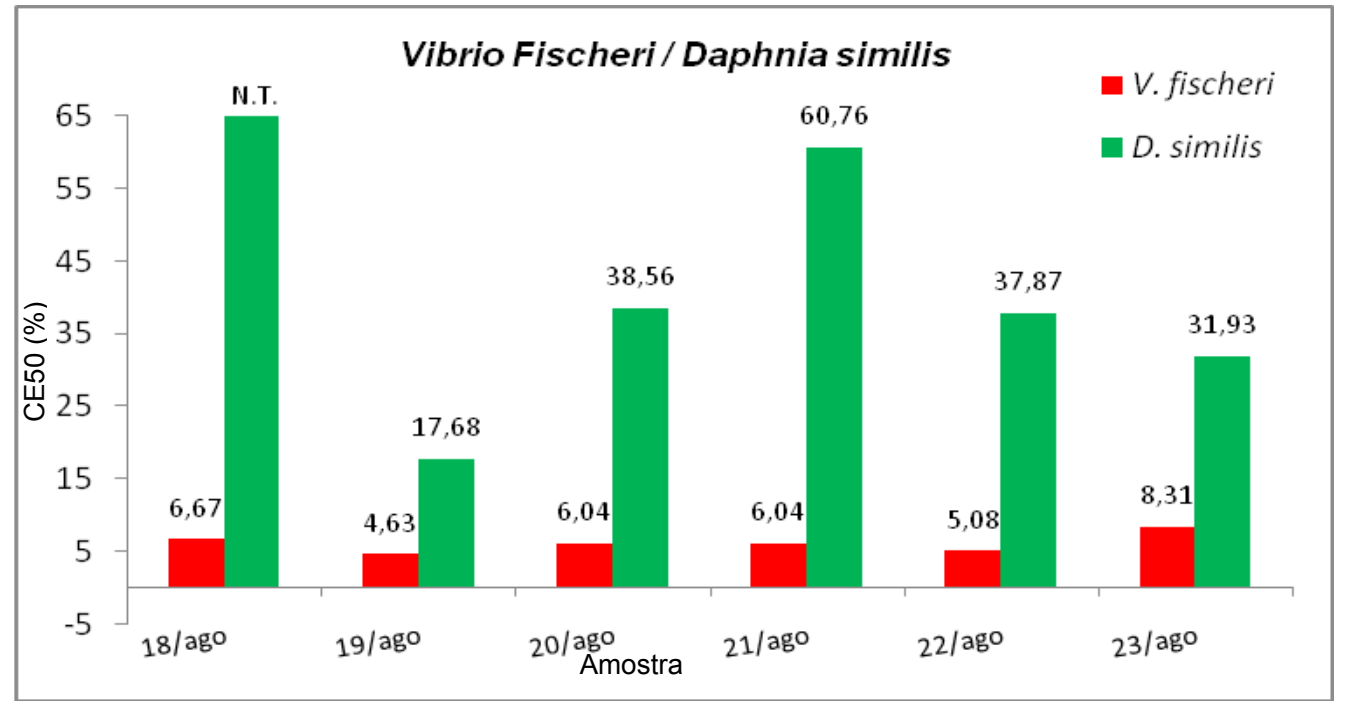

\section{N.T.= Não Tóxico}

Figura 15 - Valores de CE(i)50 obtidos com Vibrio fischeri e Daphnia similis em afluentes (amostra composta).

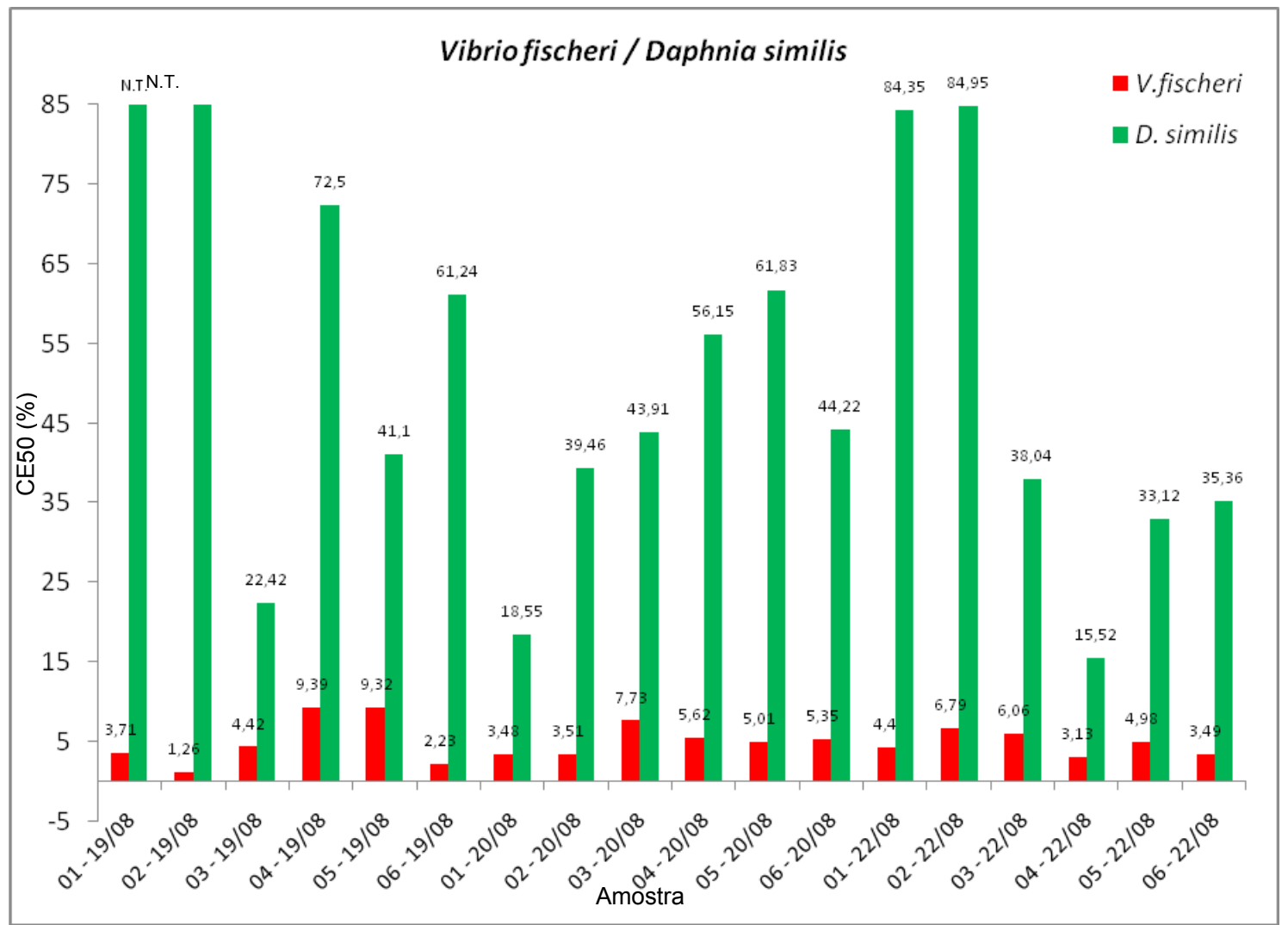

Figura 16 - Valores de CE(i)50 obtidos com Vibrio fischeri e Daphnia similis em mistura de afluentes (emissário + industrial (EVCs)) 
Os resultados obtidos nos ensaios de toxicidade aguda e crônica realizados entre a primeira e quarta campanha foram organizados nas tabelas 4 , 5 e 6 (pontos 1, 4, 5 e 6). Na tabela 4, encontram-se os resultados obtidos com bactérias luminescentes, enquanto nas tabelas 5 e 6 estão os valores obtidos com Daphnia similis e Ceriodaphnia dubia. Os valores entre parêntesis correspondem aos respectivos intervalos de confiança.

Tabela 4 - Valores de CE(i)50 obtidos com Vibrio fischeri (exposição de 15 min.) em amostras de água do rio e efluente final.

\begin{tabular}{c|cccc}
\hline $\begin{array}{c}\text { Pont } \\
\text { o }\end{array}$ & Campanha 1 & Campanha 2 & Campanha 3 & Campanha 4 \\
\hline P1 & NR & 53,55 & NT & 75,75 \\
& & $(35,65-80,42)$ & & $(72,81-78,81)$ \\
P4 & 29,46 & NR & NT & 93,70 \\
& $(21,35-36,82)$ & & & $(84,70-103,82)$ \\
P5 & NR & NT & NT & 57,45 \\
P6 & NR & 68,72 & NT & $(54,27-60,82)$ \\
& & $(53,73-87,88)$ & & $(54,11-80,87,17)$ \\
\hline
\end{tabular}

NT:Não Tóxico - NR: Não Realizado

Tabela 5 - Valores de CE(i)50 obtidos com Daphnia similis para exposição em 24 e 48 horas, em amostras de água do rio e efluente final.

\begin{tabular}{c|c|cccc}
\hline Ponto & $\begin{array}{c}\text { Exposiçã } \\
\text { o }\end{array}$ & Campanha 1 & Campanha 2 & Campanha 3 & Campanha 4 \\
\hline$P 1$ & $24 \mathrm{~h}$ & NT & IT & $\begin{array}{c}67,22 \\
(56,71-79,67) \\
55,92\end{array}$ & NT \\
& $48 \mathrm{~h}$ & NT & IT & NT \\
\hline$P 4$ & $24 \mathrm{~h}$ & NT & NR & NT & NT \\
& $48 \mathrm{~h}$ & NT & NR & NT & NT \\
\hline$P 5$ & $24 \mathrm{~h}$ & NR & $\begin{array}{c}93,06 \\
(72,33-119,73) \\
70,97\end{array}$ & NT & NT \\
& $48 \mathrm{~h}$ & NR & $(44,97-112,00)$ & NT & NT \\
\hline$P 6$ & $24 \mathrm{~h}$ & NT & IT & NT & NT \\
& $48 \mathrm{~h}$ & NT & IT & NT & NT \\
\hline
\end{tabular}


Tabela 6 - Média de nascimentos de Ceriodaphnia dubia exposta a águas do Rio Jundiaí e efluentes tratados.

\begin{tabular}{c|c|ccc}
\hline Ponto & Concentraçã & Campanh & Campanh & Campanh \\
& o & a 2 & a 3 & a 4 \\
\hline \multirow{3}{*}{ P1 } & Controle & 16,60 & 13,75 & 15,70 \\
& $50 \%$ & 9,20 & 15,25 & 13,70 \\
& $100 \%$ & 4,60 & 13,71 & 13,00 \\
\hline \multirow{3}{*}{$P 4$} & Controle & NR & 12,10 & 15,70 \\
& $50 \%$ & NR & 6,30 & 14,60 \\
& $100 \%$ & NR & 9,60 & 10,35 \\
\hline \multirow{3}{*}{$P 5$} & Controle & 15,20 & 14,90 & 17,20 \\
& $50 \%$ & 12,70 & 10,60 & 15,10 \\
& $100 \%$ & 0 & 4,50 & 9,10 \\
\hline \multirow{2}{*}{$P 6$} & Controle & 16,60 & 18,20 & 17,20 \\
& $50 \%$ & 12,00 & 18,00 & 15,50 \\
& $100 \%$ & 7,80 & 14,90 & 15,00 \\
\hline
\end{tabular}

NR: Não Realizado

Na figura 17 constam as médias de nascimento de C.dubia para amostras de água do rio e efluente final (P4 e P5).

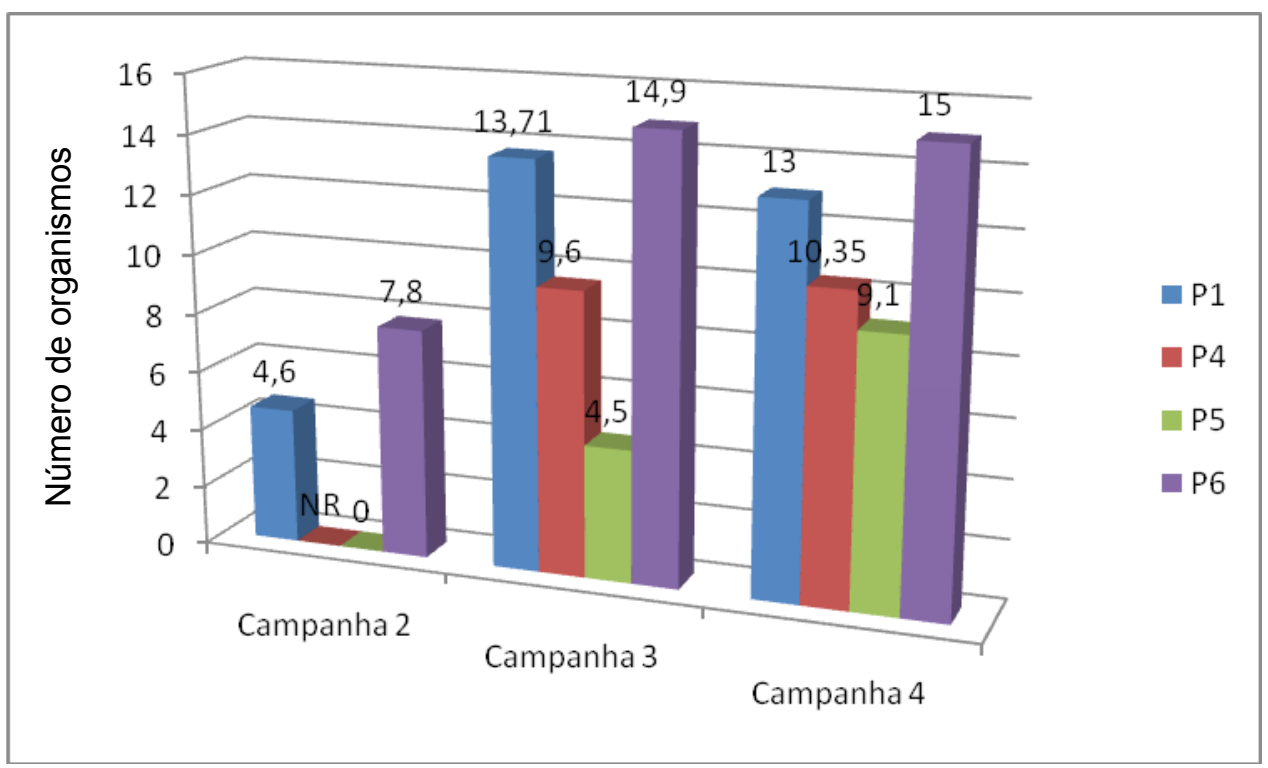

Figura 17 - média de nascimento de C. dubia em amostras de água do rio e efluente final (100\% de amostra). 
Nas tabelas 7, 8 e 9, estão representados os dados de nitrogênio total e sólidos totais, demanda bioquímica de oxigênio (DBO) e demanda química de oxigênio (DQO) em afluentes e efluentes da ETE, respectivamente. Determinações realizadas pelo DAE/S.A., em períodos de amostragem que coincidiram com a realização de ensaios ecotoxicológicos.

Tabela 7 - Nitrogênio total em águas residuárias ( $\mathrm{mg} / \mathrm{l})$

\begin{tabular}{l|cc}
\hline \multicolumn{1}{c|}{ Mês } & $\begin{array}{c}\text { Afluente ETE } \\
(\boldsymbol{P 2})\end{array}$ & $\begin{array}{c}\text { Efluente ETE } \\
\text { Saída 1 + 2 (P4 e P5) }\end{array}$ \\
\hline Junho 2007 & 25,00 & 22,00 \\
Outubro 2007 & 30,00 & 24,00 \\
Março 2008 & 21,00 & 20,00 \\
Julho 2008 & 32,00 & 24,00 \\
Agosto 2008 & 37,00 & 26,00 \\
\hline Média & 29,00 & 23,20 \\
Desvio Padrão & 6,20 & 2,28 \\
\hline
\end{tabular}

Tabela 8 - Resíduos sólidos totais em águas residuárias (mg/l)

\begin{tabular}{l|cc}
\hline Mês & $\begin{array}{c}\text { Afluente ETE } \\
\text { (P2) }\end{array}$ & $\begin{array}{c}\text { Efluente ETE } \\
\text { Saída 1 + 2 (P4 e P5) }\end{array}$ \\
\hline Junho 2007 & 1195,00 & 660,00 \\
Outubro 2007 & 1155,00 & 675,00 \\
Março 2008 & 897,00 & 516,00 \\
Julho 2008 & 920,00 & 675,00 \\
Agosto 2008 & 995,00 & 640,00 \\
\hline Média & 1032,40 & 633,20 \\
Desvio Padrão & 135,86 & 67,07 \\
\hline
\end{tabular}

Tabela 9 - Médias mensais de DBO e DQO (ton/dia).

\begin{tabular}{l|cccc}
\hline Mês & $\begin{array}{c}\text { Afluente ETE } \\
\text { (DBO) }\end{array}$ & $\begin{array}{c}\text { Efluente ETE } \\
\text { (DBO) }\end{array}$ & $\begin{array}{c}\text { Afluente ETE } \\
\text { (DQO) }\end{array}$ & $\begin{array}{c}\text { Efluente ETE } \\
\text { (DQO) }\end{array}$ \\
\hline Junho 2007 & 49,00 & 2,00 & 82,00 & 10,00 \\
Outubro 2007 & 55,00 & 2,00 & 88,00 & 10,00 \\
Março 2008 & 45,00 & 3,00 & 69,00 & 34,00
\end{tabular}




\begin{tabular}{l|cccc} 
Julho 2008 & 42,00 & 3,00 & 81,00 & 13,00 \\
Agosto 2008 & 44,00 & 3,00 & 85,00 & 11,00 \\
\hline Média & 47,00 & 2,60 & 81,00 & 15,60 \\
Desvio Pad. & 5,14 & 0,54 & 7,24 & 10,35 \\
\hline
\end{tabular}

Com relação aos efluentes industriais que são recebidos pela estação, também foi realizada pelo DAE a análise de DBO e DQO dos efluentes industriais, e os resultados da carga orgânica diária foram apresentados na tabela 10, de acordo com a data das coletas.

Tabela 10 - Volume de efluente e concentração média de DBO e DQO dos Efluentes industriais (EVCs)

\begin{tabular}{c|lccc}
\hline Campanha & Data & $\begin{array}{c}\text { Volume de } \\
\text { efluente }\left(\mathbf{m}^{3}\right)\end{array}$ & $\begin{array}{c}\text { Carga DBO } \\
(\mathbf{m g} / \mathbf{L})\end{array}$ & $\begin{array}{c}\text { Carga DQO } \\
(\mathbf{m g} / \mathbf{L})\end{array}$ \\
\hline 1 & $29 / 6 / 2007$ & $1.053,30$ & $4.715,0$ & $10.870,0$ \\
2 & $18 / 10 / 2007$ & 984,10 & $6.493,0$ & $12.456,0$ \\
3 & $25 / 3 / 2008$ & $1.832,50$ & $5.359,0$ & $20.637,0$ \\
4 & $1 / 7 / 2008$ & $1.352,80$ & - & - \\
\hline
\end{tabular}

Além dos parâmetros relacionados acima, durante todas as coletas foram realizadas instantaneamente medições de temperatura $\left({ }^{\circ} \mathrm{C}\right), \mathrm{pH}$ e condutividade $(\mu \mathrm{S} / \mathrm{cm})$ das amostras, cujos dados constam nas tabelas 11 e 12 .

Tabela 11 - Temperatura, $\mathrm{pH}$ e condutividade das amostras de água do rio e das saídas da ETE medidos na hora das coletas entre as campanhas 1 e 4.

\begin{tabular}{c|c|ccc}
\hline $\begin{array}{c}\text { Campanh } \\
\text { a }\end{array}$ & Amostr & $\begin{array}{c}\text { Temp. } \\
\left({ }^{\circ} \mathbf{C}\right)\end{array}$ & pH & $\begin{array}{c}\text { Cond. } \\
(\boldsymbol{\mu S} / \mathbf{c m})\end{array}$ \\
\hline \multirow{3}{*}{1} & P1 & 17,2 & 6,8 & 220 \\
& P4 & 20,3 & 8,3 & 715 \\
& P6 & 17,4 & 6,7 & 225 \\
\hline \multirow{3}{*}{2} & P1 & 21,5 & 6,9 & 185 \\
& P5 & 25,5 & 7,5 & 698 \\
& P6 & 22,7 & 6,8 & 196 \\
\hline & P1 & 22,9 & 6,5 & 170
\end{tabular}




\begin{tabular}{l|l|lll}
3 & P4 & 25,2 & 7,4 & 672 \\
& P5 & 25,2 & 7,2 & 725 \\
& P6 & 23,7 & 6,8 & 225 \\
\hline \multirow{3}{*}{4} & P1 & 16,3 & 6,9 & 298 \\
& P4 & 20,1 & 7,0 & 860 \\
& P5 & 19,8 & 6,9 & 815 \\
& P6 & 17,6 & 6,9 & 409 \\
\hline
\end{tabular}

Tabela 12 - Temperatura, $\mathrm{pH}$ e condutividade das amostras (P3) aferidos na hora das coletas da campanha 5 .

\begin{tabular}{|c|c|c|c|c|c|}
\hline \multirow[b]{2}{*}{ Data } & \multicolumn{2}{|c|}{ Amostr } & \multirow[b]{2}{*}{$\begin{array}{c}\text { Temp. } \\
\left.\text { ( }{ }^{\circ} \mathrm{C}\right)\end{array}$} & \multirow[b]{2}{*}{$p H$} & \multirow[b]{2}{*}{$\begin{array}{l}\text { Cond. } \\
(\mu S / \mathrm{cm})\end{array}$} \\
\hline & $a$ & Hora & & & \\
\hline \multirow[b]{2}{*}{$19 / 8 / 200$} & $1 / 6$ & $10: 00$ & 23,0 & 6,5 & 750 \\
\hline & $2 / 6$ & $11: 00$ & 22,5 & 6,3 & 720 \\
\hline \multirow[t]{4}{*}{8} & $3 / 6$ & $12: 00$ & 22,6 & 6,3 & 790 \\
\hline & $4 / 6$ & $13: 00$ & 22,8 & 6,4 & 743 \\
\hline & $5 / 6$ & $14: 00$ & 24,0 & 7,4 & 1560 \\
\hline & $6 / 6$ & $15: 00$ & 23,5 & 6,9 & 890 \\
\hline \multirow[b]{3}{*}{$20 / 8 / 200$} & $1 / 6$ & $10: 00$ & 22,3 & 6,7 & 1185 \\
\hline & $2 / 6$ & $11: 00$ & 22,3 & 6,5 & 760 \\
\hline & & & & & \\
\hline \multirow[t]{5}{*}{8} & $3 / 6$ & $12: 00$ & 22,3 & 6,6 & 975 \\
\hline & $4 / 6$ & $13: 00$ & 22,6 & 6,3 & 777 \\
\hline & $5 / 6$ & $14: 00$ & 23,7 & 6,5 & 901 \\
\hline & $6 / 6$ & $15: 00$ & 23,4 & 6,3 & 845 \\
\hline & $1 / 6$ & $10: 00$ & 24,3 & 6,6 & 748 \\
\hline
\end{tabular}




\begin{tabular}{c|c|cccc}
$22 / 8 / 200$ & $2 / 6$ & $11: 00$ & 23,8 & 6,5 & 718 \\
8 & & & & & \\
& $3 / 6$ & $12: 00$ & 24,0 & 6,6 & 805 \\
& $4 / 6$ & $13: 00$ & 23,7 & 6,3 & 790 \\
& $5 / 6$ & $14: 00$ & 24,3 & 6,9 & 1560 \\
& $6 / 6$ & $15: 00$ & 24,8 & 7,1 & 1380 \\
\hline
\end{tabular}

Para melhor caracterizar os efluentes descarregados via caminhão na ETE Novo Horizonte, foi organizada a tabela 13 que demonstra a variedade de efluentes, indicados por atividades industriais. Neste caso, são os caminhões recebidos por ocasião da Terceira campanha.

Tabela 13 - Tipos de EVC e cargas descarregadas no dia 25/03/2008.

\begin{tabular}{|c|c|c|c|c|c|}
\hline Tipo de Material & Local & $\begin{array}{c}\text { Volum } \\
e \\
(m 3) \\
\end{array}$ & $\begin{array}{c}\text { DBO Total } \\
(\mathrm{mg} / \mathrm{L})\end{array}$ & $\begin{array}{c}\text { DQO Total } \\
(\mathrm{mg} / \mathrm{L})\end{array}$ & $\begin{array}{c}\text { Relação } \\
(D B O / D Q O \\
)\end{array}$ \\
\hline Química & Itupeva & 9,60 & $2.109,8$ & 6.850 & 0,308 \\
\hline Biocombustível & Charqueada & 28,80 & $28.933,2$ & 42.300 & 0,684 \\
\hline Cosmética / farmacêutica & Sorocaba & 9,60 & $36.180,0$ & 45.000 & 0,804 \\
\hline Chorume & Paulínia & 27,00 & $2.035,2$ & 2.788 & 0,730 \\
\hline Chorume & Bragança Paulista & 25,20 & 765,8 & 1.365 & 0,561 \\
\hline Resíduo hospitalar / domiciliar & Mogi das Cruzes & 189,00 & $2.132,7$ & 8.813 & 0,242 \\
\hline Chorume & Itu & 12,60 & $1.230,3$ & 3.325 & 0,370 \\
\hline Esgoto & Itu & 329,80 & $2.274,0$ & 3.650 & 0,623 \\
\hline Metalúrgica & Jundiaí & 6,40 & 92,9 & 1.475 & 0,063 \\
\hline Química & Nova Odessa & 23,76 & $5.199,2$ & 18.975 & 0,274 \\
\hline Cosméticos & Louveira & 19,20 & $16.944,4$ & 29.675 & 0,571 \\
\hline Alimentícia & Valinhos & 5,60 & 309,7 & 487 & 0,636 \\
\hline Metalúrgica & Jundiaí & 9,60 & $3.031,3$ & 4.406 & 0,688 \\
\hline Chorume & Hortolândia & 24,30 & 44,5 & 204 & 0,218 \\
\hline Cosméticos & Louveira & 34,40 & $21.812,2$ & 64.533 & 0,338 \\
\hline Quimica & Itupeva & 16,00 & $\underline{0,0}$ & $\underline{251.000}$ & \\
\hline Cosmética / farmacêutica & Santana do Parnaíba & 10,40 & $2.468,9$ & 5.450 & 0,453 \\
\hline Esgoto & Amparo & 27,00 & 210,0 & 4.200 & 0,050 \\
\hline Resíduos domésticos industriais & São Paulo & 22,40 & 270,6 & 660 & 0,410 \\
\hline Construtora & Barueri & 34,80 & 712,5 & 2.375 & 0,300 \\
\hline Cosméticos & Louveira & 9,60 & $3.074,5$ & 5.500 & 0,559 \\
\hline Climatização & Itatiba & 48,00 & 22,0 & 115 & 0,191 \\
\hline
\end{tabular}




\begin{tabular}{l|l|c|c|c|c}
\hline Automotiva & Itatiba & 9,60 & 21,4 & 315 & 0,068 \\
\hline
\end{tabular}

Na tabela 14, constam os dados médios entre os anos de 2006 e 2009 (até o mês de março) da carga de demanda bioquímica de oxigênio (DBO) e demanda química de oxigênio (DQO) na entrada da ETE e na saída da ETE a fim de avaliar sua eficiência de remoção de carga orgânica.

Tabela 14 - Médias anuais de DBO e DQO na entrada e saída da ETE (em toneladas)

\begin{tabular}{c|cccc}
\hline \multicolumn{1}{c}{ Ano } & $\begin{array}{c}\text { DBO } \\
\text { entrada }\end{array}$ & $\begin{array}{c}\text { DBO } \\
\text { saída }\end{array}$ & $\begin{array}{c}\text { DQO } \\
\text { entrada }\end{array}$ & $\begin{array}{c}\text { DQO } \\
\text { saída }\end{array}$ \\
\hline 2006 & 1408,07 & 81,35 & 2533,18 & 335,79 \\
2007 & 1481,36 & 77,20 & 2674,87 & 349,72 \\
2008 & 1381,83 & 74,43 & 2637,80 & 369,22 \\
2009 & 1017,97 & 56,47 & 1958,03 & 288,53 \\
\hline
\end{tabular}

A CETESB, por meio de seus relatórios anuais, faz um controle da qualidade das águas dos rios, que inclui os dados de oxigênio dissolvido na água (OD), demanda bioquímica de oxigênio e demanda química de oxigênio em 3 pontos do rio Jundiaí. Esses dados foram organizados na tabela 15. De acordo com os dados apresentados na tabela 15 o trecho do rio enquadrado o rio como classe 4 segundo a resolução 357 do CONAMA.

Tabela 15 - Médias anuais de OD, DBO e DQO no rio Jundiaí, segundo a CETESB

\begin{tabular}{c|cccc}
\hline Ponto & Ano & OD $\mathbf{~} \mathbf{g} / \mathbf{L}$ & $\mathbf{D B O} \mathbf{~} \mathbf{g} / \mathbf{L}$ & $\mathbf{D Q O} \mathbf{~} \mathbf{g} / \mathbf{L}$ \\
\hline \multirow{4}{*}{ JUNA02020 } & 2000 & 7,20 & 5,00 & 22,00 \\
(30 km a montante) & 2001 & 5,90 & 6,50 & 23,00 \\
& 2003 & 5,40 & 7,50 & 35,00 \\
& 2005 & 4,25 & 14,50 & $<50$ \\
& 2007 & 5,55 & 14,50 & $<50$ \\
\hline & 2000 & 4,30 & 19,50 & 50,00
\end{tabular}




\begin{tabular}{c|cccc} 
JUNA04270 & 2001 & 3,80 & 25,00 & 52,50 \\
(30 km a Jusante) & 2003 & 2,75 & 25,50 & 65,50 \\
& 2005 & 4,60 & 18,00 & $<50$ \\
& 2007 & 5,35 & 14,00 & $<50$ \\
\hline \multirow{3}{*}{ JUNA04900 } & 2000 & 1,40 & 54,50 & 125,00 \\
(30 km a Jusante) & 2001 & 0,20 & 43,00 & 121,00 \\
& 2003 & 0,10 & 76,50 & 170,00 \\
& 2005 & 1,20 & 34,00 & 98,00 \\
& 2007 & 2,10 & 29,00 & 75,00 \\
\hline
\end{tabular}

De acordo com os relatórios da CETESB de 2006 e 2007, os pontos representados na tabela 16 constam de dados de OD, DBO e DQO de águas do rio Jundiaí. Estes dados são mais relevantes ao estudo em particular, pois os pontos localizam-se a montante e a jusante da ETE Novo Horizonte.

Tabela 16 - Médias anuais de OD, DBO, DQO em pontos a montante e jusante da ETE.

\begin{tabular}{c|cccc}
\hline \multicolumn{1}{c}{$\begin{array}{c}\text { Ponto } \\
\text { Ponto }\end{array}$} & $\begin{array}{c}\text { OD } \\
(\boldsymbol{m g} / \mathbf{L})\end{array}$ & $\begin{array}{c}\boldsymbol{D B O} \\
(\mathbf{m g} / \mathbf{L})\end{array}$ & $\begin{array}{c}\boldsymbol{D Q O} \\
(\mathbf{m g} / \mathbf{L})\end{array}$ \\
\hline JUNA 2100 & 2006 & 3,70 & 15,00 & $<50$ \\
(20 Km a montante) & 2007 & 3,50 & 27,83 & $<50$ \\
\hline JUNA 4150 & 2006 & 0,65 & 81,50 & 149,00 \\
(15 Km a montante) & 2007 & 0,85 & 84,60 & 135,16 \\
\hline JUNA 4190 & 2006 & 2,30 & 12,00 & $<50$ \\
(15 Km a jusante) & 2007 & 1,68 & 49,00 & $<50$ \\
\hline JUNA 4200 & 2006 & 1,75 & 15,00 & $<50$ \\
(25 Km a jusante) & 2007 & 2,01 & 14,50 & $<50$ \\
\hline
\end{tabular}

Outro dado importante que influencia nas estações de tratamento de esgoto é a pluviosidade, pois faz com que os efluentes sejam diluídos, alterando a toxicidade e os parâmetros físico-químicos. Dessa forma, em condições excessivas de chuva os operadores da ETE abrem suas comportas para liberar o efluente ao rio. A cidade de Jundiaí tem pluviosidade média anual de 1.385,2 mm, enquanto que a pluviosidade dos meses em que foram realizadas as coletas está representa na tabela 17. 
Tabela 17 - Pluviosidade total nos meses de amostragem

\begin{tabular}{r|c}
\multicolumn{1}{c|}{ Mês } & $\begin{array}{c}\text { Volume } \\
(\mathbf{m m})\end{array}$ \\
\hline Junho de 2007 & 45 \\
Outubro de2007 & 77 \\
Março de 2008 & 171 \\
Julho de 2008 & 0 \\
Agosto de 2008 & 90 \\
\hline
\end{tabular}

\section{DISCUSSÃO}

A partir dos valores de toxicidade aguda apresentados na figura $15 \mathrm{e}$ na tabela 3, foi possível observar que as amostras do emissário da cidade (P2) foram muito tóxicas para $V$. fischeri, bem como para $D$. similis. Esses valores de CE(i) 50 variaram entre $4,63 \%$ e $8,31 \%$ para $V$. fischeri, enquanto que para $D$. similis os valores variaram entre $17,68 \%$ e $60,76 \%$. Somente a amostra do dia 18/08 apresentou comportamento diferente em relação ao grupo, pois enquanto elevada toxicidade foi determinada para o primeiro organismo-teste, ausência de toxicidade foi observada para $D$. similis.

Lembrando que P1 fica à montante da ETE, P2 na entrada da ETE, P3 na calha de acesso às lagoas de aeração, P4 e P5 nas saídas da ETE e P6 à jusante da ETE.

Bulich (1992) estabeleceu um sistema de classificação para resultados de toxicidade aguda, onde, CE50 < 25\% muito tóxica; CE50 25-50\% tóxica; CE50 $51-75 \%$ moderadamente tóxica; CE50 $>75 \%$ levemente tóxica. Borrely (2001) apresentou outro sistema baseado nos valores de efeito gama.

De acordo com a figura 16, que representa o ponto $\mathrm{P} 3$, os valores de CE(i) 50 para $V$. fischeri variaram entre $1,26 \%$ e $9,39 \%$, e entre $15,52 \%$ e $84,95 \%$ para $D$. similis. Em duas amostras coletadas no dia 19 de agosto, o afluente resultou em não tóxico para $D$. similis e muito tóxico para $V$. fischeri. Cabe ressaltar que este local indica a mistura entre os efluentes que chegam ao emissário da cidade com os efluentes industriais, que juntos representaram os afluentes da estação. 
Possivelmente esses resultados que foram contraditórios, embora em baixa freqüência, podem sugerir que ocorreu grande diversidade de contaminantes e diferentes grupos de compostos orgânicos.

Com relação aos efluentes tratados na ETE Novo Horizonte que são lançados no rio Jundiaí, os ensaios de toxicidade aguda realizados com $V$. fischeri nas amostras P4 e P5 (saídas 1 e 2), apresentaram baixa freqüência de efeito agudo, porém uma das amostras teve um comportamento diferente na primeira campanha (P4), com valor de CE(I)50 $=29,46 \%$ (tabela 4 ).

Dos resultados organizados na tabela 5 , foi possível observar que para $D$. similis as amostras de efluente tratado resultaram em ausência de toxicidade aguda, com exceção do ponto 5 que, na segunda campanha, cuja CE(i)50 48h encontrada foi de $70,97 \%(44,97-112,00)$. Foram considerados indícios de toxicidade aguda (IT) quando ocorreu morte superior a $20 \%$ dos organismos expostos somente na amostra não diluída, ou seja, 100\% da amostra.

Ainda com relação ao efluente final da ETE, foram realizados ensaios de toxicidade crônica com C. dubia nos dois pontos de saída nas concentrações de $50 \%$ e $100 \%$ da amostra. Foram obtidos efeitos significativos para a reprodução de $C$. dubia nas campanhas 2, 3 e 4, sendo que o efluente da saída 2 (P5) apresentou-se pior, principalmente na segunda campanha, na qual $100 \%$ da amostra resultou em morte de todos os organismos (tabela 6). Possivelmente, residuais de contaminantes e subprodutos da biodegradação, que podem ser mais tóxicos, estavam contidos nos efluentes da saída 2 .

Ao analisar os resultados dos pontos de coleta de água do rio Jundiaí P1 e P6 (montante e jusante da ETE), foi possível notar que na campanha 2 e 4 , as amostras apresentaram toxicidade aguda para $V$. fischeri (tabela 4), reforçando a má qualidade das águas do rio. Comparando esses resultados com os pontos de saída da ETE pôde-se observar que apresentaram toxicidade semelhante, com exceção do ponto 4 na primeira campanha. Nessa ocasião, o efluente da estação apresentou CE(i)50= 29,46\% (18,83-31,12).

Para $D$. similis, que tem seus resultados na tabela 5 , as águas do rio apresentam maior toxicidade à montante da ETE, sendo que campanha 2 obtevese indícios de toxicidade (IT) e na campanha $3, \operatorname{CE}(\mathrm{i}) 50=55,92(39,43-79,30)$. Para o ponto à jusante, foram encontrados indícios de toxicidade em uma das campanhas. Fazendo uma comparação desses resultados com os resultados dos 
pontos de saída da ETE, as águas do rio apresentaram toxicidade.

Por outro lado, amostras não tóxicas para $V$. fischeri apresentaram algum sinal de efeito para $D$. similis (P5 e P1) nas campanhas 2 e 3 , respectivamente. Esses resultados sugerem que existem resíduos de compostos nos efluentes e/ou subprodutos de compostos orgânicos que afetaram os organismos aquáticos.

Os resultados de toxicidade crônica que constam da tabela 6 reforçam os indícios de toxicidade obtidos nos ensaios que avaliaram efeito agudo. Neste caso, os piores efeitos (menor número de neonatos obtidos) foram observados nas amostras de água do rio à montante $(4,60)$ e à jusante $(7,80)$, ambos na mesma campanha 2. A água do rio antes de passar pela ETE já mostrou efeito na reprodução do organismo-teste (C. dubia) quando o ensaio foi realizado em $50 \%$ de amostra, indicando que o rio já se apresenta com impactos que podem afetar a biota mesmo antes de receber o efluente da ETE Novo Horizonte. A figura 17 apresenta uma comparação entre nascimento de organismos na presença dessas amostras.

A resolução 357 do CONAMA estabelece padrões de lançamento de efluentes e ressalta que estes somente poderão ser lançados, direta ou indiretamente, nos corpos de água, após o devido tratamento e desde que obedeçam as condições, padrões e exigências dispostos na resolução. Entre esses padrões constam parâmetros físico-químicos e ensaios ecotoxicológicos.

Contaminantes de diversas origens podem estar associados aos efeitos biológicos acima demonstrados, como os resíduos sólidos (dissolvidos ou suspensos), o nitrogênio (nitrito e amônia) e a matéria orgânica em geral. A estação de tratamento de esgotos tem o papel de reduzir as cargas destes poluentes antes de lançar seu efluente no rio.

Sabe-se que os esgotos sanitários são as principais fontes de nitrogênio na água, sendo os compostos de nitrogênio nutrientes para processos biológicos. Depois do carbono, o nitrogênio é o elemento mais exigido pelas células, além do fósforo. O despejo de nitrogênio em águas naturais provoca enriquecimento do meio, favorecendo o crescimento de algas e causando eutrofização (Piveli, 2006).

O DAE Água e Esgoto S.A. realiza o monitoramento de diversos parâmetros na ETE e um deles é o nitrogênio total. Os dados da entrada e saída 
da ETE e suas médias mensais foram apresentados na tabela 7. Esses dados coincidem com os meses em que foram realizadas as coletas de amostras para os ensaios de toxicidade.

Dos resultados apresentados apenas no mês de março de 2008, o valor está conforme permitido pelo CONAMA (max. 20,0 mg/L). Foi possível observar que o nitrogênio total no efluente ainda é muito elevado, concluindo que a eficiência de remoção de Nitrogênio da ETE é baixa.

De acordo com a tabela 8 , a quantidade de sólidos totais é reduzida quase à metade após passagem pelo tratamento de esgotos. Os sólidos estão diretamente ligados à toxicidade, pois os organismos $D$. similis e $C$. dubia são filtradores de água doce, e a presença de sólidos pode afetar sua vida e reprodução.

A Demanda Bioquímica de Oxigênio (DBO) fornece informações sobre a fração dos compostos biodegradáveis presentes no efluente; é muito utilizada para avaliar o potencial poluidor de efluentes domésticos e industriais em termos de consumo de oxigênio, portanto, quanto maior a DBO, mais poluída é a água. $A$ Demanda Química de Oxigênio (DQO) é empregada para avaliar a carga orgânica em águas superficiais e residuárias passíveis de serem consumidas em oxidações. Durante essa análise são utilizados métodos de oxidação química empregando-se um reagente fortemente oxidante como o dicromato de potássio $\left(\mathrm{K}_{2} \mathrm{Cr}_{2} \mathrm{O}_{7}\right)$ (Rocha et.al., 2009).

A relação entre a DBO e a DQO em amostras de efluentes é bastante utilizada nas previsões das condições de biodegradabilidade (facilidade ou dificuldade) dos despejos. Sabe-se que o poder de oxidação do dicromato de potássio é maior do que da ação de microrganismos. Assim, os valores de DQO de uma amostra são superiores aos de DBO. Como na DBO mede-se a fração biodegradável, quanto mais este valor se aproximar da DQO significa que mais facilmente biodegradável será o efluente (1/1). Valores muito elevados dessa relação indicam possibilidade de problemas no tratamento biológico, uma vez que a fração biodegradável torna-se pequena; há também a possibilidade do tratamento biológico ser prejudicado pelo efeito tóxico da fração não biodegradável sobre os microrganismos (Piveli, 2006).

Na tabela 9, estão os resultados médios de DBO e DQO em afluentes e águas residuárias da ETE nos meses em que foram realizadas coletas para 
ensaios de toxicidade. Observou-se grande eficiência de redução da carga de DBO e DQO, podendo calcular uma remoção média de $94,46 \%$ de carga orgânica.

A contribuição em carga orgânica dos efluentes industriais consta na tabela 10, em que estão organizados o volume descarregado nos dia de coleta e sua carga de DBO e DQO em mg/L. Os dados revelaram grande contribuição em carga orgânica dos efluentes industriais, caixas de gordura e fossas sépticas, sendo que na segunda campanha houve o maior valor de DBO $(6.493,0 \mathrm{mg} / \mathrm{L}) \mathrm{e}$ na terceira campanha, o maior valor de DQO (12.456,0 mg/L), enquanto que na quarta campanha tem-se somente o valor do volume descarregado.

Nas tabelas 11 e 12, nas quais estão os dados de temperatura, $\mathrm{pH}$ e condutividade das amostras coletadas, observou-se que a temperatura das águas do rio são mais baixas que a temperatura das amostras coletadas na ETE. A temperatura tem papel importante no meio aquático, condicionando as influências de uma série de parâmetros físico-químicos. Com a mudança da temperatura temos alterações na viscosidade, condutividade, compressibilidade, aceleração das reações bioquímicas e de decomposição de compostos orgânicos. Os organismos aquáticos também são influenciados pela temperatura, pois possuem limites de tolerância térmica superior e inferior, temperaturas ótimas para crescimento, limites de temperatura para migração, desova e incubação do ovo (CETESB, 1993). O despejo de efluentes pode causar um desequilíbrio nas variações de temperatura, por isso na resolução 357 do CONAMA consta que no lançamento dos efluentes no rio, a temperatura não deve estar acima dos $40^{\circ} \mathrm{C}$.

Ainda nas tabelas 11 e 12, o pH das amostras coletadas na ETE é mais alto que em águas do rio, possivelmente devido aos efluentes industriais. $\mathrm{O} p \mathrm{H}$ exerce influência sobre a fisiologia de diversas espécies da biota aquática e também nas reações químicas que ocorrem neste meio, podendo contribuir para a precipitação de elementos químicos tóxicos e também interferir na solubilidade de nutrientes. A resolução 357 do CONAMA estabelece pH entre 5 e 9 para os lançamentos (Piveli, 2006).

A condutividade é expressão numérica da capacidade de uma água conduzir uma corrente elétrica. Este parâmetro fornece indicação de modificações na composição da água, especialmente na sua concentração mineral (íons dissolvidos). Quanto maior for a quantidade de íons dissolvidos, maior será a 
condutividade elétrica da água (CETESB, 1993). Os valores de condutividade apresentados na tabela 11 mostraram valores superiores para a saída da ETE em relação ás águas do rio, pois na ETE há grande quantidade de matéria orgânica e compostos químicos.

A partir das informações que constam da Tabela 13, pode-se observar que num dia de recebimento de efluentes via caminhão, diversos municípios acabam enviando efluentes que, depois de tratados, passam a ser incorporados pelo rio Jundiaí. Nessa ocasião, considerando somente chorume de aterros sanitários oriundos das cidades de Paulínia, Bragança Paulista, Itu e Hortolândia, com volumes que variaram entre $12,60 \mathrm{~m}^{3}$ até $27 \mathrm{~m}^{3}$. Das demais atividades que destinaram resíduos para a ETE Novo Horizonte nessa mesma data foram domicílios, hospitais, metalúrgicas, indústrias químicas, construtoras entre outras, cujos contaminantes são os mais diversificados quanto possível. Cabe ressaltar a frequência de resíduos de indústria de cosméticos que também aparece entre aquelas cujos valores de DBO e DQO foram os mais elevados.

$\mathrm{Na}$ indústria química em destaque, o valor de DBO foi zero, provavelmente, em razão de o efluente ser tão tóxico que as bactérias presentes no ensaio morreram, inviabilizando a obtenção de resultado.

Na tabela 14, estão as médias dos anos de 2006, 2007, 2008 e 2009 (até o mês de março) de carga de DBO e DQO na entrada e saída da ETE, em dados fornecidos pelo DAE. Estes resultados permitem concluir que a ETE teve uma eficiência média anual de: 94,22\%; 94,78\%; 94,61\% e 94,45\% para DBO em 2006, 2007, 2008 e 2009 (até março), respectivamente. Para os valores mais elevados de DQO em 2007, foi obtida uma eficiência de $86,92 \%$ de redução.

A fim de se avaliar a evolução da qualidade das águas do rio, na tabela 15 constam os resultados de ensaios realizados pela CETESB em seus relatórios anuais dos parâmetros OD, DBO e DQO. Pode-se observar que a quantidade de oxigênio dissolvido diminui a cada ponto, enquanto que os valores de DBO e DQO aumentam frisando piora na qualidade das águas da cabeceira até sua foz.

Ainda com dados dos relatórios da CETESB (2006 e 2007), na tabela 16 constam quatro pontos em que dois se localizam à montante da ETE (Jundiaí) e dois a jusante (Itupeva). Entre o primeiro e o segundo ponto, há grande queda de oxigênio dissolvido, que pode ser resultado da falta de tratamento de esgotos na cidade de Várzea Paulista, o que aumenta a matéria orgânica em suas águas, 
resultando em aumento de DBO e DQO de 543\% em DBO para o ano de 2006, e aumento de $303 \%$ para o ano de 2007.

A ETE Novo Horizonte entrou em operação em 1998 com eficiência de remoção de carga orgânica importante: 94,64\% de remoção para a DBO e $86,26 \%$ para a redução de DQO. Entretanto, a condição sanitária do Rio Jundiaí ainda é ruim.

Apesar disso desde o ano de 2000, a qualidade das águas do rio Jundiaí vem piorando devido ao aumento populacional e econômico das cidades em seu entorno, associado à falta de um sistema de tratamento de esgotos nas cidades de Campo Limpo Paulista, Várzea Paulista e Itupeva, que acabam lançando seus esgotos diretamente no rio.

Com relação ao rio, Além Sobrinho, 1976 realizou um estudo para fixar parâmetros no trecho de classe 4 do rio Jundiaí. Nessa época, o rio já apresentava OD entre 6,8 e 0,9 mg/L, e DBO entre 1,0 e 126,0 mg/L, demonstrando piora da qualidade da água desde sua cabeceira até sua foz. Com essa piora na qualidade das águas, o rio Jundiaí, há muitos, anos também contribui para a degradação do rio Tietê, por ser um de seus afluentes.

Não foram encontrados registros anteriores de toxicidade para a ETE Novo Horizonte, mas diversos autores reportaram seus resultados obtidos para outras estações de tratamento. Antes mesmo do início de operação da ETE, Suzano Gerardi-Goldstein et. al (1983) realizou um estudo ecotoxicológico em 20 indústrias da região de Suzano e Mogi das Cruzes (cidades atendidas pela ETE Suzano) para caracterizar a toxicidade dos efluentes que futuramente chegariam na ETE. Enquanto que Bertoletti et. al. (1989) mostrou que $79 \%$ dos efluentes domésticos e $62 \%$ dos efluentes industriais apresentavam efeitos tóxicos mesmo após os tratamentos para remoção de poluentes convencionais e que $43 \%$ dos domésticos e $46 \%$ dos efluentes industriais tinham potencial para causar efeitos tóxicos nos mais diferentes corpos receptores.

Essa mesma ETE Suzano foi monitorada para toxicidade em outros períodos: Zagatto et. al. (1992) avaliou a eficiência de redução de toxicidade da ETE Suzano e seu impacto no corpo receptor (Rio Tietê). A ETE Suzano também opera por meio de sistema de lodos ativados, e recebia cerca de $55 \%$ de efluentes domésticos e $45 \%$ de efluentes industriais. Foram utilizados testes de toxicidade crônica com Daphnia similis e seus resultados afirmam que a ETE 
reduz a toxicidade de seus efluentes, porém há toxicidade remanescente, o que causa impacto à biota do corpo receptor. Borrely, (2001) determinou a toxicidade do efluente final da ETE Suzano com D. similis e V. fischeri . Hamada (2008) avaliou a eficiência do sistema de tratamento de esgotos e efluentes da ETE Suzano e seu impacto sobre o rio Tietê utilizando Daphnia similis, Ceriodaphnia dubia e Vibrio fischeri. Seus resultados mostram que há redução na toxicidade após o tratamento, porém ainda há impacto sobre a biota do rio.

Sapia \& Morita (2002) discutiram as limitações das estações de tratamento de esgoto em receber efluentes de origem industrial, pois os mesmos podem causar corrosão, incrustação, inflamabilidade, explosão e danos à saúde e segurança dos operadores. O sistema de coleta e transporte de esgotos sanitários, bem como problemas de inibição aos processos biológicos de tratamento, volatilização em diferentes unidades da estação, geração de lodo com características perigosas e toxicidade à vida aquática, e concluiram que antes desses despejos, seus compostos devem ser caracterizados.

Com relação à forte presença de efluentes de atividades farmacêuticas e de cosméticos, é possível afirmar que esses efluentes contêm substancial quantidade de surfactantes e desinfetantes, produtos que são críticos para o ambiente aquático e que conhecidamente representam danos à biota presente no corpo receptor (Zagatto et. al.1989; Rand, 1995; Romanelli, 2004).

Dentre as fontes difusas de aporte de contaminação na Bacia Hidrográfica do Rio Jundiaí estão os consultórios dentários, as atividades industriais e comércio da disposição de resíduos industriais transportados por caminhões tanques até a Estação de Tratamento de Esgoto (ETE) de Jundiaí. Tais resíduos chegam de diferentes pontos do Estado de São Paulo e até mesmo de fora do Estado, sob aprovação do órgão estadual de monitoramento ambiental, caracterizando uma transposição de resíduos inter-bacias hidrográficas. Fadini \& Lima (2007) destacam que nesse transito de resíduos, o lançamento de chorume proveniente de várias cidades, dentre as quais Paulínia, que recebe o resíduo sólido de diferentes cidades.

Estudos de outros locais sugerem uma abordagem ecotoxicológica mais ampla. Alegre et. al. (2008) avaliou a toxicidade do sedimento integral e elutriato utilizando o microcrustáceo Ceriodaphnia dubia e a toxicidade da água intersticial utilizando a bactéria Vibrio fischeri. Os resultados na Barragem da 
Ponte nova (Portinho) e nos pontos mais próximos da Barragem (Biritiba Mirim), pouca ou nenhuma toxicidade fora observada. Porém, os pontos mais distantes da barragem (após Mogi das Cruzes e até ETE de Suzano) apresentaram toxicidade expressiva para vários organismos-teste, possivelmente devido a aportes de contaminantes e matéria orgânica muito acima da capacidade de autodepuração do rio.

Em relação aos lodos gerados pela ETEs, Jonsson \& Maia (2007), avaliaram os efeitos tóxicos de lodos gerados nas ETEs de Barueri e Franca (SP), utilizando Daphnia similis e puderam observar valores de CE(i)50 acima de 90\%. Porém na ETE de Franca, levou-se cerca de 6 dias para atingir $80 \%$ de imobilidade, enquanto que na ETE de Barueri, cerca de 3 dias, concluindo que o lodo da ETE Barueri é mais tóxico, devendo-se, assim, ter mais cuidado ao usá-lo como condicionador de solos.

Dados da UNESCO asseguram que mais da metade dos rios do mundo encontram-se com elevado grau de poluição, assoreamento e perda de volume hídrico. Hoje, o desafio para a agricultura irrigada é contribuir para a produção e suprimento mundial de alimentos, por meio da utilização da água de forma eficiente, clara e integrada. Para 2025, a previsão é que a população mundial ultrapasse oito bilhões de habitantes. Perguntamos como abastecer e fornecer alimento a essa população de forma segura e equilibrada?

Ainda com relação ao rio Jundiaí, Neves (2006) analisou dados dispostos em diversos relatórios e levantamentos, para caracterizar o rio Jundiaí antes e, depois da construção da ETE Novo Horizonte, seus resultados mostraram que para a melhoria da qualidade do rio, há necessidade de uma gestão integrada, na qual todos os municípios devem investir e se esforçar para que haja recuperação do rio. 


\section{CONCLUSÃO}

- Foi demonstrada a toxicidade aguda na entrada da estação (chegada do emissário da cidade), e na calha que leva o efluente às lagoas de aeração (efluente da cidade + EVC). Em algumas campanhas foi encontrada toxicidade no efluente.

- Há impacto dos efluentes que chegam via caminhão na ETE em relação aos afluentes, pois há grande contribuição de carga orgânica e tóxica.

- Houve concordância entre as respostas apresentadas pelos dois organismos-teste, entretanto, a bactéria $V$. fischeri mostrou-se mais sensível que o microcrustáceo $D$. similis para todos os ensaios de toxicidade aguda.

- Praticamente não houve diferença entre os resultados de toxicidade das amostras a montante e a jusante do rio, porém não se pode desprezar o impacto que efluentes da ETE causam no rio devido à carga orgânica lançada e os compostos químicos residuais e seus subprodutos.

- A ETE Novo Horizonte apresentou boa eficiência tanto na redução da carga orgânica quanto na toxicidade. 


\section{ANEXOS}

Anexo 1 - Dados brutos dos ensaios de Ceriodaphnia dubia na campanha 2.

\begin{tabular}{|c|c|c|c|c|c|c|c|c|c|c|c|}
\hline Ponto & Data & R1 & R2 & R3 & R4 & R5 & R6 & R7 & R8 & R9 & R10 \\
\hline \multirow{5}{*}{ Controle } & $\begin{array}{c}24 / 10 / 20 \\
07\end{array}$ & 5 & 4 & 4 & 5 & 6 & 8 & 4 & 5 & 7 & 5 \\
\cline { 2 - 12 } & $\begin{array}{c}25 / 10 / 20 \\
07\end{array}$ & 6 & 5 & 7 & 4 & 6 & 5 & 3 & 7 & 5 & 6 \\
\cline { 2 - 12 } & $\begin{array}{c}26 / 10 / 20 \\
07\end{array}$ & 7 & 8 & 7 & 4 & 5 & 4 & 7 & 6 & 7 & 4 \\
\cline { 2 - 13 } & Total: & 18 & 17 & 18 & 13 & 17 & 17 & 14 & 18 & 19 & 15 \\
\hline
\end{tabular}

\begin{tabular}{|c|c|c|c|c|c|c|c|c|c|c|c|}
\hline Ponto & Data & R1 & $\mathrm{R} 2$ & R3 & $\mathrm{R} 4$ & R5 & R6 & R7 & R8 & R9 & R10 \\
\hline \multirow{4}{*}{$\begin{array}{c}\mathrm{P} 1 \\
\text { (montante } \\
\text { ) } 50 \%\end{array}$} & $\begin{array}{c}24 / 10 / 20 \\
07\end{array}$ & 2 & 4 & 4 & 3 & 5 & 2 & 3 & 0 & 7 & 4 \\
\hline & \begin{tabular}{|c|}
$25 / 10 / 20$ \\
07
\end{tabular} & 2 & 4 & 5 & 3 & 0 & 5 & 4 & 0 & 1 & 3 \\
\hline & \begin{tabular}{|c|}
$26 / 10 / 20$ \\
07
\end{tabular} & 3 & 5 & 6 & 4 & 2 & 3 & 4 & 0 & 4 & 0 \\
\hline & Total: & 7 & 13 & 15 & 10 & 7 & 10 & 11 & 0 & 12 & 7 \\
\hline
\end{tabular}

\begin{tabular}{|c|c|c|c|c|c|c|c|c|c|c|c|}
\hline Ponto & Data & R1 & $\mathrm{R} 2$ & R3 & $\mathrm{R} 4$ & R5 & $\mathrm{R} 6$ & R7 & R8 & R9 & R10 \\
\hline \multirow{4}{*}{$\begin{array}{c}\mathrm{P} 1 \\
\text { (montante } \\
\text { ) } 100 \%\end{array}$} & $\begin{array}{c}24 / 10 / 20 \\
07\end{array}$ & 0 & $x$ & 2 & 2 & 0 & 3 & 0 & 4 & $x$ & 3 \\
\hline & $\begin{array}{c}25 / 10 / 20 \\
07\end{array}$ & 0 & $x$ & 0 & 2 & 0 & 1 & 0 & 1 & $x$ & 3 \\
\hline & \begin{tabular}{|c|}
$26 / 10 / 20$ \\
07
\end{tabular} & 0 & $x$ & 1 & 4 & 0 & 2 & 1 & 3 & $x$ & 5 \\
\hline & Total: & 0 & 0 & 3 & 8 & 0 & 6 & 1 & 8 & 0 & 11 \\
\hline
\end{tabular}

\begin{tabular}{|c|c|c|c|c|c|c|c|c|c|c|c|}
\hline Ponto & Data & R1 & R2 & R3 & R4 & R5 & R6 & R7 & R8 & R9 & R10 \\
\hline \multirow{4}{*}{$\begin{array}{c}P 6 \\
\text { (jusante) } \\
50 \%\end{array}$} & $\begin{array}{c}24 / 10 / 20 \\
07\end{array}$ & 4 & 2 & 5 & 4 & 1 & 3 & 9 & 8 & 5 & 4 \\
\hline & $\begin{array}{c}25 / 10 / 20 \\
07 \\
\end{array}$ & 4 & 5 & 6 & 0 & 0 & 7 & 0 & 0 & 6 & 5 \\
\hline & $\begin{array}{c}26 / 10 / 20 \\
07 \\
\end{array}$ & 4 & 5 & 4 & 7 & 2 & 5 & 4 & 5 & 1 & 5 \\
\hline & Total: & 12 & 12 & 15 & 11 & 3 & 15 & 13 & 13 & 12 & 14 \\
\hline
\end{tabular}




\begin{tabular}{|c|c|c|c|c|c|c|c|c|c|c|c|}
\hline Ponto & Data & R1 & $\mathrm{R} 2$ & R3 & $\mathrm{R} 4$ & R5 & R6 & R7 & $\mathrm{R} 8$ & $\mathrm{R9}$ & $\mathrm{R} 10$ \\
\hline \multirow{4}{*}{$\begin{array}{c}\text { P6 } \\
\text { (jusante) } \\
100 \%\end{array}$} & $\begin{array}{c}24 / 10 / 20 \\
07\end{array}$ & 1 & 2 & 0 & 3 & 1 & 2 & 2 & 0 & 1 & 3 \\
\hline & \begin{tabular}{|c|}
$25 / 10 / 20$ \\
07
\end{tabular} & 3 & 2 & 0 & 3 & 4 & 3 & 4 & 4 & 3 & 4 \\
\hline & $\begin{array}{c}26 / 10 / 20 \\
07\end{array}$ & 4 & 5 & 3 & 3 & 2 & 4 & 0 & 5 & 2 & 5 \\
\hline & Total: & 8 & 9 & 3 & 9 & 7 & 9 & 6 & 9 & 6 & 12 \\
\hline
\end{tabular}

\begin{tabular}{|c|c|c|c|c|c|c|c|c|c|c|c|}
\hline Ponto & Data & R1 & R2 & R3 & R4 & R5 & R6 & R7 & R8 & R9 & R10 \\
\hline \multirow{5}{*}{ Controle } & $\begin{array}{c}24 / 10 / 20 \\
07\end{array}$ & 6 & 7 & 4 & 5 & 4 & 8 & 3 & 0 & 7 & 4 \\
\cline { 2 - 13 } & $\begin{array}{c}25 / 10 / 20 \\
07\end{array}$ & 7 & 3 & 5 & 7 & 6 & 7 & 6 & 7 & 4 & 6 \\
\cline { 2 - 13 } & $\begin{array}{c}26 / 10 / 20 \\
07\end{array}$ & 5 & 4 & 7 & 5 & 5 & 4 & 4 & 5 & 7 & 4 \\
\cline { 2 - 13 } & Total: & 18 & 14 & 16 & 17 & 15 & 19 & 13 & 12 & 18 & 14 \\
\hline
\end{tabular}

\begin{tabular}{|c|c|c|c|c|c|c|c|c|c|c|c|}
\hline Ponto & Data & R1 & $\mathrm{R} 2$ & R3 & $\mathrm{R} 4$ & $\mathrm{R} 5$ & R6 & R7 & R8 & $\overline{\mathrm{R} 9}$ & R10 \\
\hline \multirow{4}{*}{$\begin{array}{c}\text { P5 (saída } \\
2 \text { ETE) } \\
50 \%\end{array}$} & $\begin{array}{c}24 / 10 / 20 \\
07\end{array}$ & 6 & 3 & 6 & 6 & 5 & 3 & $x$ & 3 & 4 & 4 \\
\hline & $\begin{array}{c}25 / 10 / 20 \\
07\end{array}$ & 0 & 6 & 0 & 0 & 6 & 8 & $x$ & 8 & 7 & 6 \\
\hline & $\begin{array}{c}26 / 10 / 20 \\
07\end{array}$ & 10 & 2 & 7 & 10 & 0 & 5 & $x$ & 0 & 0 & 0 \\
\hline & Total: & 16 & 11 & 13 & 16 & 11 & 16 & 0 & 11 & 11 & 10 \\
\hline
\end{tabular}

\begin{tabular}{|c|c|c|c|c|c|c|c|c|c|c|c|}
\hline Ponto & Data & R1 & $\mathrm{R} 2$ & R3 & $\mathrm{R} 4$ & $\mathrm{R5}$ & $\mathrm{R} 6$ & R7 & R8 & R9 & R10 \\
\hline \multirow{4}{*}{$\begin{array}{l}\text { P5 (saída } \\
2 \text { ETE) } \\
100 \%\end{array}$} & $\begin{array}{c}24 / 10 / 20 \\
07\end{array}$ & $x$ & $x$ & $x$ & $x$ & $x$ & $x$ & $x$ & $x$ & $x$ & $x$ \\
\hline & \begin{tabular}{|c|}
$25 / 10 / 20$ \\
07
\end{tabular} & $x$ & $x$ & $x$ & $x$ & $x$ & $x$ & $x$ & $x$ & $x$ & $x$ \\
\hline & $\begin{array}{c}26 / 10 / 20 \\
07\end{array}$ & $x$ & $x$ & $x$ & $x$ & $x$ & $x$ & $x$ & $x$ & $x$ & $x$ \\
\hline & Total: & 0 & 0 & 0 & 0 & 0 & 0 & 0 & 0 & 0 & 0 \\
\hline
\end{tabular}

$\mathrm{X}$ - Morte do organismo

Anexo 2 - Dados brutos dos ensaios de Ceriodaphnia dubia na campanha 3.

\begin{tabular}{|c|c|c|c|c|c|c|c|c|c|c|c|}
\hline Ponto & Data & R1 & R2 & R3 & R4 & R5 & R6 & R7 & R8 & R9 & R10 \\
\hline Controle & $\begin{array}{c}31 / 3 / 200 \\
8\end{array}$ & 2 & 6 & 0 & 2 & 4 & 1 & 0 & $x$ & 1 & 2 \\
\cline { 2 - 12 } & $\begin{array}{c}2 / 4 / 200 \\
8\end{array}$ & 4 & 6 & 0 & 4 & 4 & 7 & 5 & x & 7 & 3 \\
\hline
\end{tabular}




\begin{tabular}{|c|c|c|c|c|c|c|c|c|c|c|c|}
\hline & $\begin{array}{c}4 / 4 / 200 \\
8\end{array}$ & 9 & 5 & 0 & 5 & 7 & 6 & 6 & $x$ & 8 & 6 \\
\cline { 2 - 12 } & Total: & 15 & 17 & 0 & 11 & 15 & 14 & 11 & 0 & 16 & 11 \\
\hline
\end{tabular}

\begin{tabular}{|c|c|c|c|c|c|c|c|c|c|c|c|}
\hline Ponto & Data & R1 & $\mathrm{R} 2$ & R3 & R4 & R5 & R6 & R7 & $\mathrm{R} 8$ & $\mathrm{R} 9$ & R10 \\
\hline \multirow{4}{*}{$\begin{array}{c}\mathrm{P} 1 \\
\text { (montante } \\
\text { ) } 50 \%\end{array}$} & $\begin{array}{c}31 / 3 / 200 \\
8\end{array}$ & $x$ & 0 & 2 & 1 & $x$ & 2 & 1 & 2 & 0 & 2 \\
\hline & \begin{tabular}{|c|c|}
$2 / 4 / 200$ \\
8 \\
\end{tabular} & $x$ & 5 & 3 & 6 & $x$ & 3 & 7 & 4 & 6 & 4 \\
\hline & \begin{tabular}{|c|}
$4 / 4 / 200$ \\
8
\end{tabular} & $x$ & 12 & 13 & 8 & $x$ & 5 & 7 & 9 & 12 & 8 \\
\hline & Total: & 0 & 17 & 18 & 15 & 0 & 10 & 15 & 15 & 18 & 14 \\
\hline
\end{tabular}

\begin{tabular}{|c|c|c|c|c|c|c|c|c|c|c|c|}
\hline Ponto & Data & R1 & $\mathrm{R} 2$ & R3 & R4 & R5 & R6 & R7 & R8 & $\mathrm{R} 9$ & R10 \\
\hline \multirow{4}{*}{$\begin{array}{c}\text { P1 } \\
\text { (montante } \\
\text { ) } 100 \%\end{array}$} & $\begin{array}{c}31 / 3 / 200 \\
8\end{array}$ & 2 & $x$ & $x$ & 0 & 2 & 1 & $x$ & 2 & 1 & 1 \\
\hline & \begin{tabular}{|c|}
$2 / 4 / 200$ \\
8 \\
\end{tabular} & 3 & $x$ & $x$ & 8 & 4 & 3 & $x$ & 5 & 6 & 5 \\
\hline & \begin{tabular}{|c|}
$4 / 4 / 200$ \\
8
\end{tabular} & 4 & $x$ & $x$ & 16 & 7 & 3 & $x$ & 10 & 6 & 7 \\
\hline & Total: & 9 & 0 & 0 & 24 & 13 & 7 & 0 & 17 & 13 & 13 \\
\hline
\end{tabular}

\begin{tabular}{|c|c|c|c|c|c|c|c|c|c|c|c|}
\hline Ponto & Data & R1 & R2 & R3 & R4 & R5 & R6 & R7 & R8 & R9 & R10 \\
\hline \multirow{5}{*}{ Controle } & $\begin{array}{c}31 / 3 / 200 \\
8\end{array}$ & 0 & 0 & 1 & 3 & 1 & 1 & 0 & 0 & 0 & 2 \\
\cline { 2 - 14 } & $\begin{array}{c}2 / 4 / 200 \\
8\end{array}$ & 0 & 0 & 8 & 5 & 4 & 5 & 9 & 6 & 5 & 6 \\
\cline { 2 - 14 } & $\begin{array}{c}4 / 4 / 200 \\
8\end{array}$ & 0 & 0 & 11 & 6 & 9 & 7 & 8 & 7 & 0 & 7 \\
\cline { 2 - 14 } & Total: & 0 & 0 & 20 & 14 & 14 & 13 & 17 & 13 & 5 & 15 \\
\hline
\end{tabular}

\begin{tabular}{|c|c|c|c|c|c|c|c|c|c|c|c|}
\hline Ponto & Data & $\mathrm{R} 1$ & $\mathrm{R} 2$ & R3 & R4 & R5 & R6 & $\mathrm{R} 7$ & R8 & R9 & R10 \\
\hline \multirow{4}{*}{$\begin{array}{l}\text { P4 (saída } \\
\text { 1) } 50 \%\end{array}$} & $\begin{array}{c}31 / 3 / 200 \\
8 \\
\end{array}$ & 3 & 0 & 4 & 4 & 1 & 0 & 5 & 0 & 1 & 4 \\
\hline & \begin{tabular}{|c|}
$2 / 4 / 200$ \\
8
\end{tabular} & 5 & 0 & 5 & 4 & 3 & 9 & 5 & 0 & 6 & 2 \\
\hline & \begin{tabular}{|c|}
$4 / 4 / 200$ \\
8
\end{tabular} & 2 & 0 & 1 & 0 & 4 & 1 & 0 & 0 & 1 & 2 \\
\hline & Total: & 10 & 0 & 10 & 8 & 8 & 10 & 10 & 0 & 8 & 8 \\
\hline
\end{tabular}

\begin{tabular}{|c|c|c|c|c|c|c|c|c|c|c|c|}
\hline Ponto & Data & R1 & $\mathrm{R} 2$ & R3 & R4 & R5 & R6 & R7 & R8 & R9 & R10 \\
\hline \multirow[t]{3}{*}{\begin{tabular}{|l|} 
P4 (saída \\
1) $100 \%$
\end{tabular}} & $\begin{array}{c}31 / 3 / 200 \\
8\end{array}$ & 4 & 3 & 4 & 3 & 3 & 8 & 0 & 5 & 1 & 6 \\
\hline & \begin{tabular}{|c|}
$2 / 4 / 200$ \\
8
\end{tabular} & 4 & 6 & 5 & 4 & 6 & 2 & 5 & 4 & 6 & 4 \\
\hline & \begin{tabular}{|l|}
$4 / 4 / 200$ \\
\end{tabular} & 1 & 0 & 0 & 1 & 1 & 1 & 2 & 1 & 2 & 3 \\
\hline
\end{tabular}




\begin{tabular}{|c|c|c|c|c|c|c|c|c|c|c|c|}
\hline & 8 & & & & & & & & & & \\
\cline { 2 - 12 } & Total: & 9 & 9 & 9 & 8 & 10 & 11 & 7 & 10 & 9 & 13 \\
\hline
\end{tabular}

\begin{tabular}{|c|c|c|c|c|c|c|c|c|c|c|c|}
\hline Ponto & Data & R1 & R2 & R3 & R4 & R5 & R6 & R7 & R8 & R9 & R10 \\
\hline \multirow{5}{*}{ Controle } & $\begin{array}{c}31 / 3 / 200 \\
8\end{array}$ & 2 & 1 & 0 & 1 & 1 & 1 & 5 & 3 & 2 & 4 \\
\cline { 2 - 13 } & $\begin{array}{c}2 / 4 / 200 \\
8\end{array}$ & 7 & 10 & 12 & 9 & 7 & 8 & 12 & 10 & 6 & 8 \\
\cline { 2 - 13 } & $\begin{array}{c}4 / 4 / 200 \\
8\end{array}$ & 7 & 9 & 7 & 7 & 9 & 4 & 12 & 9 & 17 & 10 \\
\cline { 2 - 13 } & Total: & 16 & 20 & 19 & 17 & 17 & 13 & 29 & 22 & 25 & 22 \\
\hline
\end{tabular}

\begin{tabular}{|c|c|c|c|c|c|c|c|c|c|c|c|}
\hline Ponto & Data & R1 & $\mathrm{R} 2$ & R3 & R4 & R5 & R6 & R7 & R8 & R9 & R10 \\
\hline \multirow{4}{*}{$\begin{array}{c}\text { P6 } \\
\text { (Jusante) } \\
50 \%\end{array}$} & $\begin{array}{c}31 / 3 / 200 \\
8\end{array}$ & 1 & 3 & 6 & 0 & 2 & 0 & 0 & 2 & 2 & 2 \\
\hline & $\begin{array}{c}2 / 4 / 200 \\
8 \\
\end{array}$ & 7 & 5 & 8 & 5 & 6 & 3 & 8 & 4 & 4 & 9 \\
\hline & \begin{tabular}{|c|}
$4 / 4 / 200$ \\
8
\end{tabular} & 7 & 8 & 10 & 19 & 5 & 14 & 7 & 7 & 8 & 13 \\
\hline & Total: & 15 & 16 & 24 & 24 & 13 & 17 & 15 & 13 & 14 & 24 \\
\hline
\end{tabular}

\begin{tabular}{|c|c|c|c|c|c|c|c|c|c|c|c|}
\hline Ponto & Data & R1 & $\mathrm{R} 2$ & R3 & R4 & R5 & R6 & R7 & R8 & R9 & R10 \\
\hline \multirow{4}{*}{$\begin{array}{l}\text { P4 (saída } \\
\text { 1) } 100 \%\end{array}$} & $\begin{array}{c}31 / 3 / 200 \\
8\end{array}$ & 0 & 3 & $x$ & 2 & 1 & 1 & 0 & 0 & 0 & 0 \\
\hline & \begin{tabular}{|c|}
$2 / 4 / 200$ \\
8
\end{tabular} & 4 & 3 & $x$ & 7 & 5 & 7 & 15 & 5 & 9 & 7 \\
\hline & \begin{tabular}{|c|}
$4 / 4 / 200$ \\
8 \\
\end{tabular} & 8 & 8 & $x$ & 7 & 10 & 11 & 7 & 11 & 10 & 9 \\
\hline & Total: & 12 & 14 & 0 & 16 & 16 & 19 & 22 & 16 & 19 & 16 \\
\hline
\end{tabular}

Anexo 3 - Dados brutos dos ensaios de Ceriodaphnia dubia na campanha 4.

\begin{tabular}{|c|c|c|c|c|c|c|c|c|c|c|c|}
\hline Ponto & Data & R1 & R2 & R3 & R4 & R5 & R6 & R7 & R8 & R9 & R10 \\
\hline \multirow{5}{*}{ Controle } & \begin{tabular}{c}
$7 / 7 / 2007$ \\
\cline { 2 - 14 }
\end{tabular} & 3 & 4 & 3 & 6 & 3 & 4 & 4 & 4 & 5 & 6 \\
\cline { 2 - 13 } & $\begin{array}{c}8 / 7200 \\
0\end{array}$ & 5 & 6 & 4 & 6 & 4 & 7 & 4 & 8 & 6 & 3 \\
\cline { 2 - 12 } & 08 & 7 & 6 & 7 & 5 & 6 & 6 & 5 & 7 & 6 & 7 \\
\cline { 2 - 13 } & Total: & 15 & 16 & 14 & 17 & 13 & 17 & 13 & 19 & 17 & 16 \\
\hline
\end{tabular}

\begin{tabular}{|c|c|c|c|c|c|c|c|c|c|c|c|}
\hline Ponto & Data & R1 & R2 & R3 & R4 & R5 & R6 & R7 & R8 & R9 & R10 \\
\hline $\begin{array}{c}\text { P1 } \\
\text { (montante }\end{array}$ & $7 / 7 / 2007$ & 9 & 9 & 2 & 6 & 1 & 0 & 2 & 5 & 1 & 3 \\
\hline
\end{tabular}




\begin{tabular}{|c|c|c|c|c|c|c|c|c|c|c|c|}
\hline \multirow{3}{*}{) $50 \%$} & 8 & & & & & & & & & & \\
\cline { 2 - 13 } & $\begin{array}{c}10 / 7 / 20 \\
08\end{array}$ & 6 & 7 & 9 & 8 & 7 & 7 & 2 & 6 & 8 & 5 \\
\cline { 2 - 15 } & Total: & 15 & 16 & 16 & 14 & 15 & 11 & 8 & 17 & 14 \\
\hline
\end{tabular}

\begin{tabular}{|c|c|c|c|c|c|c|c|c|c|c|c|}
\hline Ponto & Data & R1 & $\mathrm{R} 2$ & R3 & R4 & R5 & R6 & R7 & R8 & R9 & R10 \\
\hline \multirow{4}{*}{$\begin{array}{c}\text { P1 } \\
\text { (montante } \\
\text { ) } 100 \%\end{array}$} & $7 / 7 / 2007$ & 5 & 5 & 5 & 0 & 2 & 1 & 8 & 3 & 3 & $x$ \\
\hline & \begin{tabular}{|c|}
$8 / 7 / 200$ \\
8
\end{tabular} & 0 & 0 & 6 & 5 & 6 & 3 & 0 & 4 & 6 & $x$ \\
\hline & $\begin{array}{c}10 / 7 / 20 \\
08 \\
\end{array}$ & 5 & 7 & 9 & 6 & 8 & 10 & 9 & 5 & 6 & $x$ \\
\hline & Total: & 10 & 12 & 20 & 11 & 16 & 14 & 17 & 12 & 15 & 0 \\
\hline
\end{tabular}

\begin{tabular}{|c|c|c|c|c|c|c|c|c|c|c|c|}
\hline Ponto & Data & R1 & $\mathrm{R} 2$ & R3 & R4 & R5 & R6 & R7 & R8 & R9 & R10 \\
\hline \multirow{4}{*}{$\begin{array}{l}\text { P4 (saída } \\
\text { 1) } 50 \%\end{array}$} & $7 / 7 / 2007$ & 7 & 7 & 2 & 9 & 2 & 9 & 2 & 4 & 2 & 4 \\
\hline & \begin{tabular}{|c|}
$8 / 7 / 200$ \\
8
\end{tabular} & 7 & 0 & 4 & 0 & 7 & 0 & 6 & 5 & 6 & $x$ \\
\hline & \begin{tabular}{|c|}
$10 / 7 / 20$ \\
08
\end{tabular} & 4 & 11 & 5 & 9 & 7 & 11 & 8 & 6 & 7 & $x$ \\
\hline & Total: & 18 & 18 & 11 & 18 & 16 & 20 & 16 & 15 & 15 & 4 \\
\hline
\end{tabular}

\begin{tabular}{|c|c|c|c|c|c|c|c|c|c|c|c|}
\hline Ponto & Data & R1 & $\mathrm{R} 2$ & R3 & R4 & R5 & R6 & R7 & $\mathrm{R} 8$ & R9 & R10 \\
\hline \multirow{4}{*}{$\begin{array}{l}\text { P4 (saída } \\
\text { 1) } 100 \%\end{array}$} & $7 / 7 / 2007$ & $x$ & 1 & 1 & 2 & 2 & 0 & 0 & $x$ & 0 & 1 \\
\hline & \begin{tabular}{|c|}
$8 / 7 / 200$ \\
8
\end{tabular} & $x$ & 3 & 2 & 5 & 4 & 5 & 5 & $x$ & 0 & 2 \\
\hline & \begin{tabular}{|c|}
$10 / 7 / 20$ \\
08
\end{tabular} & $x$ & 0 & 8 & 5 & 7 & 6 & 9 & $x$ & 0 & 5 \\
\hline & Total: & 0 & 4 & 11 & 12 & 13 & 11 & 14 & 0 & 0 & 8 \\
\hline
\end{tabular}

\begin{tabular}{|c|c|c|c|c|c|c|c|c|c|c|c|}
\hline Ponto & Data & $\mathrm{R} 1$ & $\mathrm{R} 2$ & $\mathrm{R} 3$ & $\mathrm{R} 4$ & $\mathrm{R} 5$ & $\mathrm{R} 6$ & $\mathrm{R} 7$ & $\mathrm{R} 8$ & $\mathrm{R} 9$ & $\mathrm{R} 10$ \\
\hline \multirow{5}{*}{ Controle } & $7 / 7 / 2007$ & 4 & $\mathrm{x}$ & $\mathrm{x}$ & 7 & 6 & 8 & 9 & 7 & 6 & 7 \\
\cline { 2 - 13 } & $\begin{array}{c}8 / 7 / 200 \\
8\end{array}$ & 6 & $\mathrm{x}$ & $\mathrm{x}$ & 7 & 5 & 6 & 1 & 3 & 5 & 5 \\
\cline { 2 - 12 } & $\begin{array}{c}10 / 7 / 20 \\
08\end{array}$ & 5 & $\mathrm{x}$ & $\mathrm{x}$ & 7 & 5 & 7 & 5 & 12 & 5 & 8 \\
\cline { 2 - 12 } & Total: & 15 & 0 & 0 & 21 & 16 & 21 & 15 & 22 & 16 & 20 \\
\hline
\end{tabular}

\begin{tabular}{|c|c|c|c|c|c|c|c|c|c|c|c|}
\hline Ponto & Data & R1 & $\mathrm{R} 2$ & R3 & R4 & R5 & R6 & R7 & R8 & R9 & R10 \\
\hline \multirow{4}{*}{$\begin{array}{l}\text { P5 (saída } \\
\text { 2) } 50 \%\end{array}$} & $7 / 7 / 2007$ & 4 & 4 & 9 & 9 & 11 & 10 & 8 & 4 & 5 & $x$ \\
\hline & \begin{tabular}{|c|}
$8 / 7 / 200$ \\
8
\end{tabular} & 2 & 5 & 9 & 8 & 7 & 0 & 7 & $x$ & $x$ & $\mathrm{x}$ \\
\hline & \begin{tabular}{|c|}
$10 / 7 / 20$ \\
08 \\
\end{tabular} & $x$ & $x$ & 1 & $x$ & 3 & 2 & 7 & $x$ & $x$ & $x$ \\
\hline & Total: & 6 & 9 & 19 & 17 & 21 & 12 & 22 & 4 & 5 & 0 \\
\hline
\end{tabular}

\begin{tabular}{|c|c|c|c|c|c|c|c|c|c|c|c|}
\hline Ponto & Data & R1 & R2 & R3 & R4 & R5 & R6 & R7 & R8 & R9 & R10 \\
\hline $\begin{array}{c}\text { P5 (saída } \\
\text { 2) } 100 \%\end{array}$ & $\begin{array}{c}7 / 7 / 2007 \\
8 / 7 / 200 \\
8\end{array}$ & 10 & 5 & 9 & 2 & 0 & 1 & 0 & 5 & 4 & 4 \\
\hline
\end{tabular}




\begin{tabular}{|c|c|c|c|c|c|c|c|c|c|c|c|}
\hline & $\begin{array}{c}10 / 7 / 20 \\
08\end{array}$ & 1 & 3 & 0 & $x$ & $x$ & $x$ & $x$ & 3 & $x$ & $x$ \\
\cline { 2 - 19 } & Total: & 11 & 17 & 18 & 5 & 0 & 1 & 0 & 8 \\
\hline
\end{tabular}

\begin{tabular}{|c|c|c|c|c|c|c|c|c|c|c|c|}
\hline Ponto & Data & $\mathrm{R} 1$ & $\mathrm{R} 2$ & R3 & $\mathrm{R} 4$ & $\mathrm{R} 5$ & R6 & R7 & R8 & R9 & R10 \\
\hline \multirow{4}{*}{$\begin{array}{c}\mathrm{P6} \\
\text { (montante } \\
\quad 50 \%\end{array}$} & $2 / 1 / 1900$ & 0 & 6 & 3 & $x$ & 3 & $x$ & 5 & 8 & 3 & 3 \\
\hline & \begin{tabular}{|c|}
$8 / 7 / 200$ \\
8
\end{tabular} & 7 & 7 & 0 & $x$ & 0 & $x$ & 0 & 8 & 0 & 8 \\
\hline & $\begin{array}{c}10 / 7 / 20 \\
08 \\
\end{array}$ & 5 & 7 & 10 & $x$ & 6 & $x$ & 9 & 10 & 9 & 7 \\
\hline & Total: & 12 & 20 & 13 & 0 & 9 & 0 & 14 & 26 & 12 & 18 \\
\hline
\end{tabular}

\begin{tabular}{|c|c|c|c|c|c|c|c|c|c|c|c|}
\hline Ponto & Data & R1 & $\mathrm{R} 2$ & R3 & R4 & R5 & R6 & R7 & $\mathrm{R} 8$ & R9 & R10 \\
\hline \multirow{4}{*}{$\begin{array}{c}\mathrm{P6} \\
\text { (montante } \\
\text { ) } 100 \%\end{array}$} & $2 / 1 / 1900$ & $x$ & $x$ & $x$ & 8 & 6 & $x$ & 3 & $x$ & 5 & $x$ \\
\hline & \begin{tabular}{|c|}
$8 / 7 / 200$ \\
8
\end{tabular} & $x$ & $x$ & $x$ & 8 & 6 & $x$ & $X$ & $x$ & 8 & $x$ \\
\hline & $\begin{array}{c}10 / 7 / 20 \\
08\end{array}$ & $x$ & $x$ & $x$ & 7 & 9 & $x$ & $X$ & $x$ & 10 & $x$ \\
\hline & Total: & 0 & 0 & 0 & 23 & 21 & 0 & 3 & 0 & 23 & 0 \\
\hline
\end{tabular}




\section{REFERÊNCIAS BIBLIOGRÁFICAS}

ABNT NBR 12713 Ecotoxicologia Aquática - Toxicidade aguda - Método de Ensaio com Daphnia spp ( Cladocera, Crustácea). ABNT,31/05/2004.

ABNT NBR 13373 Ecotoxicologia Aquática - Toxicidade crônica - Método de Ensaio com Ceriodaphnia ssp ( Cladocera, Crustácea). ABNT,30/03/2005.

ABNT NBR 15411-2 Ecotoxicologia Aquática - Determinação de efeito inibitório de amostras de água sobre a emissão de luz de Vibrio fischeri (Ensaio de bactéria luminescente) Parte 2: Método utilizando bactérias desidratadas. ABNT 18/09/2006.

ALEGRE, G.F.; MATTIOLO, S.R.; BORRELY, S.I. Avaliação ecotoxicológica em sedimento do rio Tietê entre Salesópolis e Suzano, São Paulo. In: X CONGRESSO BRASILEIRO DE ECOTOXICOLOGIA, 2008, São Paulo. p 199.

ALEM SOBRINHO, P. Estudos para a fixação de parâmetros para o rio Jundiaí no trecho classe IV, visando atender as condições de jusante. 1976. Tese (Mestrado) - Faculdade de Saúde Pública - USP, São Paulo.

AZEVEDO, F.A.; CHASIN, A.A.M. As bases toxicológicas da ecotoxicologia. São Carlos. Editora Rima. 2006. 322p.

BAILEY, H.C.; KRASSOI, R.; ELPHICK, J.R.; MULHALL, ANN-MAREE; HUNT, P.; TEDMANSON, L; LOVELL, A. Whole effluent toxicity of sewage treatment plants in the Hawkesbury-Nepean Watershed, New South Wales, Australia, to Ceriodaphnia dubia and Selenastrum capricornutum. Environ. Toxicology and Chemistry, v.19(1), p. 72-81. 2000.

BERTOLETTI, E.; GHERRARDI-GOLDSTEIN, E.; NIPPER, M.G. Toxicidade de efluentes industriais na Grande São Paulo. Revista DAE, v.49, N.155, p.63-70, 1989.

BILA, D.M. Degradação e remoção da atividade estrogênica do desregulador endócrino 17ß-estradiol pelo processo de ozonização. Tese (Doutorado) Universidade Federal do Rio de Janeiro - UFRJ, Rio de Janeiro.

BIRGE, W.J.; BLACK, J.A.; WESTERMAN, A.G. Short-term fish and amphibian tests for determining the effects of toxicant stress on early life stages and estimating chronic values for single compounds and complex effluents. 1985. Environmental toxicology and chemistry. 49: 807 - 821. 
BORRELY, S.I. Tratamento de esgoto sanitário com o uso de acelerador de elétrons. 1995. Tese (Mestrado) - Instituto de Pesquisas Energéticas e Nucleares - USP, São Paulo.

BORRELY, S. I. Avaliação de redução da toxicidade de efluentes tratados por irradiação com feixe de elétrons, por meio de testes de toxicidade aguda. 2001. Tese (Doutorado) - Instituto de Pesquisas Energéticas e Nucleares - USP, São Paulo.

BRAGA, B., HESPANHOL, I., CONEJO, J.G.L. Introdução à engenharia ambiental. São Paulo. Prenhall. 2005. 336p.

BRANCO, S. M. Hidrologia aplicada à engenharia sanitária. São Paulo, CETESB ASCETESB, $3^{\text {a }}$ ed., 1986.640 p.

BRASIL. Avaliação de impacto na saúde das ações de saneamento: marco conceitual e estratégia metodológica. Organização Pan-Americana da Saúde. Brasília: Ministério da Saúde, 2004. 116 p.

BRITO-PELEGRINI, N.N.; PATERNIANI, J.E.S.; PELEGRINI, R. Água para consumo, um bem limitado. Site <www.ceset.unicamp.br/lte> 2005 - site visitado no dia 04/04/2007.

BULICH, A.A. A practical and reliable method for monitoring the toxicity of aquatic samples. Process. Biochem. March/ April, 45-47, 1982.

CAETANO, I.; ANTUNES, M. A linguagem das bactérias . Revista Ciência Hoje, São Paulo, p16, maio 2003.

CARVAlHO, A.R., OLIVEIRA, M.V.C, Principios básicos do Saneamento do meio. São Paulo. Editora SENAC. 2008. 212p.

CETESB (Companhia de Tecnologia de Saneamento Ambiental). Relatório de Qualidade de Águas Interiores do Estado de São Paulo - 1993. São Paulo: Relatório Técnico.

CETESB (Companhia de Tecnologia de Saneamento Ambiental). Relatório de Qualidade de Águas Interiores do Estado de São Paulo - 2000. São Paulo: Relatório Técnico.

CETESB (Companhia de Tecnologia de Saneamento Ambiental). Relatório de Qualidade de Águas Interiores do Estado de São Paulo - 2001. São Paulo: Relatório Técnico.

CETESB (Companhia de Tecnologia de Saneamento Ambiental). Relatório de Qualidade de Águas Interiores do Estado de São Paulo - 2003. São Paulo: Relatório Técnico. 
CETESB (Companhia de Tecnologia de Saneamento Ambiental). Relatório de Qualidade de Águas Interiores do Estado de São Paulo - 2004. São Paulo: Relatório Técnico.

CETESB (Companhia de Tecnologia de Saneamento Ambiental). Relatório de Qualidade de Águas Interiores do Estado de São Paulo - 2005. São Paulo: Relatório Técnico.

CETESB (Companhia de Tecnologia de Saneamento Ambiental). Relatório de Qualidade de Águas Interiores do Estado de São Paulo - 2006. São Paulo: Relatório Técnico.

CETESB (Companhia de Tecnologia de Saneamento Ambiental). Relatório de Qualidade de Águas Interiores do Estado de São Paulo - 2007. São Paulo: Relatório Técnico.

CETESB. Levantamento de surfactantes encontrados no meio aquático. Revista Ambiente. v. 1, n 1, 1991.

CETESB. Métodos para a avaliação da toxicidade de poluentes a organismos aquáticos. São Paulo. v.1, 1997.

CONSELHO NACIONAL DO MEIO AMBIENTE. Resolução CONAMA $n^{\circ} 357$. (DOU 18.03.2005).

CSJ, 2009 - Companhia de Saneamento de Jundiaí. Site $<$ www.saneamento.com.br> Acesso em 2009

DACACH, N.G. Saneamento básico. São Paulo. Ed. Didática e científica Itda.. 1990.

DAE, 2006. Infra-estrutura da ETE. Site <http://www.daejundiai.com.br/daesite/portal.nsf/V03.02/infraEstrutura_ete_apres entacao?OpenDocument. > Acesso em 2006.

DAE, 2009 - DAE Água e Esgoto S/A. Site < www.daejundiai.com.br>. Acesso em Março de 2009.

DATASUS. 2006. Site < http://tabnet.datasus.gov.br> acesso em 2009.

D'ISEP, M.S.P.; DA COSTA, T.C.; MATSUMOTO, S.T.; DA SILVA, A.B.; SIQUEIRA, L.; ADDAD, J.E.: Avaliação ecotoxicológica de amostras ambientais contaminadas com combustíveis derivados de petróleo, após atendimento emergencial, por meio do teste com Vibrio fischeri. X Congresso Brasileiro de Ecotoxicologia. Abril 2008. p 110.

DUARTE, C.L. Aplicação do processo avançado de oxidação por feixe de elétrons na degradação de compostos orgânicos presentes em efluentes industriais. 1999. Tese (Doutorado) Instituto de pesquisas energéticas e nucleares - USP - São Paulo. 
Ellouze, M.; Saddoud, A.; Dhouib, A.; Sayadi, S. Assessment of the impact of excessive chemical additions to municipal wastewaters and comparison of three technologies in the removal performance of pathogens and toxicity.Micro. Res. 164. 138-148. 2009

FADINI, P. S.; LIMA, F. A. Comportamento Redox do Mercúrio no Rio Jundiaí SP: Aspectos do Ciclo Redox. In: 30a Reunião anual da Sociedade Brasileira de Química 2007.

FESB - CETESB. 1971. Estudos efetuados na represa de Americana e no trecho do Rio Atibaia, a montante do reservatório. Relatório técnico, São Paulo. 66p.

FUNASA. Cianobacterias tóxicas na água para consumo humano. Brasilia: Ministério da saúde: Fundação Nacional de saúde. 2003. 51p.

GERARDI-GOLDSTEIN, E., Testes de toxicidade em efluentes industriais. Ambiente, v.2-1, p.33-37. 1998.

GERARDI-GOLDSTEIN, E.; ZAGATTO, P.A.; ARAÚJO, R.P.A.; BETOLETTI, E. Avaliação da toxicidade dos principais despejos industriais da região da ERQSuzano, através de ensaios biológicos. Revista DAE (132), São Paulo, p.42-48. 1983.

GHERARDI-GOLDSTEIN,E. E COLABORADORES. Estimativa da carga poluidora de efluentes industriais da região de Cubatão através de ensaios biológicos com microcrustáceos e peixes. In: Congresso Brasileiro de Engenharia Sanitária e Ambiental, 13. Maceió, AL. 1985,10p. 13.

GRAMOLELLI, JR. F.; MIRANDA, J. R.; CUNHA, C.; MATSURA.; Bacia do Rio Jundiaí; 1 ed.; 2006; 144p.

Hamada, N. Ensaios de toxicidade empregados na avaliação de efeitos no sistema de tratamento de esgotos e efluentes, ETE Suzano, e seu entorno, utilizando organismos aquáticos. 2008. Tese (Mestrado) - Instituto de Pesquisas Energéticas e Nucleares - USP, São Paulo.

HAMILTON, M.A.; RUSSO, R.C.;THURSTON,R.V.(1977). Trimmed SpearmanKarber method for estimating median lethal concentrations in toxicity bioassays. Environmental Science and Technology, 11(7): 714-719.

IBGE, Fundação; Sinopse preliminar do censo demográfico. Rio de Janeiro: IBGE, 2000, v. 7.

IBGE. Censo 2007. Site < http://www.ibge.gov.br> acesso em 2009.

JONSSON, C.M.; MAIA., A.H.N. Avaliação da toxicidade do lodo de esgoto de duas estações de tratamento para o invertebrado aquático Daphnia similis. Pesticidas. r. ecotoxicol. e meio ambiente, Curitiba, v. 17, jan./dez. 2007. 
KNIE, J.L.W.; LOPES, E.W.B. Testes Ecotoxicológicos - Métodos, técnicas e aplicações - Cooperação Técnica Alemã com a Fundação do Meio Ambiente de Santa Catarina, 2005.

LEANDRO-ALVES, C.; BISO, S.C; QUITERIO, G.M.; OLIVEIRA-NETO, A.L.; REGANHAN-CONEGLIAN, C.M.: Ecotoxicidade Aguda de Detergentes Líquidos de Uso Doméstico e de Uso Laboratorial Para o Organismo-Teste Daphnia similis. X Congresso Brasileiro de Ecotoxicologia. Abril 2008. p 212.

LIKENS, G. E. The ecosystem approach: its use and abuse. Oldenhorf/Luhe: Germany: Ecology Institute, 1992. 166p.

McKEAN, W. Pulp and paper industry. In: Guthrie, F.E. \& Perry, J. Introduction to Environmental Toxicology. Horth Holland, Elservier, 1980. Cap 16, p.210-24.

MENDONÇA, S. R. Lagoas de Estabilização e Aeradas Mecanicamente: Novos Conceitos. João Pessoa, 1990. Sindicato Nacional dos Editores de Livros, RJ.

Mendonça, E.; Picado, A.; Paixão, S.M.; Silva, L.; Cunha, M.A.; Leitão, S.; Moura, I.; Cortez, C.; Brito F. Ecotoxicity tests in the environmental analysis of wastewater treatment plants: Case study in Portugal. Jor. Har. Mat. 163. 665-670. 2009.

MOUNT, D.I.; STEEN, A.E.; NORBERG-KING, T.J. The validity of effluent and ambient toxicity tests for predicting biological impact Back river, Baltimore Harbor, Maryland.1986. EPA/600/8-86/001.

NATURE NEWS. EUA divulgam relatório de contaminação da água potável. 2009

NEVES, M.A.; CARDOSO, M.S.N. Qualidade das águas do rio Jundiaí (SP): A necessidade de uma gestão integrada. HOLOS Environment v.6 n.2, 2006 - P.91.

NIPPER, M.G.; ROPER D. S.; WILLIAMS, E.K.; MARTINS, M.L.; VAN DAN, L.; MILLS, G.N. Sediment toxicity and benthic communities in mildly contaminated mudflats. Environ. Toxic. And Chem. V.17(3), p. 502-510, 1998.

OPAS (2001) Água e Saúde. Relatório. Site www.opas.org.br/sistema/fotos/agua.pdf. Acesso em 2009.

PEREIRA, D. N.; GOLDSTEIN, E.G.; ZAGATTO, P.A.; SASSI, R. Bioensaios: um programa a serviço do controle de poluição. Resultados Iniciais. Revista Ambiente, v.1, n.1, p.32-36, 1987.

Phillippi Jr. A. Saneamento, Saúde e Ambiente: Fundamentos para um desenvolvimento sustentável. São Paulo. Editora Manole. 2005. 850p.

PIVELI, R.P.; KATO, M.T. Qualidade das águas e Poluição: Aspectos FísicoQuímicos. ABES - Associação Brasileira de Engenharia Ambiental. $1^{a}$ Edição. 2006. 
RACHID, B.R.F.S; ABESSA, E.C.P.M., ZARONI, L.P. Ecotoxicidade dos efluentes de esgotos domésticos lançados por emissários submarinos na baixada santista, SP. Proc. Do VI Enc. De Ecotoxicologia. São Carlos, 3-6 setembro de 2000 p.115.

RAND, G. M.; WELLS, P. G.; MCCARTY, L. S.; Introduction to Aquatic Toxicology. In: RAND, G. M. Fundamentals of Aquatic Toxicology: Effects, Environmental Fate and Risk Assessment. Washington, D. C., Taylor \& Francis, $2^{\circ} \mathrm{Ed}, \mathrm{p} .3-67,1995$.

Rebouças, A. C.; Riccomini, C.; Ellert, N.; Duarte, U.; Mellito, K.M.; Senf, L. A. \& Souza, J. C. S. Diagnóstico hidrogeológico da Região Metropolitana de São Paulo - RMSP: uso e proteção, Anais $8^{\circ}$ Cong. ABAS, p. 93-102, Recife, 1994.

ROCHA, J.C., ROSA, A.H., CARDOSO, A.A. Introdução à química ambiental. Porto Alegre . Editora Bookman. 256p. 2009.

ROMANELLI, M. F.; Avaliação da toxicidade aguda e crônica dos surfactantes DSS e LAS submetidos à irradiação com feixes de elétrons. 2004. Tese (Mestrado) - Instituto de Pesquisas Energéticas e Nucleares - USP, São Paulo.

ROMANELLI, M. F.; MORAES, M.C.F.; VILLAVICENCIO, A.L.C.H.; BORRELY, S.I. Evaluation of toxicity reduction of sodium dodecyl sulfate submitted to electron beam radiation. Radiat. Phys. Chem., v.71, p. 411-413, 2004.

SABESP. Tratamento de água. Site <http:www.sabesp.com.br>. Acesso em 2009.

Saneamento Ambiental. 2009. Saneamento Ambiental OnLine $n^{\circ} 395$ - 13/4/2009 site < http://www.sambiental.com.br> acesso em 2009.

SÃO PAULO. Conselho Estadual de Recursos Hídricos. Comitê das Bacias Hidrográficas dos Rios Piracicaba, Capivari e Jundiaí. Relatório de situação dos recursos hídricos das bacias dos rios Piracicaba, Capivari e Jundiaí: Relatório um. Piracicaba. 2004.

SAPIA, P.M.A.; MORITA, D.M. Critérios de recebimento de efluentes não domésticos em sistemas públicos de esgotos: uma análise crítica. Revista de Engenharia Sanitária e Ambiental, Vol. 8 - No 3 - jul/set 2003, 145-156.

SEADE. Municípios, por tipo de Tratamento Dispensado ao Esgoto, segundo Unidades de Gerenciamento de Recursos Hídricos. Site < http://www.seade.gov.br>. Acesso em 2009.

Secretaria de Saúde do município de Jundiaí. 2005. Site < http://www.jundiai.sp.gov.br> acesso em 2009.

SLATERRY G.G. Toxics reduction evaluation. Case-study-operations \& management view point (Lesson Learned) PATAPSCO WWTP. Proc. Virginia WPCA, ARL 134-188. 1988. 
SODRÉ, F.F.; MONTAGNER, C.C.; LOCATELLI, M.A.F.; JARDIM, W.F. Ocorrência de interferentes endócrinos e produtos farmacêuticos em águas superficiais da região de Campinas (SP, Brasil). J. Braz. Soc. Ecotoxicol. 2: 187 196.

TUNDISI, J.G.; TUNDISI, T.M.; PARESCHI, D.C.P.; LUZIA A.P.; VON HAELING, P.H.; FROLLINI, E.H. A bacia hidrográfica do Tietê/Jacaré: estudo de caso em pesquisa e gerenciamento. Estud. av. , São Paulo, v. 22, n. 63, 2008 .

UNIAGUA (Universidade da Água). Água no Planeta. Site <www.uniagua.org.br>. Acesso em 05 set. 2006.

VILLEGAS-NAVARRO, A.; GONZPALEZ, M.C.R.; LÓPEZ, E.R. Evaluation of Daphnia magna as na indicator of toxicity and treatment efficacy of textile wastewaters. Environ. Internat., v.25, n.5, p. 619-624, 1999.

ZAGATtO, P. A.; GOLDSteIN, E. G. Toxicidade em Águas do Estado de São Paulo. Revista CETESB de Tecnologia: Ambiente, v. 5, p. 13 - 20, 1991.

ZAGATTO, P.A. \& BERTOLETTI, E. Ecotoxicologia Aquática - princípios e aplicações. São Carlos. Editora Rima. 2006. 464p.

ZAGATTO, P.A.; Bertoletti, E.; Goldstein, E.G.; Souza, H.B. Avaliação de Toxicidade em Sistema de Tratamento Biológico e afluentes líquidos. Revista Sabesp, N. 166, Jul/ago 1992. 